\title{
Neogene and early Pleistocene flora from Alaska, USA and Arctic/Subarctic Canada: New data, intercontinental comparisons and correlations
}

\author{
T.L. Fletcher, A. Telka, N. Rybczynski, and J.V. Matthews, Jr.
}

\begin{abstract}
A new correlation scheme primarily concerning macro- and meso-floral remains of bryophytes and vascular plants from 26 Neogene sites and over 50 florules in Alaska and northern Canada is presented. Flora are valuable for correlating Arctic Neogene sites, especially where absolute dating methods are not possible. These taxa clearly differentiate Neogene from Quaternary deposits in the North American Arctic. Recent age estimates provided using terrestrial cosmogenic nuclide (TCN) dating provide tiepoints for these correlations and tend to confirm earlier dates achieved by relative and correlative methods. Our knowledge of North American Arctic/Subarctic palaeofloras and faunas is sufficiently detailed to allow inter-regional comparisons. This paper contains the first attempt to compare and contrast Neogene and early Pleistocene macroand meso-floras from the entire circum-Arctic region. The subfossil and fossil floras are valuable for understanding the evolution of the boreal realm, from the qualitatively different composition of the communities of the Neogene Arctic, to those of the more southerly modern boreal region. These differences may be due to the warm climate of the Neogene Arctic combined with the long dark of polar winter - a phenomenon with no modern analogue. The differences highlight the need for a comprehensive understanding of species' ecology to predict species ranges under near-future climate conditions analogous to our Neogene past. Many sites described here present rich opportunities for future cross-disciplinary study, including research related to the role of warm-climate intervals in patterning past and present Arctic ecosystems.
\end{abstract}

T.L. Fletcher. Key Laboratory of Forest Ecology and Management, Institute of Applied Ecology, Chinese Academy of Sciences, Shenyang, Liaoning 110164, China and College of Forestry and Conservation, University of Montana, Missoula, Montana 59812, United States of America. drtlfletcher@gmail.com A. Telka. PALEOTEC Services - Quaternary and late Tertiary plant macrofossil and insect fossil analyses, 1-574 Somerset St. West, Ottawa, Ontario K1R 5K2, Canada.

N. Rybczynski. Department of Palaeobiology, Canadian Museum of Nature, Ottawa, Ontario K1P 6P4,

Fletcher, T.L., Telka, A., Rybczynski, N., and Matthews, J.V., Jr. 2021. Neogene and early Pleistocene flora from Alaska, USA and Arctic/Subarctic Canada: New data, intercontinental comparisons and correlations. Palaeontologia Electronica, 24(1):a08. https:// doi.org/10.26879/1121

palaeo-electronica.org/content/2021/3274-arctic-macroflora

Copyright: February 2021 Palaeontological Association.

This is an open access article distributed under the terms of Attribution-NonCommercial-ShareAlike 4.0 International (CC BY-NC-SA 4.0 ), which permits users to copy and redistribute the material in any medium or format, provided it is not used for commercial purposes and the original author and source are credited, with indications if any changes are made.

creativecommons.org/licenses/by-nc-sa/4.0/ 
Canada.nrybczynski@nature.ca and Department of Biology and Department of Earth Sciences, Carleton University, Ottawa, Ontario K1S 5B6, Canada. nrybczynski@gmail.com

J.V. Matthews, Jr. 1 Cricket Lane, Hubley, Nova Scotia B3Z 1A5, Canada.

Keywords: biostratigraphy; correlation; Neogene; Pleistocene; Arctic; palaeoflora

Submission: 20 August 2020. Acceptance: 1 January 2021.

\section{INTRODUCTION}

This article addresses palaeofloral macroand meso-remains (herein referred to as macroflora as opposed to palynomorphs) in Neogene environments and biostratigraphy in the North American Arctic. It may be read in concert with a sister-paper focusing on arthropods of the same time-span and region (Matthews et al., 2019). The collaborations that fostered these large works had their origins in joint workshops and field programs of Canadian, US American, and Russian scientists during the late 1980s and early 1990s, that aimed to generate a synthesis of circum-Arctic Neogene climate and environments. Two important steps toward this objective were publication of special issue volumes on the subject (Arctic, v 43, no. 4 and Quaternary International, v22/23). Twenty-five years later this paper and its sibling take the next steps toward completing the projected series of reviews, with at least one further article in review (Barendregt, personal commun. 2020).

In the first of the above special volumes, Matthews and Ovenden (1990) reviewed the macroflora from several sites around the North American Arctic. In the 30 years since, significant new discoveries have been made and many sites and localities have revised taxonomic lists or new dating. Moreover, our understanding of the evolution of the Arctic basin changed. This paper intends to not only update the earlier work of Matthews and Ovenden (1990), but also present new regional correlations and comparisons with flora from Arctic Russia and Greenland.

Among the floras discussed here are several from sites that are independently dated by radiometric methods and palaeomagnetic analyses. These are keystone sites that provide the fixed chronological points needed for correlation of the Neogene of Arctic/Subarctic North America. The macroflora from such sites are the ones that have the greatest potential value for dating and correlation of sites that are not independently dated, like many of the sites we discuss here.

Since this project's conception in 1987, the perceived value of these floras and faunas has only increased. The mid-Pliocene Warm Period (mPWP) in particular is of interest to climate modelers as our nearest analogue for near future warming with atmospheric $\mathrm{CO}_{2}$ levels comparable to modern (Haywood et al., 2016). During mPWP, mean annual surface temperatures were between 3 and $4^{\circ} \mathrm{C}$ warmer globally, and multiproxy analysis suggests an astounding $14-22^{\circ} \mathrm{C}$ warmer in the North American Arctic (Fletcher et al., 2017). Current climate models appear to underestimate the Arctic temperature amplification during the MPWP (Dowsett et al., 2012) yet accurately predict recent observed Arctic temperature amplification $\left(1.36^{\circ} \mathrm{C} /\right.$ century in the Arctic vs $0.79{ }^{\circ} \mathrm{C} /$ century for the averaged Northern Hemisphere; Bekryaev et al., 2010). These floras represent a valuable resource for understanding our Earth system's response to global warmth and may contribute to other outstanding questions in polar research.

\section{METHODS}

Appendix 1 is a collated and updated version of previously published macrofloral taxa lists (Matthews and Ovenden, 1990). Appendix 2 is a zipped file of tables in spreadsheet format available for downloading. The locations from which the floras come include localities in Alaska, the Canadian Arctic Archipelago, northern Yukon, and the northern mainland of the Northwest Territories (NWT). The term 'florule' is used here informally to denote the macrofloral remains from specific levels or horizons at a single site. The term 'flora' generally refers to a collection of florules, either from the same site or from different sites in the same region. The numbers used here (in the text, figures and appendix) refer to a flora, and do not reflect site, field, or sample numbers. Similar lists for arthropods, using the same numbering scheme, were provided in Matthews et al. (2019). The floral remains considered here include material that is mistakable for modern organic material in terms of its preservation, and thus although 'fossil' is sometimes used, many of the floras are subfossil materi- 
als preserved in the permafrost rather than materials that have undergone 'fossilisation'.

Unless otherwise indicated, vascular plant taxa were identified by the authors (AT and JVM). Bryophytes were identified by L.E. Ovenden and others as noted. Identifications of the vascular plant remains, consisting mostly of seeds and fruits, are based on comparison with modern reference material in the Geological Survey of Canada seed and fruit reference collection (This collection is identified for transfer to the Canadian Museum of Nature in the near future.), illustrations in various publications (particularly Russian), and with the help and advice of various specialists on Neoegene macrofloras from North America and northern Europe. A valuable aid in identification of some of plant parts has been the study of degraded and transported seeds and fruits from modern alluvium, lacustrine deposits, and various types of mires and swamps (e.g., Taxodium swamps from southeastern USA).

Many of the vascular plant taxa, are referred only to the generic level or tentatively ('cf.' = bold face text in Appendix 1) to the species level. It is highly probable, in view of the existence of the Bering Land Bridge during the Neogene and occurrence of obvious Asian taxa in these North American assemblages that many of the taxa listed here have already been found in some of the rich Russian palaeofloras. Many new species have been described from collections at those sites. This means that definitive identifications must await comparison with Russian type specimens. Until such time as that is done we refrain from describing new taxa in order to avoid further complicating an already overburdened nomenclature (Tiffney, 1981). There are, however, a few fossils for which the specific identity is obvious. This is true for many of the bryophyte fossils, the majority of which cannot be distinguished from extant species (Matthews and Ovenden, 1990). Some of the fossils are too poorly preserved for a definite identification, even to the generic level. In the appendix these are indicated by an underlined site code number.

\section{COMMENTS ON SELECTED LOCALITIES AND FLORAS}

The localities and palaeoflora discussed below include most that were treated in Matthews and Ovenden (1990). They are treated again here because in some cases their remains have taken on new significance or new and potentially significant taxa have been identified. Also mentioned below are several floras that have not previously been discussed. The taxa mentioned in the discussion of each flora are some of the ones having intriguing modern distributions or represent unusual and often unexpected taxa.

\section{Lava Camp Mine (Alaska)}

The flood-plain alluvium at Lava Camp mine on the Seward Peninsula, Alaska (Figure 1, Flora 1 ) is $\mathrm{K}-\mathrm{Ar}$ dated by an overlying $5.7 \pm 0.2 \mathrm{Ma}$ (late Miocene) lava (Hopkins et al., 1971), since recalibrated to $5.9 \pm 0.2 \mathrm{Ma}$ (Turner et al., 1980), and is thus considered to fall within the Messinian Age (White et al., 1997a). This means that the plants and animals from the deposit lived at a time shortly before the first marine breach of the Bering Land Bridge between 4.8 and 5.6 Ma (Gladenkov et al., 2002). Wolfe (1994) concluded that the Lava Camp floral assemblage represented a 'High Coastal Mixed Coniferous' forest, based on its general physiognomy. Lava Camp is considered a keystone site as it contains identified arthropods and macroflora and is independently dated. Based on the beetle fauna, a climate mutual range method found the mean temperature of the warmest month (Tmax-mean) to be $12.8^{\circ} \mathrm{C}$, and mean temperature of the coldest month (Tmin-mean) to be $-23.1^{\circ} \mathrm{C}-$ only $\sim 1.3^{\circ} \mathrm{C}$ warmer than today (Elias and Matthews, 2002).

One of the Lava Camp taxa most useful for the correlation of the Arctic sites is tentatively identified as Paliurus (Rhamnaceae); in part because it is found in some Russian floras (Dorofeev, 1972), as well as the North American Arctic. The macroremains of this taxon are also easily distinguished, adding to its value for correlation (Matthews and Ovenden, 1990, figure 8b; Ager et al., 1994, figures 4-1 and 4-2).

\section{Lost Chicken Mine (Alaska)}

The upper pit at the Lost Chicken mine in east central Alaska (Figure 2; Flora 2) has produced a diverse palaeo-assemblage including macroflora (Matthews et al., 2003), pollen (White et al., 1999) and a few, but very significant, bones of a horse (Porter, 1988; A. Sher, personal commun., 1992). As per Lava Camp, it is considered a keystone site due to the rich palaeofloral and arthropod remains both above and below the Lost Chicken tephra, dated at $2.9 \pm 0.4 \mathrm{Ma}$ (Matthews et al., 2003).

The Lost Chicken sediments contain seeds of the plant Epipremnum crassum C. \& E. Reid (Araceae; Appendix 1; Figure 3), important due to their presence and preservation across many High Arctic sites. In Matthews et al. (2003), the Epiprem- 


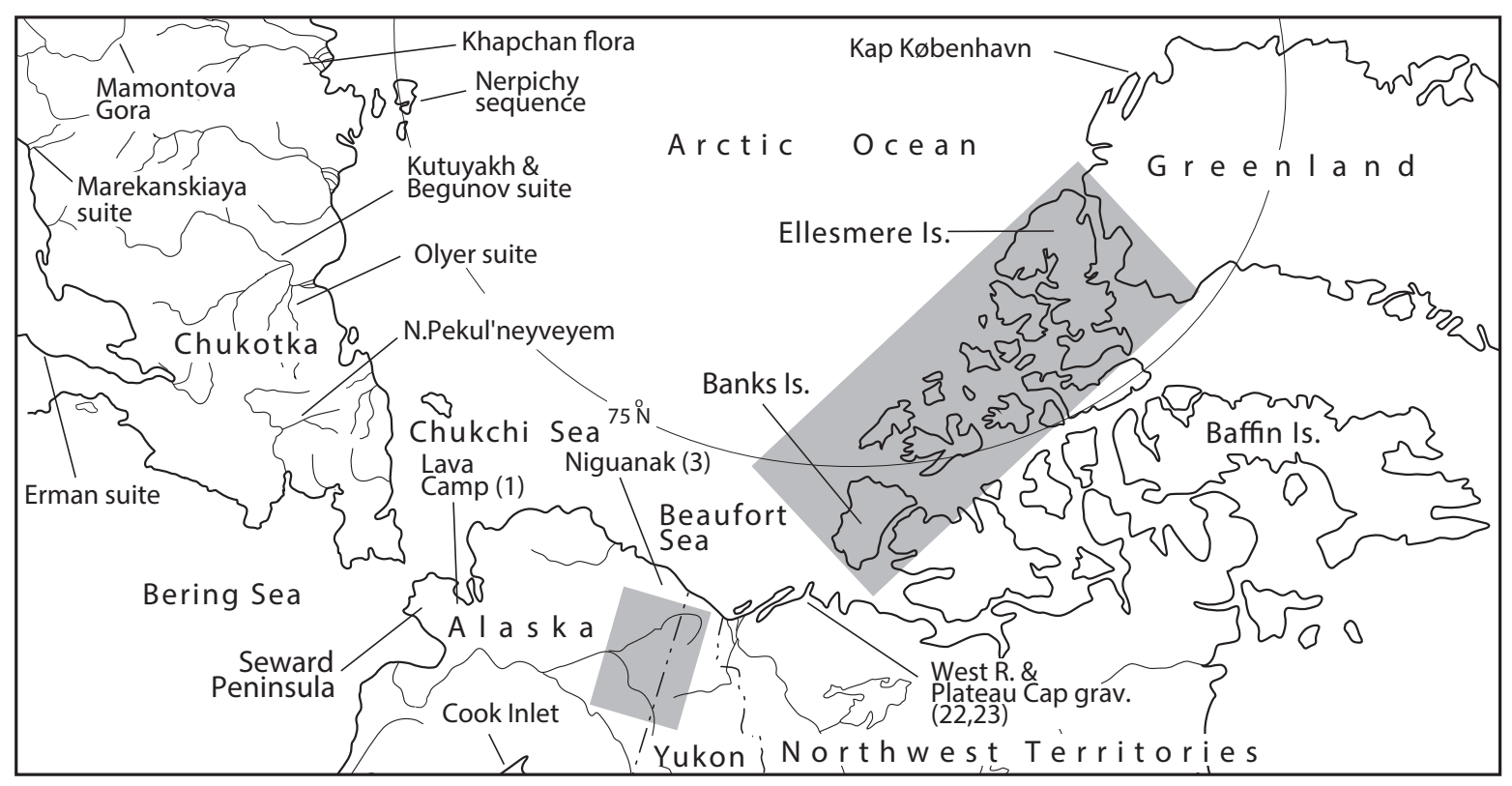

FIGURE 1. Distribution of sites and geographical features mentioned in the text. Siberian localities are from Baranova and Biske (1979). Shaded areas are shown in greater detail in Figures 2 and 4 . Numbers refer to site codes used in Appendix 1 and throughout this paper.

num seeds are stated to be associated with the Fortymile tephra that occurs in the upper pit of the Lost Chicken exposure at that section (station 91-3 in Matthews et al., 2003). However, the present status of the Fortymile tephra has been questioned (Westgate, personal commun., 2011), and it may not be different from Lost Chicken tephra. Unfortunately, this uncertainty will probably never be resolved because samples of the Fortymile tephra are lost, and the Lost Chicken exposure has been destroyed. Matthews revisited the site in 2011 in an attempt to relocate ash associated with Epipremnum fossils. The section had been changed markedly by mining and neither the critical Fortymile tephra nor the Lost Chicken tephra were seen. The way in which the site was being mined in 2011 and the miner's plans for development probably means the exposure will no longer be valuable for palaeontology. All that can be said is that the occurrence of Epipremnum at Lost Chicken occurs only beneath Fortymile tephra in the upstream part of the section (station 91-3 in Matthews et al., 2003) and if the Fortymile tephra and Lost Chicken tephra are the same, then E. crassum was growing in this region approximately $3 \mathrm{Ma}$. Also, because the Lost Chicken Epipremnum seeds are well preserved, they must represent plants which grew at or near the site of deposition.

Lost Chicken, like many Neogene sites in Alaska and Canada, contained seeds of a species

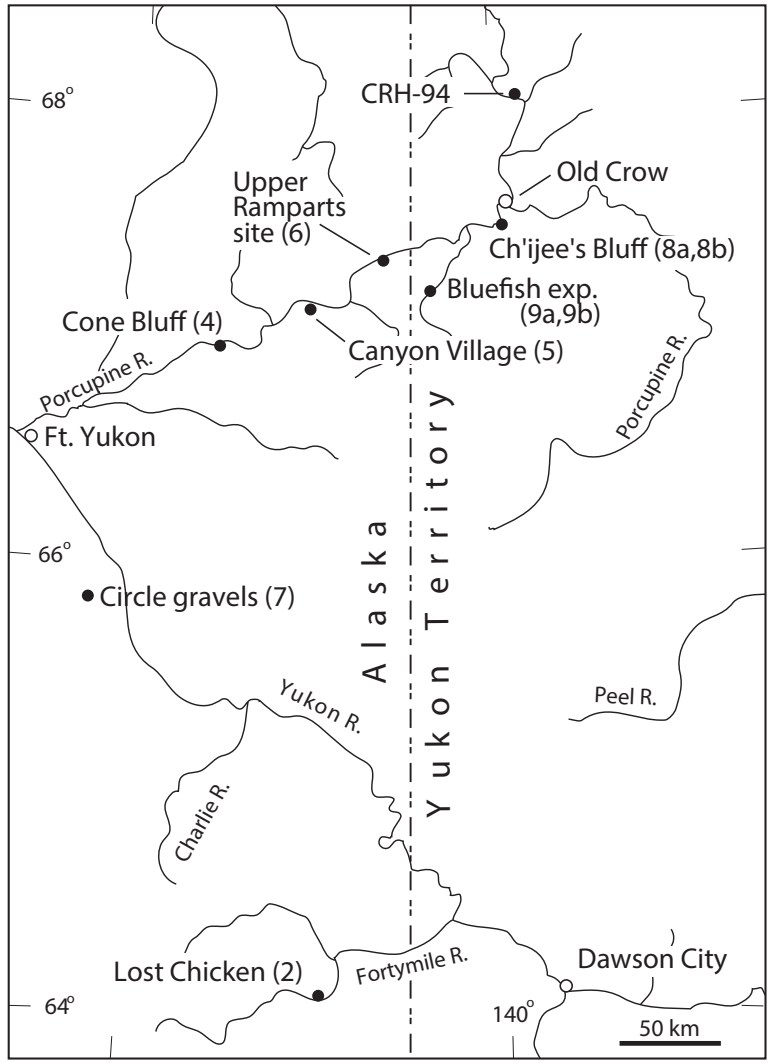

FIGURE 2. Detailed site location maps of sites from interior Alaska and the Yukon. Numbers beside sites refer to site codes used in Appendix 1 and throughout this paper. 


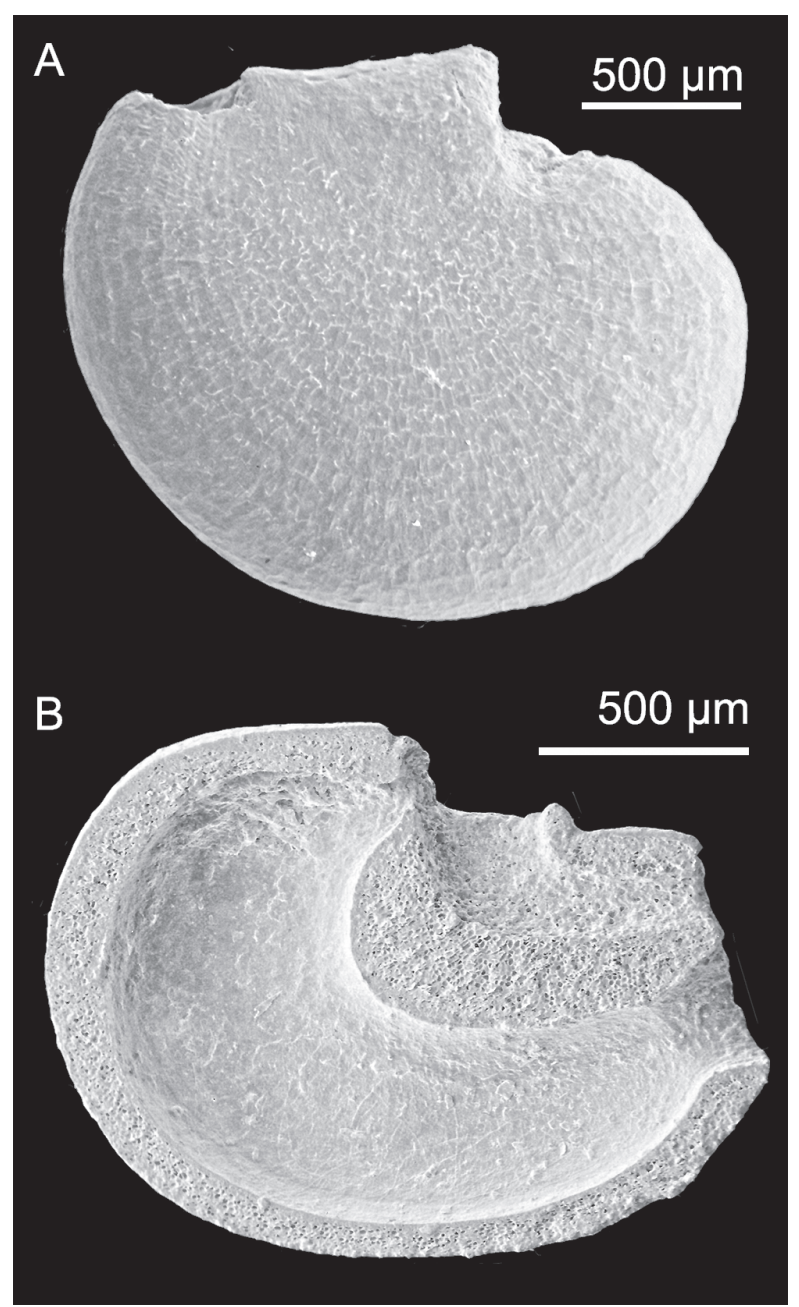

FIGURE 3. SEM micrographs of Epipremnum from Banks Island. (A) Epipremnum seed, external view, Ballast Brook, "lower Beaufort Lignite", GSC 108847; (B) Epipremnum seed, internal view, Ballast Brook Formation, lower member, Sample 2, GSC 141420.

of Myrica closely related to modern sweet gale (Myrica gale L.). However, the best preserved of the Lost Chicken endocarps retain the lateral lobes, which happen to be much longer than those of M. gale. Similar well-preserved specimens of Myrica occur at other sites (e.g., figure 6h, Matthews et al., 1990b). In previous discussions of these distinctive fossils, they were referred to 'Myrica eogale type', because of their similarity to that species as described and illustrated in publications on Neogene floras from Siberia. Bennike (1990) discovered fossils that appear to be $M$. eogale Nikit. in latest Pliocene deposits at Kap København, Greenland (Figure 1) and described them as the new species $M$. arctogale Benn. Myrica arctogale and $M$. eogale may be the same wide-ranging species, but such a decision must wait until Russian type material is examined. In the meantime, because one of us (JVM) has seen specimens which Bennike described and not $M$. eogale types from Russia, the most appropriate name to use for fossils from Lost Chicken and all others previously referred to $M$. eogale, is $M$. arctogale. Specimens which do not preserve complete lateral lobes are simply named $M$. (gale) in Appendix 1. A study of the wood from Lost Chicken (Wheeler and Arnette, 1994) identified Picea and Larix.

The Lost Chicken flora indicates a rich boreal forest with Asian affinities consistent with ongoing exchange across Beringia after the initial opening of the Bering Strait (Gladenkov et al., 2002). The temperature estimate from mutual climate range of beetles is Tmax-mean of $13.8^{\circ} \mathrm{C}, 1.5^{\circ} \mathrm{C}$ colder than present, and Tmin-mean $-23.1,2.3^{\circ} \mathrm{C}$ warmer than present, (Elias and Matthews, 2002).

\section{Circle Gravels (Alaska)}

High level alluvium is exposed in road cuts and gravel pits near Circle, Alaska (Figure 2; Flora 7; Williams, 1962). The pollen flora suggests an Early to mid-Pliocene age (Ager et al., 1994). Conifer needle fragments and leaves include taxa that are typical of Pliocene deposits elsewhere in the region: Sambucus, cf. Paliurus, Epipremnum, Weigela, Decodon, and Pinus subsection Strobus with medial resin canals (Cembrae in Ager et al., 1994). Detailed analysis of cones from the deposits determined that they were all Larix or Picea. The Larix was described as a new species (Larix circlensis Miller \& Ping) with affinities to the extant European larch L. decidua Mill. (Miller and Ping, 1994). The spruce was indistinguishable from modern North American Picea glauca (Moench) Voss in Graebner (1907). Examination of the wood revealed Picea and Larix, in keeping with the cones (Wheeler and Arnette, 1994).

\section{Upper Ramparts (Alaska)}

Near the Alaska/Yukon border (Figure 2; Flora 6 ) the Porcupine River flows through a canyon where, in places, peats and forest beds are interbedded with flood basalts of mid-Miocene age (Brosgé and Reiser, 1969; Plumley and Vance, 1988; Fouch et al., 1994). Specifically, Organic Beds 3 and 4 have been dated by ${ }^{40} \mathrm{Ar} / 39 \mathrm{Ar}$ to $15.2 \pm 0.1 \mathrm{Ma}$ (Kunk et al., 1994). White and Ager (1994) gave a detailed discussion of the palynology of the site and White et al. (1997a) discussed its age compared to other Miocene sites. 
The plant macrofossils listed in Matthews and Ovenden (1990) were collected during an earlier study and their exact provenience is in question, though they most probably come from sediments equivalent to either Organic Beds 2 or 3, e.g., upper part of Unit A or middle of Unit B of Fouch et al. (1994). Among the more significant fossils from the original sample are seeds of Epipremnum crassum, Aldrovanda, and Hypericum. In the previous discussion of the site (Matthews and Ovenden, 1990) it was stated that the Upper Ramparts record of Aldrovanda was the only one for North America. Since then, seeds of this now temperate and tropical aquatic plant have been found in two other North American Arctic floras, both of them presumed to be of mid-Miocene age (Floras 11a, 22, see Appendix 1; Fyles et al., 1994).

At one site (90-1e) finely laminated organic sediments similar to gyttja yielded leaves of Metasequoia and Comptonia (Wolfe, personal commun., 1991) as well as seeds of Epipremnum crassum, Aracites globosa (C. \& E. Reid) Benn., Betula, Menyanthes, Decodon gibbosus Nikit. type and leaf fragments of the east Asian conifer Glyptostrobus. A felted peat and organic silt within Organic Bed 4 also yielded well-preserved E. crassum seeds, some of them found in groups or clusters, as well as seeds of Aracites, and Glyptostrobus leaf fragments. The Epipremnum seeds possess the scaly and delicate black epidermis that is seldom seen on Epipremnum seeds from alluvial deposits. As is the case at Lost Chicken, this type of preservation probably means that the Bed 4 seeds are from plants that grew at the site.

Analysis of the wood found Pinus (Strobus) in Unit A (sensu Fouch et al., 1994), and either Sequoia or Metasequoia in Unit B. Wheeler and Arnette (1994) noted that macrofossils of both have been found in the region.

White and Ager (1994) used pollen from the various organic beds to draw palaeoclimatic conclusions. Organic Bed 3 represents peak warmth from the site, which was likely deposited during the mid-Miocene Climatic Optimum (Zachos et al., 2008), with mean annual temperature of about $9^{\circ} \mathrm{C}$ and a warm month mean temperature greater than $20^{\circ} \mathrm{C}$. Cold month mean temperature may have been slightly below $0^{\circ} \mathrm{C}$.

\section{Canyon Village (Porcupine River, Alaska)}

Downstream on the Porcupine River from the Upper Ramparts, on the upstream end of Fish Hook Bend, near the abandoned settlement of
Canyon Village, is a series of bluffs (Figure 2; Flora $5)$. These bluffs expose late Miocene lake sediments ('Mud Unit C' of Fouch et al., 1994), overlain unconformably by Neogene and Quaternary alluvium (Brosgé et al., 1966; Thorson and Dixon, 1983). Lacustrine sediments predominate at the upstream site (90-7) while the downstream site $(90-8)$ contains some sandy beds. A late Miocene tephra, dated at $6.4 \mathrm{Ma}$, occurs at both sites (Fouch et al., 1994; Kunk et al., 1994), and this means the deposition of these sediments probably occurred just before the episode of regional erosion documented in McNeil et al. (2001).

Pollen and plant macrofossils from the Canyon Village sites are currently unpublished (Ager, personal commun., 2020); however, a report by White et al. (1997b) that includes the pollen count data showed that the late Miocene of the Porcupine plateau was characterized by diverse coniferous forests that lacked many of the hardwoods found in the mid-Miocene deposits of the Upper Ramparts.

Some of the more important plant macrofossils are fruits of water chestnut (Trapa), these being the most northerly record for this Asian plant in North America, as well as needles of Douglas fir (Pseudotsuga), at least four types of pine, and seeds that are very similar to those of the subtropical aquatic plant Caldesia.

\section{Ch'ijee's Bluff (Porcupine River, Northern Yukon)}

Ch'ijee's Bluff is a section along the Porcupine River that exposes material deposited from the Pliocene through the Holocene (Figure 2; Flora 8a and $8 \mathrm{~b}$; McKown et al., 2002). It comprises six units (Matthews et al., 1990a), the lower two of which are late Neogene, while Unit 3 is less well constrained. Unit 1 contains large concretions of iron-cemented alluvial sand, whereas Unit 2 is substantially less consolidated quartz-rich alluvial sand with coarse organic detrital horizons (Matthews and Ovenden, 1990). This and the unconformity between Units 1 and 2 may be evidence of a hiatus of considerable time. The pollen of Unit $1 \mathrm{com}-$ pares with Pliocene sites in the northern Yukon, some of which are dated via tephra layers (Westgate et al., 1995), suggesting an age between 2.5 and $5 \mathrm{Ma}$. Unit 2 contains only scant pollen and macrofossil data.

Two studies of the wood from Unit 1 (Wheeler and Arnette, 1994; McKown et al., 2002) described a forest diverse in conifers, a sharp contrast to the spruce and rare larch today. These woods include 
beaver-cut Abies, larch, spruce, Pinus subsection Strobus type (Pinus monticola Douglas ex D.Don in Lambert (1832)), and a new species, Pinus matthewsii McKown et al., which is similar to the extant $P$. contorta Douglas ex Loudon. Studies of cones confirmed Larix aff. L. omolica-altoborealis complex, Picea (aff. P. glauca), and both Pinus (Strobus) subsection Strobus and Pinus (Pinus) subsection Contortae. Schorn (1994) also described fossil wood displaying features characteristic of frost damage at the top of Unit 2. Remains of the extinct plant Aracites globosa occur in the upper part of Unit 2 (Flora 8b), which suggests that the unit is no younger than early Pleistocene (Aalto and Hirvas, 1987; Klassen et al., 1988). A study of the alpha-cellulose in Pinaceae wood from the site revealed a climate similar-to-modern for that region (Porter, 2014).

\section{Bluefish Exposure (Bluefish River near Porcupine River, Yukon Territory)}

The Bluefish Exposure is located on the Bluefish River, which empties into the Porcupine River between the village of Old Crow, Yukon, and the Canada/Alaska border (Figure 2; figure 6 of Matthews and Ovenden, 1990). Much of the exposure comprises channel sediments deposited during the Quaternary (McCourt, 1982; Zazula et al., 2004). This unit is inset into older sediments having a lignitic zone approximately $1 \mathrm{~m}$ thick resting on dolomite that is topped by $11 \mathrm{~m}$ of silt containing several prominent layers of detrital organics. The sample from the basal lignite zone (Flora 9a) contains a few poorly preserved plant macrofossils, such as nuts of Prunus, and needle fragments with medial resin canals from Pinus subsection Strobus (previously, Pinus subsection Cembrae sensu Engelmann, 1880). Markedly richer are the wellpreserved fossils from the detrital organics approximately $6 \mathrm{~m}$ higher in the section (Flora 9b). In this sample elderberry (Sambucus) is represented by its nuts, and Epipremnum crassum seeds are frequent.

Previously (Matthews and Ovenden, 1990), Flora 9a was thought to be much older than Flora $9 \mathrm{~b}$. And yet, the presence of numerous well-preserved Epipremnum crassum seeds in $9 \mathrm{~b}$ means that is no younger than late Pliocene. A more definite conclusion on age must await palaeomagnetic or cosmogenic analyses. The nearby Cone Bluff locality (Matthews and Ovenden, 1990) also contains $E$. crassum and is possibly the same age as the Bluefish exposure.
The temperature estimate from mutual climate range of beetles is Tmax-mean of $13.3^{\circ} \mathrm{C}$, which is $2.7^{\circ} \mathrm{C}$ warmer than present, and Tmin-mean $-24.5^{\circ} \mathrm{C}$, or $4.5^{\circ} \mathrm{C}$ warmer than present, (Elias and Matthews, 2002).

\section{West River Deposits and Plateau Cap Gravels (Horton River area, Northwest Territories)}

The record from the Anderson Basin includes several localities that contain Neogene deposits (Dixon et al., 1992). Some deposits were originally identified as interglacial (Matthews et al., 1990b), however subsequent sampling of the Plateau Cap gravels (Flora 23), upland near the Horton River, revealed cones very similar to the extinct Larix groenlandi Benn. This shows that the beds from Matthews et al. (1990b) were Gelasian (early Pleistocene) or older, although they are still considered younger than the West River Beds (Flora 22).

The lower pre-glacial gravels were tentatively assigned to the Pliocene and correlated to the Beaufort Formation discussed below (Vincent, 1990). Matthews and Ovenden (1990) demonstrated the gravels and organics at one of the sites (West River, Flora 22) are more likely mid-Miocene, i.e., of approximately the same age as the Ballast Brook Formation (Fyles et al., 1994). For example, like the Mary Sachs Gravel on southern Banks Island, they contain fossils of such exotic plants as Actinidia (kiwi) and extinct forms with doubtful modern affinities, such as Microdiptera/ Mneme type. Most Miocene deposits discussed here lack insect fossils. As with the Ballast Brook locality discussed below, the sequence at West River may further define climatic conditions prior to and immediately after the period of regional erosion documented by McNeil et al. (2001) and thought to be caused by the Messinian event. Other deposits throughout the Anderson Basin are of several different ages and may span much of the Neogene. This region is a promising site for future investigations.

\section{Northern Banks Island - Ballast Brook (Northwest Territories)}

Banks Island is a key region for study of the Neogene in the Canadian Arctic because it contains deposits of two demonstrably different ages. One group is represented by the mid-Miocene Ballast Brook Formation at Ballast Brook on the northwest side of the island (Figure 4, Flora 11a; Fyles et al., 1994) and the Mary Sachs gravel at Duck Hawk Bluffs on the southwest side (Flora 10); the other group is represented by deposits of the 


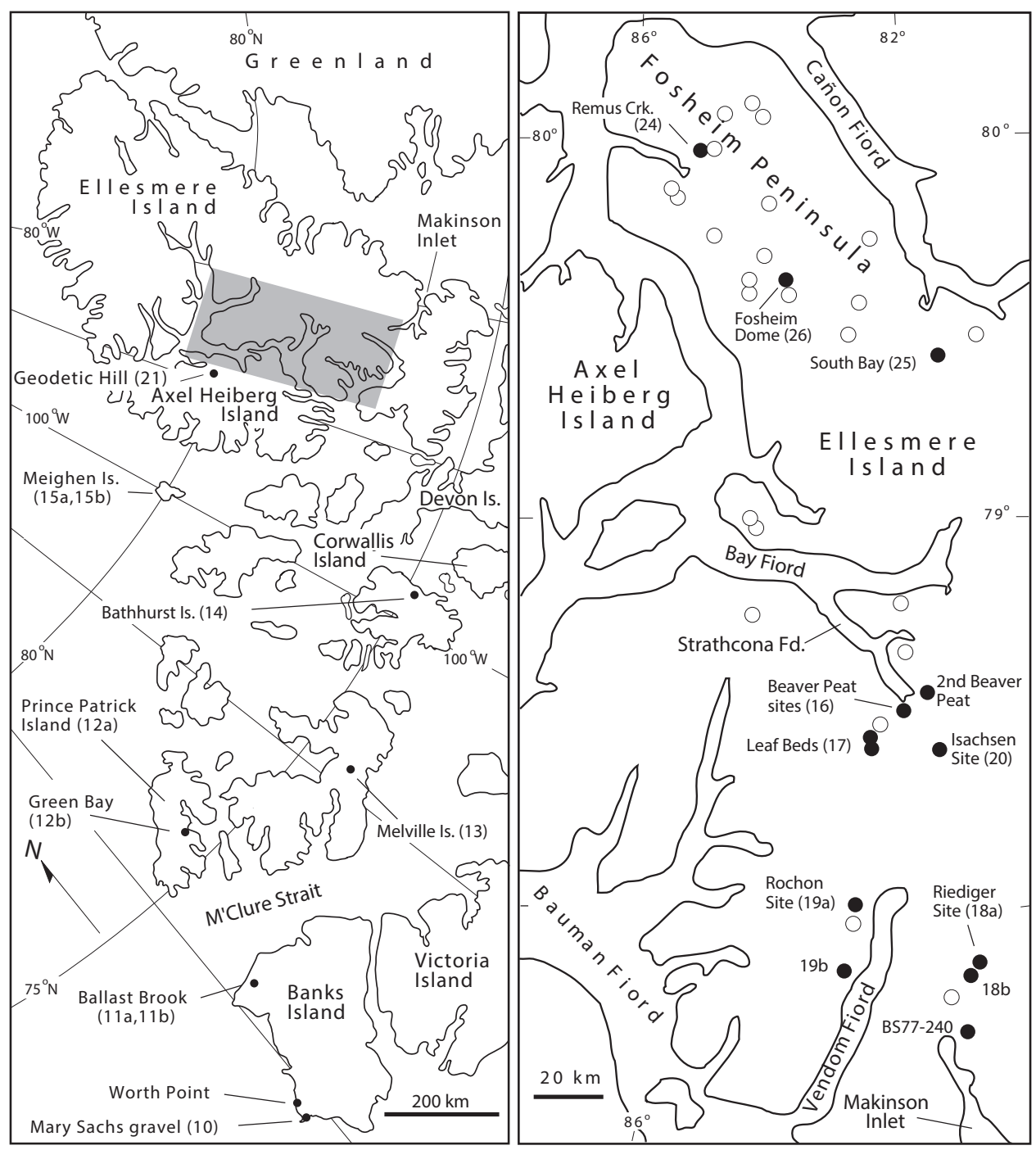

FIGURE 4. Detailed site location maps of sites from the western islands of the Canadian Arctic Archipelago, Canada. Shaded area on map at left indicates the region covered in the map at the right (note rotation). Numbers beside sites refer to site codes used in Appendices and throughout this paper. Un-numbered circles represent Neogene to Early Quaternary sites from which plant and/or arthropod fossils have been isolated.

widely distributed Pliocene Beaufort Formation (Flora 11a; Fyles, 1990). An angular unconformity separates the Ballast Brook Formation and the Beaufort Formation. Each unit is discussed separately below.

Beaufort Formation. Preserved organics from the Beaufort Formation on Banks Island have only been studied at Ballast Brook (Matthews, 1987; Fyles et al., 1994), although the formation may outcrop at other localities on the western part of the island (Vincent, 1990). Overlying the unconformity at Ballast Brook, the sand and gravel of the Beaufort Formation is approximately $30 \mathrm{~m}$ deep (Figure 4).
Except for at least two sites, the organic beds in the Beaufort Formation at Ballast Brook are mostly allochthonous. The exceptions are a moss peat discussed by Kuc and Hills (1971) and a single exposure of partially cemented forest-floor debris, located near the top of the Beaufort sequence at the type locality for the Ballast Brook Formation (Fyles et al., 1994). The latter deposit contains well-preserved cones and shoots of a larch similar to Larix groenlandii (Bennike, 1990) plus mats of leaf fascicles of Pinus subsection Strobus with medial resin canals (previously referred to as five-needle pine of subsection Cembrae sensu Engelmann, 1880). 
TABLE 1. Comparison of selected pollen spectra from Canadian Neogene Arctic.

\begin{tabular}{|c|c|c|c|c|c|c|c|c|c|c|c|c|c|}
\hline \multirow[t]{2}{*}{. } & \multirow{2}{*}{$\begin{array}{c}\begin{array}{c}\text { Mary } \\
\text { Sachs } \\
\text { grav }\end{array} \\
\text { FG13a }\end{array}$} & \multirow{2}{*}{$\begin{array}{c}\text { BB } \\
\text { Fm. } \\
\text { Unit } 5 \\
139\end{array}$} & \multicolumn{3}{|c|}{$\begin{array}{c}\text { Beaufort Fm. Ballast } \\
\text { Brook }\end{array}$} & \multicolumn{2}{|c|}{$\begin{array}{l}\text { Prince Patrick } \\
\text { Island }\end{array}$} & \multicolumn{2}{|c|}{$\begin{array}{l}\text { Beaufort Fm, } \\
\text { Meighen Is. }\end{array}$} & \multirow{2}{*}{$\begin{array}{c}\text { Beav. } \\
\text { Pond } \\
19 a\end{array}$} & \multicolumn{2}{|c|}{ Riediger site } & \multirow{2}{*}{$\begin{array}{c}\begin{array}{c}\text { Isach- } \\
\text { sen }\end{array} \\
37 \mathrm{c}\end{array}$} \\
\hline & & & $\begin{array}{l}171 \\
2 m\end{array}$ & $\begin{array}{l}252 \\
28 m\end{array}$ & $04 a$ & $\begin{array}{l}\text { Bft.Fm } \\
88-1 e\end{array}$ & $\begin{array}{c}\text { Green } \\
\text { Bay }\end{array}$ & LM9 & $65 b$ & & $27 e$ & $31 \mathrm{c}$ & \\
\hline$\sum$ Pinaceae & 19.1 & 43.8 & 40.2 & 54.8 & 9.1 & 36.9 & 39.9 & 20.0 & 40.7 & 23.8 & 19.1 & 20.9 & \\
\hline Picea & 1.9 & 24.0 & 12.0 & 22.2 & 3. 1 & 6.8 & 8. 6 & 8. 6 & 6.4 & 17.7 & 15.1 & 20.9 & 19.6 \\
\hline Pinus & 17.2 & 9.2 & 17.7 & 18.0 & 6.0 & 30.1 & 31.2 & 12.4 & 34.3 & 6.1 & 4. 0 & & 1. 8 \\
\hline Abies & + & 1.5 & 1.2 & 1.2 & + & & & & + & & & & \\
\hline Tsuga typ. & 2.8 & 2. 9 & 4. 6 & 3.3 & & & & & & & & & \\
\hline Larix typ. & + & + & & & & & + & & & & & + & \\
\hline TCT & + & 16.4 & 7.7 & 9.1 & + & & & 9.7 & + & & & + & \\
\hline Betula & 46.2 & 6. 1 & 12.2 & 13.4 & 14.5 & 29.4 & 11.4 & 15.6 & 28.6 & 48.4 & 50.5 & 38.0 & 49.9 \\
\hline Alnus & 21.3 & 9.8 & 21.8 & 11.6 & 62.9 & 15.0 & 12.0 & 5.9 & 13.7 & 5. 2 & 21.5 & 23.8 & 19.4 \\
\hline Corylus & & 1.6 & 2.2 & 1.9 & & 3.2 & & 1.6 & + & 9.4 & 1.1 & & + \\
\hline Salix & + & + & 1.9 & + & 4.7 & & 2.5 & & 1.8 & & & + & + \\
\hline Misc & 1.1 & 9.6 & 4. 9 & + & & & & & 1. 2 & & & + & \\
\hline hardwoods & $\begin{array}{c}\mathrm{Pt}, \mathrm{UZ} \text {, } \\
\mathrm{C}\end{array}$ & $\begin{array}{l}\text { Q, Jg, } \\
\mathrm{C}, \mathrm{CO}, \\
\mathrm{UZ}, \mathrm{Ix}\end{array}$ & $\begin{array}{l}\mathrm{Q}, \mathrm{Jg} \\
\mathrm{C}, \mathrm{UZ} \\
\mathrm{IX}\end{array}$ & $\mathrm{Jg}, \mathrm{C}$ & & & & & $\mathrm{P}, \mathrm{CO}$ & & & $F$ & \\
\hline Myrica & & + & + & + & + & + & + & & 3. 6 & & 1. 0 & 2.5 & 1. 4 \\
\hline Ericales typ. & 3.8 & 2. 6 & 1. 9 & 1.7 & + & + & + & + & 1. 2 & 6.8 & 2. 5 & 8. 9 & 1.4 \\
\hline Poaceae & & + & & + & + & 7.9 & 16.0 & 1. 1 & + & + & + & + & + \\
\hline Cyperaceae & & + & + & + & 4. 8 & 4. 2 & 13.0 & & 9.4 & 1.9 & 3. 2 & 4. 1 & 3. 5 \\
\hline Dryas* $^{*}$ & & & & + & & & & 3.2 & & & & & \\
\hline Asteraceae & & 1. 4 & + & + & & + & & + & + & + & + & & + \\
\hline$(\text { Misc. herbs })^{\wedge}$ & & (16) & & & & & & & & & & & \\
\hline Pollen Sum & 319 & 1140 & 1347 & 836 & 318 & & & 186 & 329 & 310 & 629 & 315 & 427 \\
\hline Sphagnum & + & 3.5 & 2.1 & 12.2 & 1. 8 & 7.7 & 5.8 & 5.3 & 20.6 & 151.0 & 3. 3 & + & + \\
\hline
\end{tabular}

Mary Sachs gravel sample studied by T. Ager (U.S.G.S.) (pers. comm., 1993); all others studied under contract by M. Frappier (Univ. of Ottawa; pers. comm. 1993).

Percentages do not total to 100 because not all types are listed Hardwood abbreviations: $\mathrm{Q}=$ Quercus, Ix=Ilex, Pt=Pterocarya,

$\mathrm{C}=$ Carya, UZ=Ulmus/Zelkova, $\mathrm{CO}=$ Carpinus/Ostrya, Jg=Juglans $\mathrm{T}=$ Tilia, $\mathrm{F}=$ Fraxinus, $\mathrm{P}=$ Populus

In spite of the presence of numerous pine macrofossils, a pollen sample from the bed (04a, Table 1) shows only $6 \%$ pine pollen. This may be due to the dominance of alder pollen (60\%). Two other pollen samples listed in Table 1 come from lower in the Beaufort Formation at Ballast Brook. They are difficult to compare with the forest debris spectrum because they come from silt and are more likely to contain rebedded pollen. The curious fact about these samples is that they contain so little pine pollen even though macrofossils show with certainty that pine was growing in the region. The lowest of the three Ballast Brook Beaufort Formation pollen samples comes from a position only $2 \mathrm{~m}$ above the contact with the Ballast Brook Forma- tion, and not surprisingly, contains nearly $5 \%$ hardwood pollen, all of it probably rebedded from the Ballast Brook Formation.

Uncompressed wood of up to $40 \mathrm{~cm}$ in diameter has been observed in the upper portion of the Beaufort Formation at Ballast Brook (Unit B of Fyles et al., 1994). Of the 32 samples Mendell (2006) studied from that location, 24 were spruce or larch, the rest comprising Pinus. The tree rings suggest growth rates were sometimes as slow as modern treeline (Kay, 1978), although, the averages for Picea-Larix reported in Mendell (2006) were well within the forest limit.

Climate estimates derived from the flora and fauna of the Beaufort Formation at Ballast Brook 
also do not explain evidence of slow growth. The mutual climatic range comparison (MCR) using fossil beetles (Elias and Matthews, 2002) yielded Tmax-mean and Tmin-mean for climate at the time of deposition of one of the Ballast Brook Beaufort Formation samples (3-73). They conclude that Tmax-mean was $12.8^{\circ} \mathrm{C}, 11.1^{\circ} \mathrm{C}$ warmer than at present, and Tmin-mean, $-21^{\circ} \mathrm{C}$, was $20^{\circ} \mathrm{C}$ warmer than at present. Fletcher et al. (2019a), also based on beetles but using a different database and statistical approach, suggest that Banks Island may have been a further $10^{\circ} \mathrm{C}$ warmer for minimum temperature compared to Elias and Matthews' (2002) estimations (i.e., approximately $-11^{\circ} \mathrm{C}$, or $30^{\circ} \mathrm{C}$ warmer than present). Fletcher et al. (2019a) proposed that previous estimates based on beetles were biased to cold temperature estimates for minimum temperatures. The more recent estimates are more in keeping with the climate estimates for the Beaufort Formation at Banks Island derived from a mutual climate range method for the vegetation (Fletcher et al., 2017). They reported a Mean Annual Temperature (MAT) of $6^{\circ} \mathrm{C}$, Maximum Temperature of the Warmest Month (Tmax) of $21^{\circ} \mathrm{C}$, Minimum Temperature of the Coldest Month (Tmin) of $-9^{\circ} \mathrm{C}$, Mean Annual Precipitation (MAP) of 550 $\mathrm{mm}$, precipitation of the wettest quarter (3wet) of $250 \mathrm{~mm}$, and precipitation of the driest quarter (3 dry) of $80 \mathrm{~mm}$.

Ballast Brook Formation. Originally considered an informal unit of the Beaufort Formation by Hills (1969) and Kuc and Hills (1971), Fyles et al. (1994) distinguished the two as separate. Although the base was not exposed, Fyles et al. (1994) estimated the formation as $40 \mathrm{~m}$ thick, comprising five Units; $1-3$ and 5 are sandy to silty-clay, and 4 is a 2 $\mathrm{m}$ thick peat bed, in which tree stumps in growth position have been found in at least one location (see Williams et al., 2008). The contact with overlying Beaufort Formation is a low-angle unconformity, the formation of which might have coincided with the regional episode of erosion (Messinian) documented by McNeil and others (2001). If this is correct then the age of the Ballast Brook Formation is no younger than mid-Miocene, a conclusion also suggested by its fossils (Fyles et al., 1994).

An example of the kind of modern depositional environment similar to that of the thick peat in the upper part of the Ballast Brook Formation is the Taxodium swamps of the southeastern USA. Many of the seeds and other macroflora (Decodon, Saururus, Taxodium, Liriodendron, Pinus [Pinus], Ludwigia, Hypericum, Morus) accumulating in such swamps also occur as fossils in either or both the
Ballast Brook Formation and Mary Sachs gravel. The chief difference is that the Banks Island deposits also contain fossils of at least four types of conifers, nearly all of which are not found in most Taxodium swamps either because they have become extinct in North America (Metasequoia and Glyptostrobus) or such sites are presently too warm (Picea and Larix). As well as northern conifers, the Ballast Brook Formation also contains a few fossils of typical Arctic/Subarctic shrubs such as Andromeda. Pollen spectra from the Ballast Brook Formation (Table 1; Fyles et al., 1994) contain higher percentages of pine and spruce than mid-Miocene sites farther south in Alaska (White and Ager, 1994).

Study of an in situ forest bed from the Ballast Brook peat, at an exposure near the formation type locality, shows that the dominant tree was one or more species of Pinus subsection Strobus and that the regional lowland forests also contained Glyptostrobus (water pine) and Picea (spruce). This is a more depauperate tree flora than documented by Fyles et al. (1994) who marked the presence (in addition to the above) of Metasequoia, Taxodium, Thuja, Larix, Abies, Tsuga, Pseudotsuga, Pinus (Pinus), and the broadleaf tree Liriodendron. However, the fossil trees reported by Williams et al. (2008) came from one peat-swamp exposure while fossils in Fyles et al. (1994) came from several different peats at the type section as well as from alluvial sands and silts, which undoubtedly contain rebedded tree fossils from nearby upland communities. Based on their analysis of the peat, Williams et al. $(2008$, p. 160) concluded that the lowland forests of the area "were of moderate biomass and productivity typical of modern cool temperate forests in North America." Another study of the Ballast Brook Formation wood (Mendell, 2006) confirmed the high percentage of pine (45 of 56 samples), and also reported Picea, Metasequoia, and Glyptostrobus wood. They suggested the climate was too cool to support optimal growth of the mesothermal genera Metasequoia/Glyptostrobus, which had narrow rings $(0.2 \mathrm{~mm})$. These species are not present in the Pliocene Beaufort Formation at the same site, as is expected with the slow deterioration in Arctic climate conditions from Miocene to Pleistocene.

A study of the taphonomy of the needles found at Banks Island, in both the Ballast Brook and Beaufort Formations and compared to other sites (Witkowski et al., 2012), found that the preservation of the Largerstätten was not an important predictor of age of the site, but that quality of the 


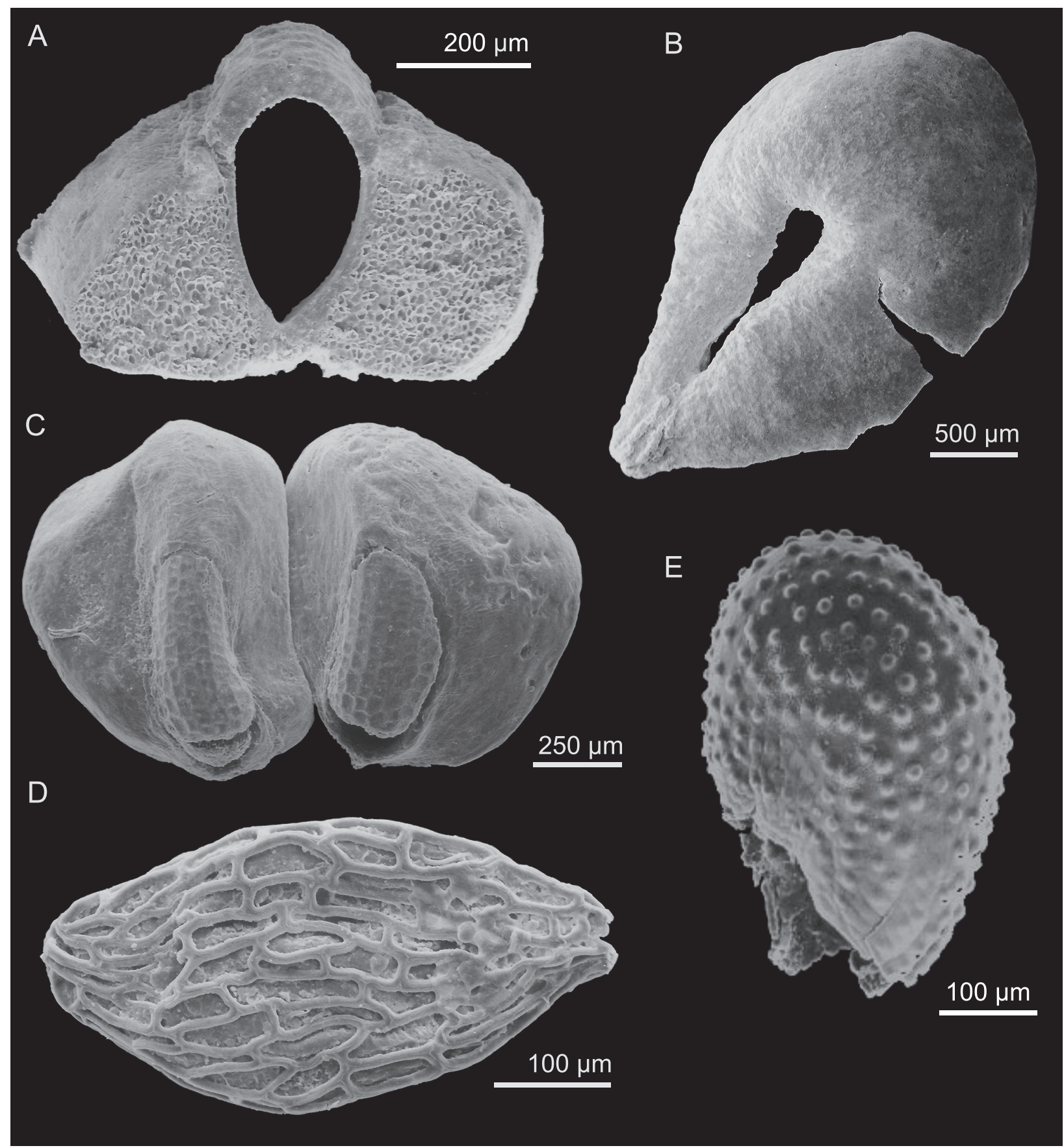

FIGURE 5. SEM micrographs of selected plant macrofossils from Mary Sachs gravel at Duck Hawk Bluffs, southern Banks Island. (A) Microdiptera/Mneme type (Lythraceae), seed, cross-section with germination valve to top, sample MRA 7-18-91-3, GSC 141399; note the absence of obvious dorsal furrows as seen on specimen from the Ballast Brook Formation (Fyles et al., 1994). Germination valve contains approximately ten rows of pits; (B) Parthenocissus? (Vitaceae), half of seed, ventral face showing one ventral infold, sample MRA 7-1-88-2, GSC 141400; (C) Microdiptera/Mneme type (Lythraceae), two joined seeds, ventral view with apex up, sample MRA 7-18-91-3, GSC 141401; note that the specimen on the right contains a fold on the wing, undoubtedly due to packing of the seeds in the capsule. This indicates how one of the characters used to distinguish Microdiptera from Mneme, relative development of the 'wings' is likely due to considerable variation even in seeds from the same plant and supports Tiffney's (1981) conclusion about the dubious validity of the many named species; (D) Orchidaceae?, seed, sample FG 91-13a, GSC 141402; (E) Nigrella sp. (Melastomaceae), seed, from the site 3 type section of the Ballast Brook Formation (see Fyles et al. 1994), GSC 141421. 


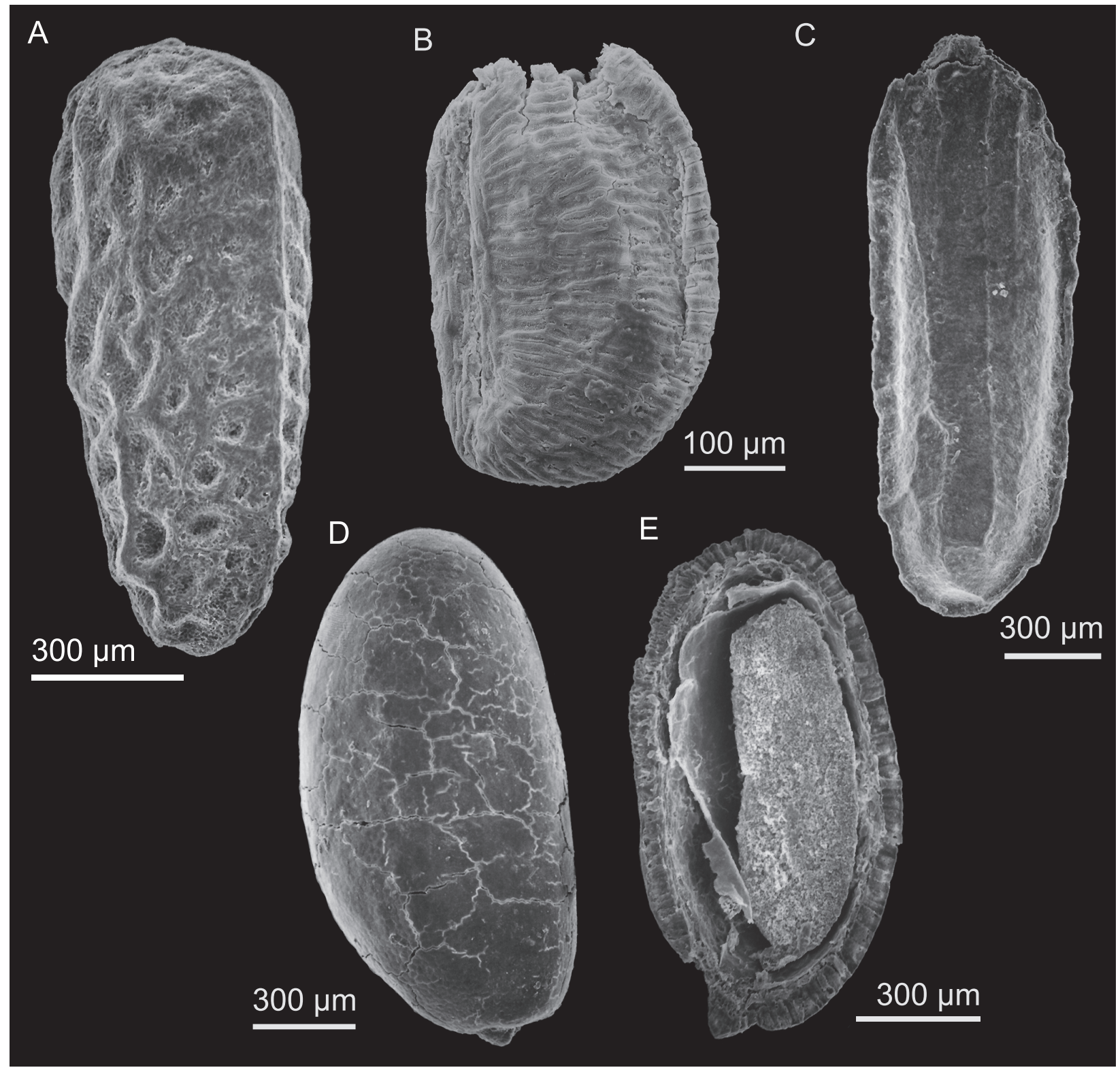

FIGURE 6. SEM micrographs of selected plant macrofossils from the Neogene on the Canadian Arctic Archipelago. (A) Rubus sp. (Rosaceae), seed, Mary Sachs gravel, sample MRA 7-7-88-1, GSC 141422; (B) Ludwigia sp. (Onagraceae), seed, Mary Sachs gravel, sample FG 91-13a, GSC 141403; (C) Verbena sp. (Verbenaceae), seed, Prince Patrick Island, NWT, Beaufort Formation, GSC 141404; (D) Unknown seed; Beaver Pond, Ellesmere Island, Nunavut, sample FG 88-8b, GSC 141405; (E) Cross-section of seed of the same type as shown in D, Beaver Pond, sample FG $88-8 b$, GSC 141406.

molecular preservation of the leaves and of their micromorphology were linked - polysaccharides play an important biomechanical function. The Ballast Brook material was, in fact, less degraded than that of the overlying Beaufort Formation flora.

\section{Southern Banks Island - Duckhawk Bluffs (Northwest Territories)}

Mary Sachs gravel. Duck Hawk Bluffs is a nearly continuous sequence of coastal bluffs near the vil- lage of Sachs Harbour on southern Banks Island, which cover several kilometres. Along the Bluffs a Quaternary sequence (Vincent, 1990) rests on woody gravel and sand that was originally considered to be part of the Beaufort Formation. Plant macrofossils collected and reported first by Hills et al. (1974), and later by Matthews (1987), showed conclusively that the Beaufort-like deposits at Duck Hawk Bluffs contained a different, and to all appearances, more archaic flora than Beaufort 


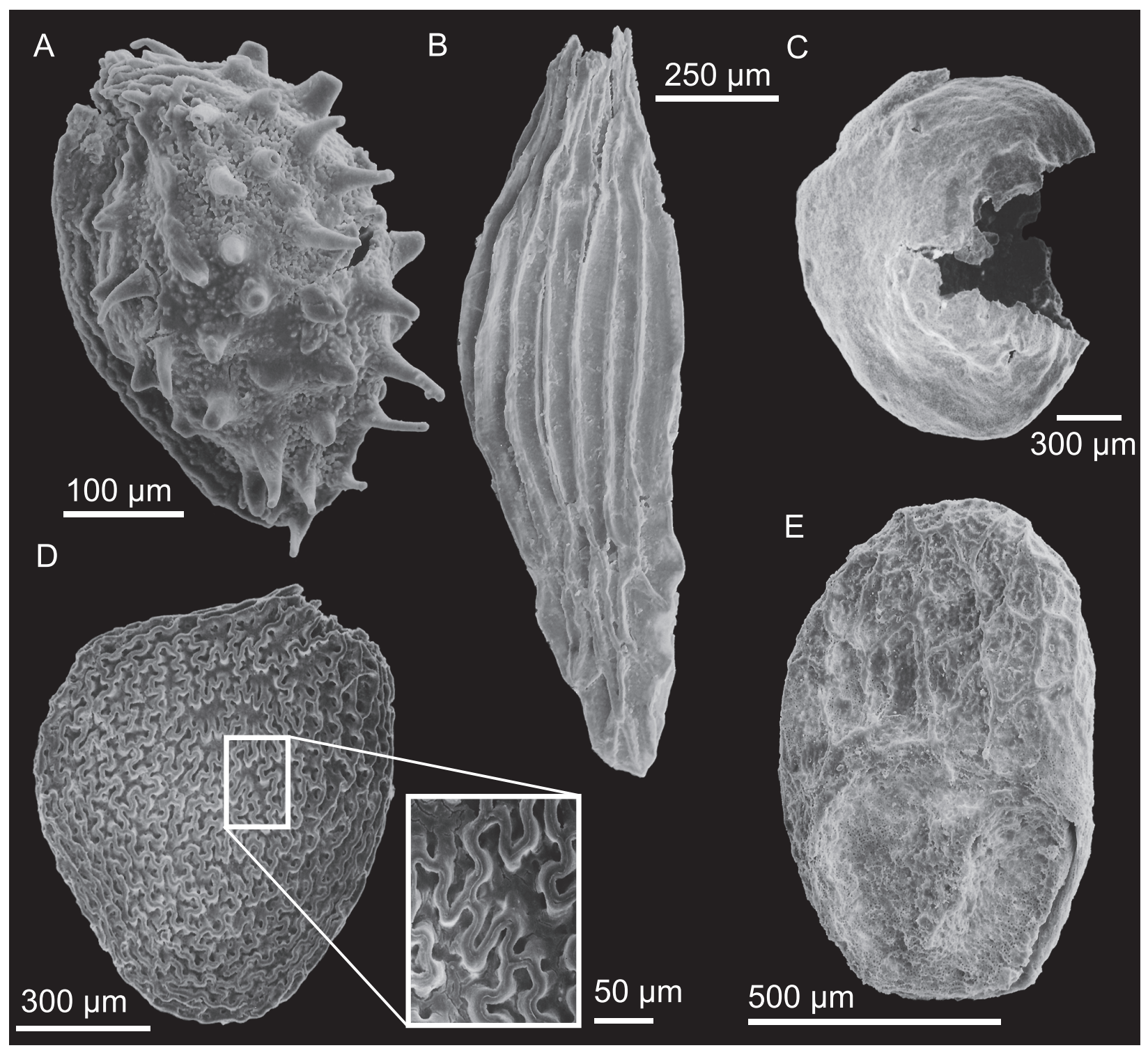

FIGURE 7. SEM micrographs of selected plant macrofossils from Mary Sachs gravel at Duck Hawk Bluffs, southern Banks Island, NWT. (A) Saxifraga sp. (Saxifragaceae), seed, sample FG 91-13a, GSC 141407; (B) Hydrangea?, sample FG 91-13a, GSC 141408; (C) Morus sp. (Moraceae), seed, sample MRA 7-23-85-2, GSC 141409; (D) Physalis sp. (Solanaceae), seed, sample MRA 7-7-88-3, GSC 141412; note in magnified view of the seed the pits in the lumina which distinguish Physalis from Solanum (Mai and Walther, 1988); (E) Teucrium sp. (Lamiaceae), seed, sample MRA 7-18-91-3, GSC 141413.

sediments in the type region on Prince Patrick Island. In light of such findings, Fyles (1990) separated the Duck Hawk Bluffs deposits from the Beaufort Formation, proposing the informal name 'Mary Sachs gravel'.

Matthews et al. (1987) defined two different distinct units ( $\mathrm{Tb} 1$ and $\mathrm{Tb} 2$ ) within the sequence now called Mary Sachs gravels. However a subsequent study (Matthews, 1989) showed that the differences in the floras of these two units are due more to differences in lithology than age. Both are now known to contain fossils indicative of a mid-
Miocene age and should be considered facies within the Mary Sachs gravel. Collections by Matthews in 1991 showed that similar fossils exist immediately beneath the early Quaternary sediments that cap the section, with no evidence of Beaufort Formation at Duck Hawk Bluffs. Evans et al. (2014) suggested that the sequence actually represents organics and sediments eroded by glaciers or their meltwater from their Neogene position somewhere south-east of Banks Island, and deposited at Mary Sachs first by high dischargehigh frequency events, then lower energy-high fre- 
quency events as the ice margin became increasingly distal. Differences between the flora should be interpreted with this post-depositional history in mind.

Despite this likely reworking, the Ballast Brook Formation and Mary Sachs gravels floras are similar with only some minor differences. Seeds of the Microdiptera/Mneme type occur in the Mary Sachs gravel (Figure $5 \mathrm{~A}$ and $5 \mathrm{C}$ ), but not in the Ballast Brook Formation. The Mary Sachs seeds are clearly related to one or both Microdiptera or Mneme as redefined by Tiffney (1981), but appear to be almost intermediate between the two. The seed body is more or less buried in the wings (Figure 5A) as with Mneme, but the germination valve contains 10 rows of pits as in Microdiptera, and there is no indication of the presence of the deep dorsal grooves found in Mneme. In contrast, one of the specimens from the Ballast Brook Formation (Fyles et al., 1994) displays well-developed dorsal grooves and in all respects is identical to descriptions and illustrations of Microdiptera parva Chandler (Tiffney, 1981; Friis, 1985).

Seeds representing at least two species of the aquatic herb Ludwigia (seedbox) are relatively abundant and well preserved in Mary Sachs gravel (Figure 6B), but are very rare in the Ballast Brook Formation. A few fragments of seeds with the characteristics of Vitaceae also occur in the Mary Sachs beds; none from the Ballast Brook Formation. One of these is illustrated in Figure 5B. It shows half of the ventral face of the seed with one of the infolded regions. In cross section, the seed wall reveals one-layered elongate sclerids, and in the apical region (ventral side showing in Figure 5B) shows multilayered isodiametric sclerids, both characters typical of Vitaceae seeds (Tiffney and Barghoorn, 1976). The seeds are most similar to those of the genus Parthenocissus, though more complete specimens would be required to confirm this determination. Today, Parthenocissus (Virginia creeper) is the most northern genus of Vitaceae, occurring even in the rigorous environment of the north shore of Lake Superior and Lake Manitoba region. It is a member of the mixed hardwood forest community-the type of forest suggested by other plants from Mary Sachs gravel. Figures 5D, $6 \mathrm{D}$, and $7 \mathrm{~B}$ illustrate some of the unidentified or tentatively identified seeds from the Mary Sachs gravel at Duck Hawk Bluffs.

Among the most spectacular plant macrofossils to come from the Mary Sachs gravel are the excellently preserved fossils of the extinct butternut Juglans eocinerea, described in detail by Hills et al.
(1974). Not only are the J. eocinerea nuts the northernmost fossils of butternut ever recorded (contrary to figure 52 of Manchester, 1987), but they also represent the only fossil occurrence of scabrate-shelled butternuts in North America (Manchester, 1987). Hills et al. (1974) compared the $J$. eocinerea nuts to those of the extant North American species $J$. cinerea L., but in a review of fossil Juglans, Manchester (1987) suggested instead a relationship to the extant oriental species, $J$. mandshurica Maxim. If so, then the J. eocinerea duplicates the distributional pattern of some of the other plant fossils discussed here: extinct forms were once resident in Arctic North America but now have their closest, and often only living relatives, in east Asia.

In spite of the floristic distinctions between Mary Sachs gravel and the Ballast Brook Formation, they share many exotic taxa the presence of which immediately sets them apart from typical Beaufort Formation floras. Among these taxa are Aldrovanda (Droseraceae), Glyptostrobus (Cupressaceae), Nigrella (Melastomaceae, Figure 5E), Damasonium (Alismataceae), Morus (Moraceae, Figure 7C), and Teucrium (Lamiaceae, Figure 7E).

Wheeler and Arnette (1994) reported Tsuga wood from the Mary Sachs gravels, adding to the already recognised pollen and non-wood macrofossils at the site; they interpreted the presence of Tsuga as indicative of plentiful moisture.

Although this review is concerned primarily with macrofossils, pollen evidence, when available, cannot be ignored. Table 1 shows pollen spectra from Mary Sachs gravel, the Ballast Brook Formation, and several other sites from the Arctic. More detailed information on pollen from the Ballast Brook Formation is in Fyles et al. (1994).

The pollen spectra from Mary Sachs gravel and Ballast Brook Formation are markedly different. TCT types (Taxodiaceae-Cupressaceae-Taxaceae) are abundant at Ballast Brook; rare in the Mary Sachs gravel sample. The Mary Sachs spectrum also contains high percentages of Betula and Alnus, and were it not for the Tsuga and miscellaneous hardwoods, might easily be mistaken for a Quaternary age sample from the southern part of the present-day Northwest Territories (although the birch macrofossils are quite different than those seen in any Quaternary sample). Some of the other distinctions between the spectra (e.g., the contrast in diversity of miscellaneous herbs) are probably due to differences of the pollen sums and counting 
practice, but the differing taphonomic history of the sites could also be the cause.

\section{Prince Patrick Island (Northwest Territories)}

Beaufort Formation. The Beaufort Formation (Pliocene) was first described on Prince Patrick Island in the late 1950s (Tozer, 1956). Florules from most sites (except Green Bay beds - see below) are similar and in Appendix 1 are shown as a single flora (12a). See Matthews et al. (1990b) for details on the content of individual florules and faunules and suggestions as to their palaeoclimatic and biostratigraphic significance.

Macrofossils of two Pinus (Strobus) Section Quinquefoliae species, one Pinus (Pinus) Subsection Contortae species, larch (Larix), fir (Abies), cedar (Thuja), and possibly hemlock (Tsuga) occur in the Beaufort Formation on Prince Patrick Island (Matthews et al., 1990b). This shows that the forests growing on the island during deposition of the Beaufort Formation were much more diverse than those growing in the present boreal forest. To some degree the single pollen sample from the island (Table 1; 88-1e) confirms this conclusion because unlike modern pollen samples from northern forests it contains higher percentages of pine than spruce and enough Corylus pollen to indicate that this non-boreal shrub was growing on the island.

Green Bay beds. The known exposure of the Green Bay beds is limited to a single location on the east of Prince Patrick Island (Figure 4; Flora 12b). They consist of approximately $2.5 \mathrm{~m}$ of fine detrital peat and silt, which is apparently inset into sediments of the Beaufort Formation. The detrital organic deposits from which fossils discussed come, underlie a pebble zone which contains glacial erratics. Autochthonous peats above this gravel zone are evidently of Quaternary age and contain bryophyte fossils and a small assemblage of plant fossils that differ markedly from those in the underlying allochthonous organics (sample FG $10 \mathrm{a} / \mathrm{b}$ in figure 5 of Matthews et al., 1990b).

The fossil flora from the Green Bay beds is different from typical Beaufort Formation floras elsewhere on the island and on other islands. Pinus, Thuja, Aracites, Physocarpus, and Sambucus, all found in typical Beaufort assemblages, are absent. Presence of fossils of Decodon, Hypericum, and Verbena (Appendix 1), all plants found well south of the modern northern boreal zone, clearly indicate a pre-Quaternary age for the Green Bay beds. Spruce (Picea) and larch (Larix) fossil needles occur in the Green Bay beds. They may have been the only conifers growing on the island at the time of deposition, and if so, Green Bay beds forests were much less diverse than those growing during Beaufort Formation time.

The Green Bay beds were resampled in 1991. A new addition to the flora is the fossil genus Tubela (Betulaceae). Similar fossils from Meighen Island were formerly referred to the fossil species Alnus tertiaria Dorof. in Takht. (Matthews, 1987). We now know, based on excellently preserved fossils from high terrace sediments on Ellesmere Island (see below), that Tubela and $A$. tertiaria are probably the same plant. Well preserved leaves of Dryas also occur in the Green Bay beds. They are clearly not from the modern tundra species ( $D$. integrifolia Vahl.) resembling instead leaves of $D$. octopetala L. Nevertheless, they do suggest an open, tundra-like environment, a conclusion supported by occurrence of remains of other tundra/ alpine plants (Saxifraga oppositifolia L. and Oxyria digyna Hill). In fact, these three plant taxa form a cohort that occurs at several other late Pliocene sites in the High Arctic (Fyles et al., 1998); including Meighen Island (15b) and Kap København, Greenland (Bennike, 1990).

\section{Melville, Bathurst, and Cornwallis Islands (Northwest Territories and Nunavut)}

Beaufort Formation. The most extensive exposures of the Beaufort Formation occur on the westernmost islands of the Canadian Arctic Archipelago, but there are isolated occurrences of sediments of suspected Beaufort age on islands farther east. A.L. Washburn discovered a small exposure on Cornwallis Island (Nunavut) that contained wood fragments later identified as Pinus strobus L. (Obst et al., 1991) or simply as Pinus (GSC fossil wood report 82-56). A pollen analysis of the same sample (GSC palynological report 833 ) revealed dominance of pine vs spruce pollen (25.1\% Pinus).

More definitive collections of palaeofloras have been found at sites on Melville Island (Northwest Territories and Nunavut) and Bathurst Island (Nunavut). The Melville Island specimens originate in sands containing poorly preserved wood and rare organic debris (Hodgson et al., 1984). Despite the paucity of fossils compared to typical Beaufort sediments farther west, presence of Aracites, Myrica arctogale, Physocarpus, Verbena, and Sambucus (Flora 13), clearly suggest an age similar to deposits on Prince Patrick and Banks Islands. Most wood specimens from Melville Island have been identified as Picea, but one of the wood fragments from the site has been identified as 
Pseudotsuga (by H. Jetté, Geological Survey of Canada), indicating that Melville Island may also possess deposits as old as the Miocene Ballast Brook Formation (Fyles et al., 1994).

Presence of Beaufort type deposits on Bathurst Island is suggested by a small, coherent allochthonous block of peat found in association with woody debris in a creek bed (Fyles, personal commun., 1992). Though the peat clast is not in place, its content of spruce and larch calls at least for a minimum age of late Pliocene. Sediments containing a similar palaeoflora to the Beaufort Formation occur as high-level terrace deposits on Ellesmere Island. Some have applied the name Beaufort to these deposits, but Fyles (1989) cited reasons for not lumping these high-level deposits with the Beaufort Formation even though some of them may be of the same age as the Beaufort Formation.

\section{Meighen Island (Nunavut)}

The most detailed studies of the flora of the Beaufort Formation are based on deposits in the Bjaere Bay region of Meighen Island (Figure 4). Although initial reports were relatively brief (Fyles et al., 1991), Barendregt and colleagues (personal commun. 2020, manuscript in review) provided comprehensive details on the fauna and flora as well as evidence showing the marine deposits, a unique feature of the Beaufort Formation on Meighen Island, to be about 3.2 Ma in age.

The Meighen Island biota are grouped according to whether the fossils come from below (15a) or above $(15 b)$ the marine unit. There are some potentially important differences between the two assemblages. Deposits below the marine unit contain fossils of plants such as Epipremnum crassum, Betula apoda Takhtajan type, Decodon globosus Nikit. type, Betula populifolia Marsh. type and Abies, none of which occur with certainty above the marine unit. These differences may signify local extinction of these taxa on Meighen Island, due either to climatic fluctuations at about the time of deposition of the marine unit or to the deposits immediately beneath the marine unit being significantly older than those above.

Several plant taxa found in the Beaufort Formation at other sites are also missing from all of the Meighen Island floras. The most important of these are Paliurus, Hypericum, Verbena, and Sambucus. The high latitude of Meighen Island cannot be the only explanation for such omissions because other sites at about the same latitude on Ellesmere Island do contain some of these taxa.
The climate analysis of Meighen Island sites by Fletcher et al. (2017) showed somewhat higher mean annual precipitation for the communities above and particularly below the marine unit, compared to the Beaver Pond (Flora 16) and Fyles Leaf Beds (Flora 17) floras on Ellesmere Island, but not large or consistent differences in temperature or seasonality of precipitation. Current dating suggests that Meighen Island sites are late Pliocene, and the Ellesmere Island high terrace sediments are from the early Pliocene, $\sim 4 \mathrm{Ma}$ (Rybczynski et al., 2013; Fletcher et al., 2017; Fletcher et al., 2019b).

Many of the wood specimens found in the Beaufort Formation on Meighen Island show evidence of slow growth, comparable to trees at the current timber limit (Wheeler and Arnette, 1994). In addition, a number of the plant remains and some of the insect remains from localities above the marine unit (15b) suggest that Bjaere Bay was near regional tree line. It would have been a tree line quite unlike today's because instead of the two to three conifers currently forming tree limit (at sites south of the Canadian Arctic Archipelago), the Pliocene tree line on Meighen Island was formed by at least seven and possibly eight types of conifers. This group includes Asian pines within the subsection Strobus (with medial resin canals previously classified as Cembrae), and possibly even the Eurasian shrub pine, Pinus pumila (Pallas) Regel.

Several of the insect assemblages from Meighen Island have been studied using the MCR method (Elias and Matthews, 2002). The results are comparable to those for the Beaufort Formation from Ballast Brook, i.e., maximum yearly temperature of about $13^{\circ} \mathrm{C}$ (more than $10^{\circ} \mathrm{C}$ warmer than at present) and a warm winter minimum of about $-25^{\circ} \mathrm{C}$. Once again, Fletcher et al. (2019a), found winter temperatures to be around $10^{\circ} \mathrm{C}$ warmer than suggested by Elias and Matthews (2002), and warmest month temperatures also underestimated. These warmer estimates are closer, although still less warm, than those estimates derived from the flora at the same sites, with the floral assemblage below the marine unit suggesting a MAT of $4.3^{\circ} \mathrm{C}$; Tmax, $20.2^{\circ} \mathrm{C}$; Tmin, $-13^{\circ} \mathrm{C}$; and the floral assemblage above the marine unit, an MAT of $3.6^{\circ} \mathrm{C}$; Tmax, $20^{\circ} \mathrm{C}$; Tmin, $-11.5^{\circ} \mathrm{C}$ (Fletcher et al., 2017).

\section{Ellesmere Island, High Terrace Sediments (Nunavut)}

The Beaufort Formation was the focus of early research on Pliocene plant and arthropod fossils in 
the Canadian Arctic, and still has much to yield from the ongoing study of both new and old localities. However, non-Beaufort Formation Pliocene localities with extraordinary preservation and diversity of fossils have been 'rediscovered' from earlier explorations on Ellesmere Island and Axel Heiberg Island (Fyles, 1989; Mitchell et al., 2016; Fletcher et al., 2017); two of which have yielded vertebrate fossils (Tedford and Harington, 2003; Rybczynski et al., 2013; Wang et al., 2017). This high terrace alluvium, often with peat, organic zones, and wood, was deposited on the eastern islands of the Canadian Arctic Archipelago prior to the Pleistocene incision that formed the large inlets and fiords that characterize the islands of that region, especially Ellesmere Island (Gosse et al., 2017).

Some of the palaeoflora and fauna found in early investigations of the high terrace sediments were reported in Matthews and Ovenden (1990), and updated floral lists for the Fyles Leaf Beds and Beaver Pond sites were reported in Fletcher et al. (2017). Here we show how the floral remains of the high terrace sediments help us determine relative age of individual high terrace localities that have not been independently dated, and help discriminate between Quaternary and Neogene organic deposits on Ellesmere Island and other parts of the Arctic Archipelago. When he passed away, J.G. Fyles, discoverer of so many of the sites discussed here, was in the process of writing a treatise on the high terrace sediments. In that paper he planned formal designation of the "Taggart Formation" for some of these deposits. Though we can in no way duplicate his effort, where possible we have attempted to use his preferred names, but only in an informal sense.

Beaver Pond. High-terrace deposits near the head of Strathcona Fiord (Figure 4) include the Beaver Pond site and a collection of other peat localities that are located within one kilometre of one another. Herein, the florules both from the Beaver Pond site and these localities are considered as one flora (Flora 16). The Beaver Pond site, the most well-studied in the region, comprises a $>20 \mathrm{~m}$ steep exposure of unconsolidated fluvial sands with peat beds. The most prominent peat bed in this section is a semi-autochthonous peat which, when discovered by J.G. Fyles in 1961, stood 2.4 $\mathrm{m}$ high. Numerous beaver-cut sticks within this peat unit led to the informal name "Beaver Peat" for this unit - a name which appears in multiple publications (Fyles, 1989; Matthews and Ovenden, 1990; Matthews and Telka, 1997; Matthews and Fyles, 2000; Matthews et al., 2019). The unconsol- idated sands above this peat unit have recently been redated using terrestrial cosmogenic nuclides yielding an age for the Beaver Pond site of $3.9+1.5 /-0.5 \mathrm{Ma}$ (Fletcher et al., 2019b).

The Beaver Pond site is the only known Neogene site in the Canadian Arctic Archipelago to yield a large assemblage of vertebrate fossils. At least 12 species of mammals including mustelids, beaver, tridactyl horse, deerlet, and ursine bear, in addition to fishes and birds, are represented (Tedford and Harington, 2003; Dawson and Harington, 2007; Murray et al., 2009; Rybczynski et al., 2013; Wang et al., 2017). The site also contains an abundance of well-preserved plant and insect remains, some of them found nowhere else. This may be due in part to the peat being more autochthonous than most Neogene deposits in the High Arctic, and also because it represents a unique environment inhabited by beavers. The Beaver Pond site beaver, Dipoides sp., is an extinct semiaquatic form, about a third smaller than, and only distantly related to, the modern beaver Castor. The abundant beaver-cut wood preserved at the site shows Dipoides was clearly a wood-cutting beaver (Rybczynski, 2008), and it has been suggested that it might have built dams (Tedford and Harington, 2003), although definitive evidence of dam-building is lacking. Even if Dipoides was not a dam builder, it could have played a role maintaining a local wetland habitat through activities such as tree cutting, dragging branches into the water, feeding on aquatic plants, digging, burrowing and possibly creating underwater food caches (of branches), and lodge-building (Mitchell et al., 2016; Plint et al., 2020). One of us (JVM) has examined deposits of a Holocene fossil beaver pond and like the peat from the Beaver Pond site it contained fragments of insects rarely seen in other organic sediments.

Besides the insect and plant macrofossils mentioned here, other lines of evidence have been used to reconstruct the environment at the time of deposition. For example, Mitchell et al. (2016) used grain-size analysis, loss on ignition, and fossil diatom assemblages to reconstruct the evolution of the site from a flood plain to fen peat or lake-edge fen with intermittent beaver activity, through a more acid phase of wetlands, to a less organically productive fluvial system.

A revised taxa list for the Beaver Pond flora (Flora 16) is presented in Appendix 1. One of the samples designated 19a in Ovenden (1993) and 89-19a in Matthews and Ovenden (1990), comes from a distinctive $20 \mathrm{~cm}$ layer of black, earthy peat, dominated by an as-yet-unidentified species of 
Sphagnum (Ovenden, 1993). Sphagnum spores are also abundant in a pollen sample from the site (Table 1). Many of the pine needles from this organic zone are charred, and moreover they are associated with charred pine seeds that resemble those of the East-Asian shrub pine, Pinus pumila. In spite of the abundance of pine macrofossils in the assemblage, pine pollen accounts for only a little over $6 \%$, less than half the percentage of spruce (Table 1), but this may be due to over-representation of Betula pollen. It is significant that Corylus pollen, a type not typical of northern assemblages, accounts for $9.4 \%$.

A recent investigation of fire indicators in the main peat section of the Beaver Pond site found that macrocharcoal was present in all samples examined, but changed in concentration through the section (Fletcher et al., 2019b). The concentration of charcoal increased near the top of the section, concomitant with a change in the abundance of fire-promoting taxa, as evidenced from the pollen record. Based on the flora, climate and macrocharcoal record, the authors suggested a change over time from a high-frequency but low-severity fire regime somewhat similar to the light taiga of Siberia, to a mixed-severity fire regime more similar to that which characterizes modern North American boreal forests.

Although the taxa lists for Beaver Pond (Flora 16 ) include a few species that are now found far to the south, even south of the taiga zone, the overall composition suggests a forest-tundra, and this agrees with pollen samples which call for an open larch-dominated woodland. Judging from the macrofossil remains of larch, the species represented is probably Larix groenlandii, first described from the late Pliocene Kap København deposits in northern Greenland (Bennike, 1990).

The climate was much warmer than for Ellesmere Island today and several independent estimates of climate parameters have been made for Beaver Pond. Mutual climatic range techniques have been applied to both the floral (Flora 16) and beetle taxa lists (also grouped as 16 in Matthews et al., 2019). Working with the beetle fauna, Elias and Matthews (2002) estimated a Tmax-mean of $12.4^{\circ} \mathrm{C}$, and a Tmin-mean of $-26.6^{\circ} \mathrm{C}$. Fletcher et al. (2019a), considered these winter temperature estimates to be cold- biased, with the minimum temperature of the coldest month estimate to be warmer than the mean of the coldest month predicted by Elias and Matthews (2002), by $\sim 6^{\circ} \mathrm{C}$ using the beetle fauna and almost $20^{\circ} \mathrm{C}$ warmer using the flora.
A quantitative assessment of the climate based on the composition of the Flora 16 (Fletcher et al., 2017) reported a MAT of $1^{\circ} \mathrm{C}$; Tmax, $20^{\circ} \mathrm{C}$; Tmin, $-12^{\circ} \mathrm{C}$; MAP, $550 \mathrm{~mm}$; 3 wet, $255 \mathrm{~mm}$; and 3 dry, $100 \mathrm{~mm}$. This is within error of the previous bioclimatic method applied by Ballantyne et al. (2010), which resulted in a mean annual temperature estimate of $-0.4 \pm 4.1^{\circ} \mathrm{C}$.

Three studies have applied different approaches to determining the temperature from isotopes in the subfossil wood in the area. Ballantyne et al. (2006), first found a mean annual temperature estimate of $-5.5 \pm 1.9^{\circ} \mathrm{C}$, but later revised that estimate to $-0.5 \pm 1.9^{\circ} \mathrm{C}$ (Ballantyne et al., 2010). Csank et al. (2011a) estimated a mean annual temperature of $-1.4 \pm 4.0^{\circ} \mathrm{C}$, and June-July growth season of $15.8 \pm 5.0^{\circ} \mathrm{C}$. Finally, Csank et al. (2011b) estimated the May-September growth season from both conventional and clumped isotope analysis of freshwater mollusks, resulting in estimates of $14.2 \pm 1.3^{\circ} \mathrm{C}$ and $10.2 \pm 1.4^{\circ} \mathrm{C}$, respectively.

Two studies have applied a technique using specific bacterial membrane lipids to estimate temperature at the main Beaver Pond site. The first found a mean annual temperature of $0.6 \pm 5^{\circ} \mathrm{C}$ (Ballantyne et al., 2010). The second, using a lake calibration and refined methods, found a summer temperature of $15.4 \pm 0.8^{\circ} \mathrm{C}$ (Fletcher et al., 2019b). Collectively, these studies suggest mean annual temperatures around or just above freezing, warm summer temperatures conducive to tree growth, and relatively mild winters.

Fyles Leaf Beds. The Fyles Leaf Beds site (Figure 4, Flora 17, FG93-10a) - $10 \mathrm{~km}$ south of Beaver Pond - includes tens of meters of repeating layers of sand-silt couplets, the upper portion of each containing lenses of leaves (Rybczynski et al., 2013). Thousands of leaves like those shown in the figure have been isolated from a sample taken in 1993, which is even more extraordinary for being found in a detrital, alluvial environment. The abundance and variety of shrub and dwarf birch type leaves is remarkable.

On the strength of the unusual preservation of these leaves one might be tempted to conclude that the deposit is of Quaternary age. However, there are important clues in the flora that this is not the case. The Dryas leaves (Figure 8AA-II) are not the type $(D$. integrifolia) normally found in the Arctic today. Instead they are more like Dryas octopetala, a species no longer found in the Canadian High Arctic. Dryas octopetala leaves have been found at other late Pliocene to earliest Pleistocene sites, 


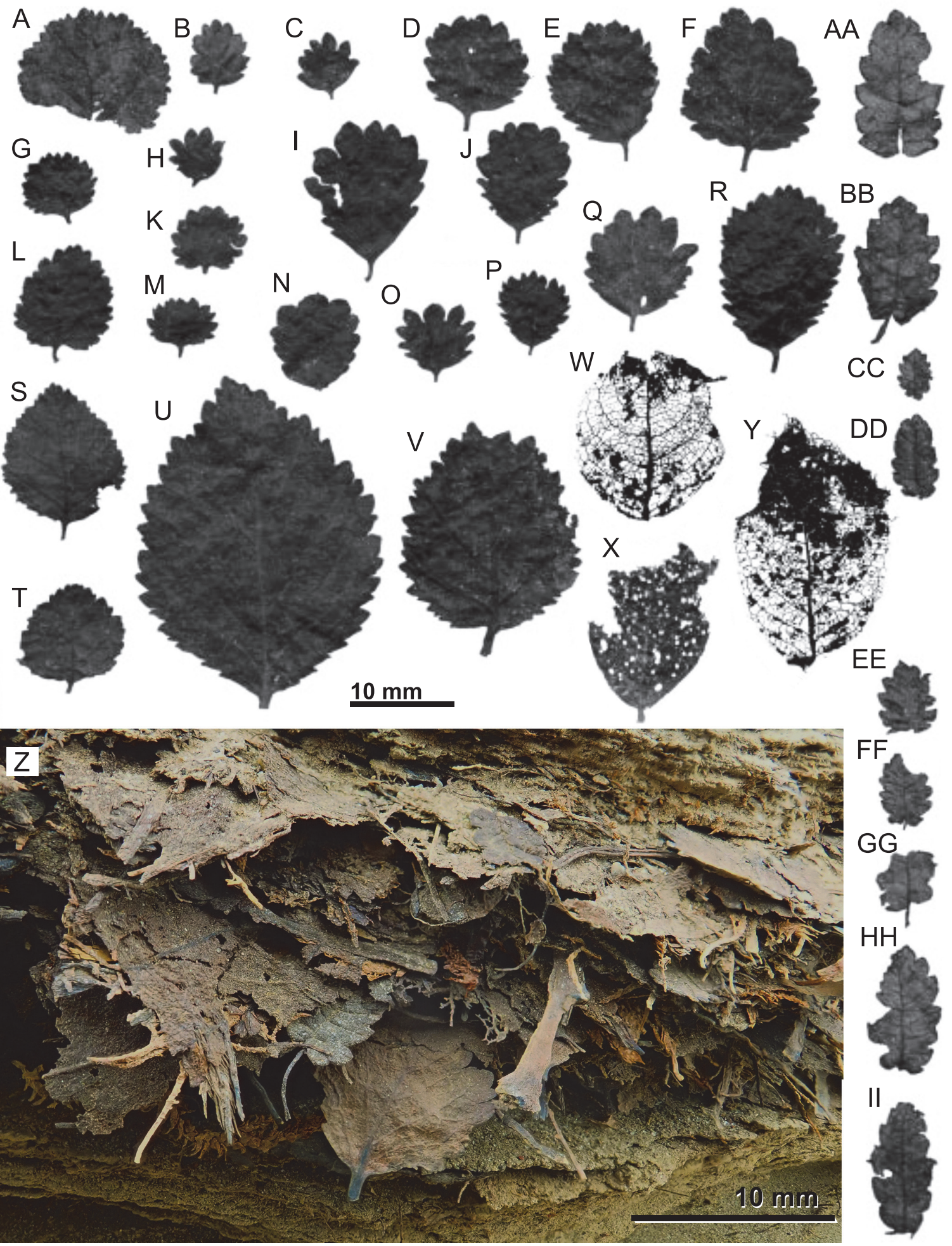

FIGURE 8. Selected leaf fossils from the Fyles Leaf Beds site (17), Ellesmere Island, Nunavut. Scale bar equals 10 $\mathrm{mm}$. (A-V) Betula spp. (Betulaceae). Note the diversity of types ranging from some similar to those from the dwarf shrub species, B. nana (e.g., D, G, O, Q), contrasted with others (e.g., S, U, V) which are more typical of high shrub and tree species of Betula; (W) Skeletonized leaf of Salix, very similar to the type seen in S. reticulata (Salicaceae). (X) Fragment of Vaccinium sp. (Ericaceae) leaf showing peculiar circular perforations; (Y) Skeletonized leaf of Salix sp. (Salicaceae); (Z) Photograph of leaves in situ in the alternating sand and organic layers of Fyles Leaf Beds. (AAII) Dryas cf. octopetala type (Rosaceae). 
e.g., Kap København in northern Greenland (Bennike, 1990) and Hvitland on northern Ellesmere Island (Fyles et al., 1998). Additionally, the larch cones from the leaf beds represent the longbracted, extinct type (L. groenlandii) found at Kap København and other Pliocene sites in the Canadian Arctic and Alaska. Finally, fossils of both Tubela and Paliurus type, which occur exclusively in the Neogene, also occur in Fyles Leaf Beds. This evidence from floral correlations has also been confirmed by a single terrestrial cosmogenic nuclide date of 3.8 Ma+1.0/-0.7 (Rybczynski et al., 2013).

Initial studies of the climate of the Fyles Leaf Beds site using a mutual range method (Fletcher et al., 2017) reported a MAT of $4^{\circ} \mathrm{C}$; Tmax, $21^{\circ} \mathrm{C}$; Tmin, $-11^{\circ} \mathrm{C}$; MAP, $800 \mathrm{~mm}$; 3 wet, $222 \mathrm{~mm}$; and 3 dry, $77 \mathrm{~mm}$. These estimates suggest a slightly warmer and wetter climate at this site compared to the Beaver Pond locality, but the differences are not significant as to infer a different period of deposition or environment.

Fyles Leaf Beds provide a unique opportunity for future research. In addition to these exquisite floral remains, the Fyles Leaf Beds site has yielded the remains of a Pliocene camel (Rybczynski et al., 2013). Considering that the site has not received the same attention as the Beaver Pond locality, its potential as an important vertebrate locality might not yet have been realized. Among the studies that might be possible are: stomatal index as an indicator function of $\mathrm{CO}_{2}$ levels, damage by leaf-mining insects, and others that are not possible at any of the other sites discussed here.

Riediger. At the Riediger site, Fyles (personal commun., 1995) reported that peat and small trees occur in unconsolidated horizontally bedded sand and coarse gravel at the top of the valley wall a few hundred metres to the east of and above the Neoegene sandstone illustrated in Riediger et al. (1984). Riediger applied the name Beaufort Formation to the folded and faulted sandy strata, which belong instead to the Eureka Sound Group. They apparently did not see the woody sands and gravels which we call the Riediger site, which is not surprising because during the 1988 field exploration they were inconspicuous and nearly buried by the ice-sheet margin (see Fyles, 1989). A survey in 2019 by the PoLAR-FIT (Pliocene Landscapes and Arctic Remains-Frozen in Time) field-research team (Gosse et al., 2017) was unable to relocate this site.

Flora 18a lists the taxa that have been identified from the capping deposits of the Riediger site.
A few kilometers away from $18 a$, Flora $18 b$ is quite different. Note, for example, that the $18 \mathrm{~b}$ flora contains both Aracites globosa and abundant, wellpreserved Epipremnum crassum, neither of which occur in the 18a flora. The marked differences between the floras of $18 \mathrm{a}$ and $18 \mathrm{~b}$ suggest that $18 \mathrm{~b}$ is significantly older (Miocene rather than Pliocene?), and this is reason enough for not assigning the name Beaufort Formation to the high terrace sediments because, based on present evidence, the Beaufort Formation is no older than Pliocene.

Flora 18a comprises multiple florules from several thin peats, which are unusually rich in plant fossils. The presence of fragile actinorhizal nodules plus the fact that one of the florules is dominated by a single species of Sphagnum (S. imbricatum Hornsch. ex Russ.) shows that some of the peat beds are autochthonous (Ovenden, 1993, sample 27d). The excellent preservation of the fossil plants and insects might lead one to conclude that the organic sediments of 18 a are Quaternary in age. But the presence of Pinus (Strobus), spruce and larch needles prove this cannot be the case. Pine nuts also occur in the sample, and they are the very large type found in pines such as $P$. albicaulis Engelm and $P$. pumila. The modern range of both of these taxa is far from the Canadian Arctic.

Like several of the Beaufort Formation floras discussed above, the Flora 18a contains Alnus-like nutlets that match no modern alder species. Previously, Matthews (1987) suggested that similar fossils on Meighen Island resembled nutlets described as Alnus tertiaria from the Neogene of Siberia. Another kind of Betulaceous fossil, first found in what is now known as the Ballast Brook Formation, was tentatively referred to Tubela, an extinct genus also described from the Neogene of Russia (Takhtajan, 1982). Several well-preserved fossils from Flora 18a (e.g., Figure 9A) link these two taxa. They show that Alnus-like nutlets formerly called $A$. tertiaria are found inside the enveloping sac of specimens that resemble, and are likely, Tubela. Thus, in this paper all former occurrences that were listed as A. tertiaria type (e.g., Matthews and Ovenden, 1990) are now listed as Tubela sp. The actual taxonomic affinity of these Tubela fossils requires further study. For now, we, like previous authors, place them in the Betulaceae. It is apparent now that the kind of Tubela found in deposits ranging from mid-Miocene to late Pliocene age discussed here, was probably a plant of poorly drained peaty environments.

Many of the taxa from Flora 18b represent plants that grew near or in water. One of these is 


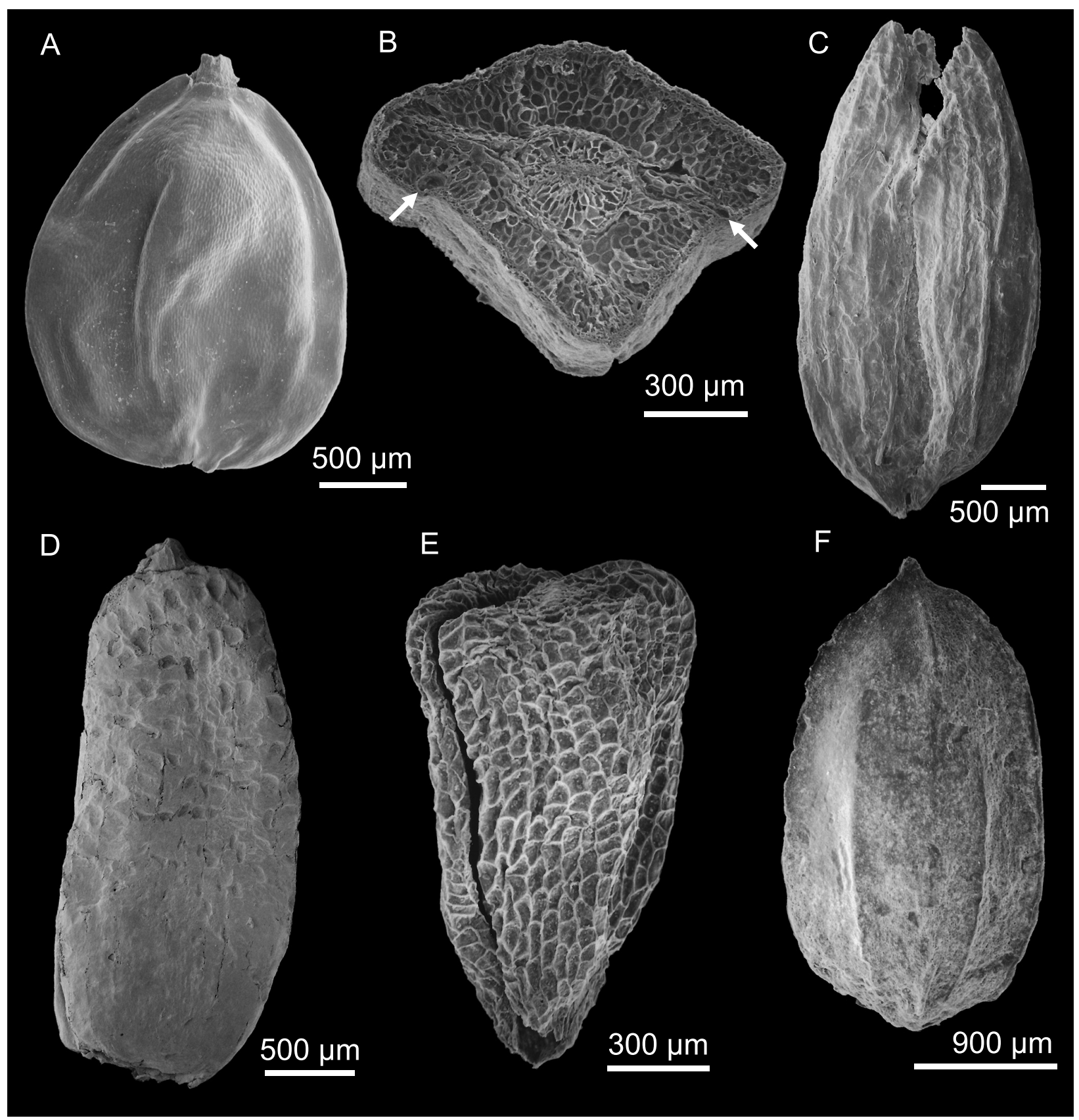

FIGURE 9. SEM micrographs of selected plant fossils from Neogene deposits in the high terrace sections on Ellesmere Island, and Beaufort Formation, Meighen Island. (A) cf. Tubela (Betulaceae), seed, Riediger site, Ellesmere Island, Nunavut, sample FG 89-28a, GSC 141414; a specimen very similar to this one was dissected and found to contain an Alnus-type seed like those referred to A. tertiaria in Matthews, 1987; (B) Picea mariana/rubra type (Pinaceae), cross-section of needle showing resin canals (arrows), Beaver Peat, Ellesmere Island, Nunavut, sample FG88-51b, GSC 141415; (C) Thesium? (Santalaceae), seed, Prince Patrick Island, NWT, Green Bay beds, sample FG 87-10a/2, GSC 141416; (D) Calla sp. (Araceae), seed, Beaver Pond, Ellesmere Island, Nunavut, FG 88-8b, GSC 141417; (E) Unknown seed, Beaver Pond, Ellesmere Island, Nunavut, FG-88-8b, GSC 141418; (F) Comptonia sp. (Myricaceae), seed, Meighen Island, Nunavut, sample MRA 7-25-75-5, GSC 141419. 
Nymphoides. Currently Nymphoides is chiefly a tropical water plant, though some species occur as far north as Newfoundland and central Ontario (Scoggan, 1978-1979; Newmaster et al., 1998; Meades et al., 2000; Desmet and Brouillet, 2013). While the 18b Nymphoides fossils are probably from an extinct species, they nevertheless point to a climate much warmer than present, and probably even warmer than when the Riediger sediments associated with Flora 18a were deposited. Another significant taxon from Flora $18 \mathrm{~b}$ is 'Cyperaceae type A'. It is present in the flora of one other Arctic site (Isachsen, Flora 20), as well as the independently dated late Miocene flora of Canyon Village, Alaska (Flora 5), and in the mid-Miocene Fasterholt Formation of Denmark (Friis, 1985). Thuja and Decodon, neither of which is present in Flora $18 \mathrm{a}$, are present in 18b. Finally, the only Betula fossils in $18 \mathrm{~b}$ are of an arboreal type.

Isachsen. The florules from the Isachsen area, which are small and here considered together (Figure 4, Flora 20), comprise a taxa list most similar to Flora 18b near Riediger. One of the Isachsen samples (FG89-37b) contains abundant Aracites globosa and Ericaceae such as Andromeda, as well as insects typical of swamps and poorly drained sites. No macrofossils of spruce or pine were seen, but wood identified from the site is from Larix. Tubela, the alder-like plant seen at Riediger (Flora 18a) and at many Beaufort Formation sites, is also present. The mosses are the type found in shallow, quiet waters of modern Arctic and boreal regions (Ovenden, 1993). Five species of mosses in one of the samples have their current northern limits in central and northern boreal forests of North America and Eurasia (Ovenden, 1993). This is additional evidence that climate on Ellesmere Island was significantly warmer than today and possibly warmer than at any time during the Quaternary. Supporting this conclusion is the fact that vascular plant macrofossils from Ovenden's sample 10c (Ovenden, 1993) include an abundance of leaf fragments of spruce (also well-preserved cones), larch and Pinus subsection Strobus (with medial resin canals; Matthews and Ovenden, 1990).

Flora 20 also includes fossils from another Isachsen area site (FG8-37c). The florule is dominated by Epipremnum crassum. It also contains Cyperaceae type A, cf. Paliurus, Nymphoides, Myrica arctogale, and two types of Pinus subsection Strobus. Several of these taxa call for an age of at least early Pliocene, possibly late Miocene and a warmer climate than is represented by many of the other high terrace floras and faunas.
This is not the conclusion one would might draw if only pollen data from this location were available. The single sample in Table 1 (37c) is similar to others in the table by its abundant Betula, sufficient spruce pollen to suggest that spruce was growing locally, and, despite the abundance of pine macrofossils in associated samples, practically no pine pollen. It is hardly the type of pollen assemblage to be expected of a Pliocene or Miocene site, and shows once again the potential difficulty of using palynology to discriminate Neogene deposits in the Canadian Arctic.

Rochon. Not all Ellesmere Island sites are of the same elevation. Some are below the high terrace sediments and may be younger than neighbouring sites. This has been confirmed for at least one site by Blake and Matthews (1979; figure 3, BS77-240), where the Quaternary age was confirmed by finite ${ }^{14} \mathrm{C}$ dates. At that site, the taxa present suggests only marginally warmer climate in a tundra environment. Other low elevation sites, such as the Rochon site west of Vendom Fjord (Figure 4, Flora 19a), remain of indefinite age.

At the Rochon site several metres of autochthonous peat are exposed $30 \mathrm{~m}$ below the regional upper terrace surface and $220 \mathrm{~m}$ above sea level. One spruce needle was found in the Rochon peats, which probably represents a tree that grew very near the site of deposition. The presence of spruce on Ellesmere Island means these peats are almost certainly not younger than Gelasian. Strangely there is no sign of Larix, usually the dominant conifer in terms of needle remains at most high terrace sites. This suggests deposition came after the time when larches were the dominant conifers of the Arctic. Also absent are fossils of pine, in contrast to a nearby high terrace site (Figure 4, Flora 19b) where one of the first fossils recovered was Pinus (Strobus). As such, although the Rochon site peats may have formed in a climate comparable to the late Neogene deposits discussed throughout, the typical elements that comprised the Neogene Arctic flora were at least regionally extinct.

Fosheim Peninsula. The Fosheim Peninsula of Ellesmere Island contains several important Neogene macrofossil sites (Matthews and Fyles, 2000). In fact, study of the fossils from these sites is instructive not only for what they reveal about Neogene environment in the region, but also what they teach us about distinguishing Quaternary deposits from those of Neogene age. In the High Arctic this is often a difficult task because Neogene fossils can easily be rebedded into younger sedi- 
ments and Neogene fossils are as well preserved as those of Quaternary age.

Here we mention three floras, Remus Creek (Flora 24), South Bay (25), and Fosheim Dome (26) that illustrate some of the issues discussed in conjunction with other floras from Ellesmere Island and the Beaufort Formation on Meighen, Prince Patrick, and Banks Islands (Matthews and Fyles, 2000). All three of the Fosheim floras contain taxa that are typical of the Beaufort Formation and lack the taxa suggestive of a Miocene age.

The Remus Creek flora (24) contains fossils of Pinus (Strobus), Physocarpus, and Comptonia seen in typical high terrace sediments. Seeds of the latter are especially abundant and exhibit a great range of variation in both size and shape and constitute a valuable reference collection if an attempt is ever made to study the systematics of Neogene Comptonia. One of the Comptonia seeds possesses remnants of the enclosing bracts and looks very similar to specimens of the extant species C. peregrina (L.) Coult. A similar form also occurs in one of the Ballast Brook Beaufort samples. Together they show that the modern form may have a long lineage and that it is not derived from any of the late Neogene fossil species. A few seeds seem to have suffered damage from some type of boring insect. Four of the moss species are widespread in boreal and alpine regions today (Ovenden, 1993).

The Fosheim Dome sites occur along the north wall of a small valley between Fosheim Dome and the Sawtooth Mountains (Fyles, personal commun., 1992). The fossil flora (26) is dominated by Dryas leaves, but of the type illustrated in Figure 8 rather than $D$. integrifolia, the common species in the Arctic today. This probably means that the Dome sites are no younger than early Pleistocene. Extreme rarity of conifer fossils or of any insects associated with forests also shows that the Fosheim Dome sites may not be as old as Remus Creek (24) and South Bay (25) or the Beaufort Formation. However, one of the mosses in the Fosheim Dome assemblage (Pleurozium schreberi (Willd. ex Brid.) Mitt.) is a Subarctic to boreal species. So, although trees were rare or did not grow near this site, they may have in more southerly locations on Ellesmere Island, indicating a climate warmer than today. The temperature estimate from mutual climate range of beetles is Tmax-mean of $10.7^{\circ} \mathrm{C}, 8.3^{\circ} \mathrm{C}$ warmer than present, and Tmin-mean $-28.4^{\circ} \mathrm{C}, 13^{\circ} \mathrm{C}$ warmer than present (Elias and Matthews, 2002). Whether this was in latest Pliocene time or during an early Quaternary interglaciation is not presently known.

\section{TAXA WITH BIOSTRATIGRAPHIC SIGNIFICANCE}

The most valuable taxa for dating and correlation are those that can be recognized from several types of remains, e.g., pollen, seeds, fruits and wood or foliar characteristics for plants. Obviously, this criterion is seldom met because of differences in the way these various types of plant parts are preserved and dispersed or the level at which particular types of fossils can be identified. The First Appearance Datum (FAD) and Last Appearance Datum (LAD) for taxa found in the Subarctic/Arctic region of North America is an evolving construct, subject to change as new floras are discovered and documented. Nevertheless, we now feel that enough such floras have been studied and dated to allow the flora and fauna to be used for regional dating and correlation. Following are comments on the biostratigraphic implications of selected plants.

\section{Plants}

Pinus. Foliar remains of certain conifers are valuable for identifying Neogene deposits. An emerging rule of thumb is that any Arctic sample containing pine needles, especially of Pinus (Strobus), must be of pre-Quaternary age, unless the needles and needle fragments are rebedded from older deposits. The preservation of the needles, especially if they occur in fascicles (i.e., still attached to each other at their base) can often be used to evaluate this possibility, as rebedded needles are easily damaged and particularly unlikely to occur in fascicles.

Some pine seeds can be referred to Pinus groups on the basis of their size, presence, or absence of adhering wings and other features of the seed (Critchfield, 1986). Combinations of these characters show that Pinus pumila (or a closely rated extinct relative) occurred on Ellesmere Island during the Pliocene and likely also on Meighen Island. A shrub pine like $P$. pumila may have been a common tree in the Canadian Arctic Archipelago region prior to the Quaternary.

Most pine wood from Neogene sites is referred to as the 'Pinus strobus' type, which is potentially misleading because one might conclude that pines like the present eastern or western white pine once grew in the Canadian Arctic. The fact that most of the pine seeds found to date are much larger than the seeds of either of these species suggests this was not the case. Much of the Stro- 
bus-type wood probably refers either to one of the species previously assigned to 'subsection Cembrae' (Little and Critchfield, 1969) or a species similar to $P$. pumila.

In its more southerly range during the Quaternary, pine pollen is usually abundant even if pine is only a minor component of the regional flora. For some reason this situation seems to be the reverse with Neogene samples because, as Table 1 and the comments here show, samples containing pine macrofossils have yielded very low percentages of pine pollen. This shows that we should not rely on pollen spectra alone to determine whether pine was present in the region.

The presence of pine may also be indicated by fossils of insects which feed exclusively on it. The weevil Dryophthorus americanus Bedel, 1885 feeds on white pines; therefore, its occurrence in a sample constitutes reasonable evidence that some type of Pinus (Strobus) Section Quinquefoliae was growing in a region. Dryophthorus americanus has been identified at Lava Camp (1) and Lost Chicken mine (2).

Larix. Foliar remains of Larix are nearly ubiquitous in Neogene samples. Usually they outnumber spruce, which is different from the situation in Quaternary age samples from Subarctic regions where both spruce and larch grow. Even though they cannot at this time be referred to species, presence of abundant larch needles is a sure indication that a site was within regional larch tree line. Furthermore, because the last occurrence of larch in the Canadian Arctic Archipelago was at approximately early Pleistocene, any site from farther north containing an abundance of larch fossils is not likely to be younger than latest Pliocene-earliest Pleistocene.

Female cones of Larix provide more definitive characters for identification than foliar remains. Most of the relatively long-bracted Larix cones found at several Arctic sites probably represent the extinct species L. groenlandii. Larix groenlandii probably disappeared from the Canadian Arctic prior to the time of the last appearance of all larches in the archipelago. The extant larch species L. laricina (Du Roi) K. Koch grew on southern Banks Island during earliest Quaternary time. Hence any fossil flora containing the long-bracted type cones is quite likely to be no younger than early Pleistocene.

Larix pollen is never abundant, even in samples from modern sites where larch is the dominant tree. This and the fact that Larix pollen is very similar to pollen of Pseudotsuga means that pollen data provide little help in determining the former presence or abundance of larch at a specific site.

Metasequoia and Glyptostrobus. Pollen from the Dawn redwood (Metasequoia) is difficult to delineate from several related taxa, including Glyptostrobus, but its leaves, seeds, and cone fragments are readily identifiable. This is fortunate because in Arctic/Subarctic North America the LAD for Metasequoia is approximately $11 \mathrm{Ma}$ (late Miocene middle-Homerian stage; Wolfe, 1994). Any site containing Metasequoia macrofossils, unless rebedded from an older site, implies an age of Miocene or older.

Another conifer which, like Metasequoia, today grows wild only in Asia but was formerly widely distributed, is water pine or Glyptostrobus. It survived until the Pliocene in North America (Wolfe, 1994), possibly disappearing earlier in northern regions. This means that any Arctic site yielding Glyptostrobus fossils is probably no younger than early Pliocene. All the high terrace sites on Ellesmere Island, the Beaufort Formation on Meighen Island, and Beaufort localities on other islands appear to postdate the extinction of Glyptostrobus in Arctic North America.

Epipremnum. Despite some uncertainty as to its actual affinities, Epipremnum crassum is an important taxon for regional correlation because it is easily recognized and the seeds are quite indurate (Gregor and Bogner, 1984). This last-named characteristic also means that it is likely to be included as a rebedded fossil in deposits that post-date its regional extinction. Occasionally E. crassum seeds possess a fragile, black coating, considered by Reid and Reid (1915) to be part of the fruit rather than the seed. Several of the florules discussed here (from Ballast Brook Formation, Unit 4, some of the peats at Upper Ramparts locality 90-1, two sites in the high terrace sediments on Ellesmere Island; Lost Chicken mine, and Unit B at Bluefish exposure) have yielded such fossils. They are probably not rebedded; hence, we conclude that $E$. crassum was growing at those sites at about the time of deposition.

Epipremnum crassum occurs in dated, late Miocene deposits in central Alaska, and as indicated above may have survived until $3 \mathrm{Ma}$ in east central Alaska (Lost Chicken - see above) and possibly to just prior to $3.2 \mathrm{Ma}$ in the Canadian High Arctic (Meighen Island below the marine unit). It is conspicuously absent in all Meighen Island deposits above the marine unit, i.e., by about 3.2 $\mathrm{Ma}$; is also absent from the Beaver Pond deposits on Ellesmere Island, $\sim 4 \mathrm{Ma}$, and from the $2-2.5 \mathrm{Ma}$ 
deposits at Kap København on northern Greenland. Based on all sites studied to date, it is unlikely that any Arctic deposit containing well-preserved $E$. crassum is younger than the early part of the late Pliocene.

In northern Europe Epipremnum crassum last appears in deposits of early Pliocene (Brunssumian) age (Zagwijn, 1990). The last appearance datum elsewhere is less well defined, and its extinction at high latitudes likely diachronous. If, as some suggest, Epipremnum belongs with the Araceae, its pollen is unlikely ever to be recognized in pollen spectra. Foliar remains have not been found.

Today, species of Epipremnum are known from Asia and the Pacific, and are predominantly tropical in distribution (Gregor and Bogner, 1984), but the associated plants at Lost Chicken and at other sites discussed here that also contain Epipremnum remains show that Epipremnum was formerly a plant of northern North American hardwood and coniferous forests. Other sites in the Canadian Arctic reveal that it probably grew in poorly drained openings within such forests (see Ellesmere Island high terrace sediments).

Aracites. Another extinct plant of disputed affinities, but like Epipremnum crassum possibly belonging with the arums (Araceae), is Aracites globosa. The LAD for Aracites in both northern Europe and the North American Subarctic (Labrador) is apparently early Quaternary, or younger, because it has been found in Quaternary deposits in Labrador and Finland (Aalto and Hirvas, 1987; Klassen et al., 1988). A distinctive specimen of Aracites occurs at the $305 \mathrm{~m}$ level of the Taglu borehole in the Mackenzie Delta in magnetically reversed sediments probably representing the Matuyama chron (Dallimore and Matthews, 1997). The $30 \mathrm{~m}$ level of the Taglu borehole overlies two diamictons, which suggests that Aracites may have survived two early Quaternary continental glaciations (Duk-Rodkin et al., 2004).

Aracites (as A. globosa) occurs in the $2.5 \mathrm{Ma}$ Kap København Formation in northern Greenland (Bennike, 1990; Pedersen et al., 2019). However, it is conspicuously absent from the Worth Point flora (approx. 1.8 Ma) even though Worth Point peats, on the basis of their moss, seem to represent the type of environment in which Aracites would be expected (Matthews and Ovenden, 1990). Like Epipremnum, Aracites is a taxon that is essentially invisible in the pollen record. It is known only from seeds and its foliar characteristics are unknown.
Cyperaceae. Fossils representing the family Cyperaceae occur in most Neogene samples discussed here, but so far only two taxa-Dulichium and the one referred to as 'Cyperaceae type A'have evident biostratigraphic significance. A single species of Dulichium now grows in eastern North America, but the genus had an Holarctic distribution during the Neogene, persisting until the late Pleistocene in Europe (Tralau, 1959). The bestpreserved fossils from sites in the North American Arctic come from the mid-Miocene Mary Sachs gravel (Flora 10) on southern Banks Island. These fossils probably represent the extinct species $D$. vespiforme C \& E. Reid (Zagwijn, personal commun., 1987), which has been described from Neogene deposits in Europe. The same species appears to be present in the Ballast Brook Formation on northern Banks Island (11a) and at the West River (22) on the northern mainland. Rare specimens, probably rebedded from the Ballast Brook Formation, occur in the lower part of the Beaufort Formation at Ballast Brook. The genus is not known from any other Beaufort Formation flora or from the high terrace sediments on Ellesmere Island. It appears that Dulichium may have become extinct in Arctic North America prior to the start of the Pliocene. Therefore, when found as a fossil at an Arctic North American site, it suggests an age no younger than late Miocene.

Distinctive fossils referred to as 'Cyperaceae type A' occur at only three of the sites discussed here - the Canyon Village (Flora 5) in eastern Alaska, and Riediger (18b) and Isachsen (20) on Ellesmere Island. At one of these - the Canyon Village site in eastern Alaska - it was found in beds dated to $6.4 \mathrm{Ma}$ by an associated volcanic tephra (Fouch et al., 1994). A similar taxon appears in mid-Miocene deposits in northern Europe (Friis, 1985), and to our knowledge has not been reported from any of the many European Pliocene sites. We suggest, therefore, that high latitude North American sites containing this taxon are no younger than late Miocene.

Myrica. Myrica pollen is a consistent, if minor, component of Neogene pollen assemblages in both northern North America and northern Eurasia. This is true as well for Myrica macrofossils. Many of the sites discussed here contain endocarps of the Myrica (Gale) type. However, the best-preserved specimens clearly represent a different species than the extant M. (Gale) gale. Here we refer them to the extinct species, Myrica arctogale, first described from the Kap København Formation in northern Greenland (Bennike, 1990). The LAD of 
$M$. arctogale is not known, but presence of its fossils in this region is at least a strong hint that the host sediments are no younger than Kap København - earliest Pleistocene.

Poorly preserved specimens $M$. arctogale (e.g., lacking the lateral lobes seen in figure $6 \mathrm{~h}$ of Matthews et al., 1990b) cannot be distinguished from similarly preserved remains of $M$. gale. Fossils of $M$. gale are extremely rare, even in Quaternary sediments from the Subarctic zone where $M$. gale reaches its northern limit. Thus, one may reasonably assume that any Arctic fossil flora containing Myrica endocarps lacking lateral lobes due to poor preservation is more than likely earliest Pleistocene or older. As with many such conclusions drawn in this section, this one is also tempered somewhat by the fact that Myrica (Gale) type endocarps are thick walled and quite likely to survive recycling from older deposits.

Comptonia. Another plant related to Myrica, and found in many of the fossil assemblages discussed here, is Comptonia. Endocarps are the most common fossil. They are well-adapted for transport in water and rugged enough to survive rebedding from older units, so caution should be used in relying on them alone for dating.

There is one extant species of Comptonia in North America. It is common in openings within the Acadian forest of eastern Canada. However, the extant species, C. peregrina, is rare as a fossil in Arctic Neogene assemblages. Instead, the fossils, which are abundant in some samples, exhibit a variety of morphotypes, representing perhaps several species or alternatively, one extinct highly variable species.

In the Canadian High Arctic Comptonia fossils occur in floras dated as late as late Pliocene (approximately $3 \mathrm{Ma}$ ), but are conspicuously absent from dated younger floras (or sites presumed to be of that age by their content of other fossils). Thus, for the time being it seems reasonable to assume that the LAD for the extinct Comptonia species in Arctic Canada and Alaska is late, but not latest, Pliocene.

Juglandaceae and Magnoliaceae. Carya and Juglans (Juglandaceae) have distinctive pollen types and are important components of Paleogene and early Neogene Arctic pollen floras. Juglans nuts have been recorded in the Eocene in the Arctic (Wilson et al., 2006) and continue through into the Neogene, with Juglans and Carya nuts occurring occasionally in early Neogene sediments (Hills et al., 1974; Hills, 1975; Manchester, 1987) from Arctic and Subarctic regions. The presence of abundant nuts at a Neogene site, as seen at certain parts of the Duck Hawk Bluffs exposure on southern Banks Island (Hills et al., 1974), provides substantial proof that Carya or Juglans had been growing nearby. In contrast the presence of a few percent of pollen is less compelling, especially in the Canadian Arctic where such pollen is likely to be rebedded from the Paleogene Eureka Sound group.

Tulip tree or Liriodendron (Magnoliaceae) has a present regional distribution similar to that of Juglans, if anything Liriodendron being somewhat more sensitive to cold temperatures. Liriodendron achenes are more likely to occur in alluvial deposits than nuts of Juglans, and we submit that an occurrence of Liriodendron fossils at a site has the same general biostratigraphic implications as do macrofossils of Juglans and probably Carya, implying an age no younger than mid-Miocene.

Polygonaceae. Oxyria and Rumex, both in the family Polygonaceae, have distinctive pollen morphology. Their macrofossils are also unique and easily identified-Oxyria to the species level. An emerging pattern is that Oxyria fossils only occur in Arctic samples that are Pliocene or younger (see Table 2). A distinctive type of Rumex (figure 6a of Matthews et al., 1990b, Rumex sp., Appendix 1) is now known from several Neogene floras. Its affinities with the extant species are not clear, but it probably does not represent one of the current northern species. Judging by its distribution in floras from the Beaufort Formation, its LAD is likely no younger than late Pliocene.

Lythraceae. Seeds referred by us to the extinct Iythraceous genera Microdiptera/Mneme occur in the Ballast Brook Formation (11a) and Mary Sachs gravel (10). As indicated above, those from the Mary Sachs gravel appear intermediate, sharing characters ascribed to each of the two genera. The few specimens from the Ballast Brook Formation are more like Microdiptera. Nevertheless, until a detailed study of all fossil material is conducted, we believe it prudent to group Mneme, Microdiptera, and/or Diclidocarya as the 'Mneme/Microdiptera type'.

A few poorly preserved Mneme/Microdiptera type seeds have been found in the Beaufort Formation deposits on northern Banks Island and Prince Patrick Island as well as at the Canyon Village site in eastern Alaska. They are probably rebedded from older deposits, but if not, they suggest that the LAD of Mneme/Microdiptera in the North American Arctic may be as young as early Pliocene. 
TABLE 2. Comparison of late Pliocene and early Pleistocene Florules.

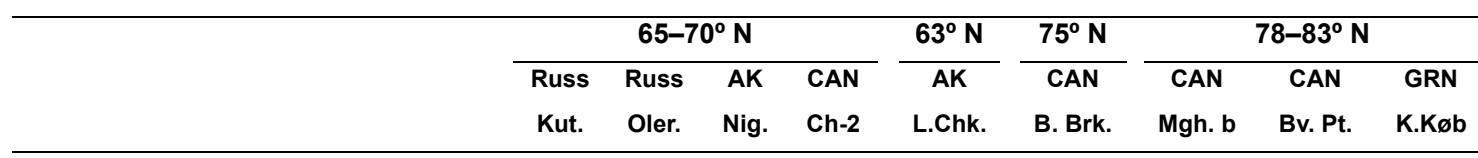

\section{Tracheophyta}

Lycopodiophytina

Selaginellaceae

Selaginella

Polypodiophytina

Equisetaceae

Equisetum

Spermatophytina

Pinopsida

Taxaceae

Taxus

Pinaceae

Abies

Larix

Picea sp.

Pinus (Pinus) '2-needle undiff.'

Pinus (Strobus) sect. Quinquefoliae '5needle undiff.'

Cupressaceae

Thuja

\section{Magnoliopsida}

Typhaceae

Sparganium

Potamogetonaceae

Potamogeton

Scheuchzeriaceae

Scheuchzeria

Juncaginaceae

Triglochin

Poaceae

Glyceria

Cyperaceae

Carex

Dulichium

Eleocharis

Eriophorum

Scirpus

Araceae

Aracites globosa (C. \& E. Reid) Benn.

Epipremnum crassum C. \& E. Reid

Epipremnum small type 
FLETCHER ET AL.: ARCTIC MACROFLORA

Table 2 (continued).

\begin{tabular}{|c|c|c|c|c|c|c|c|c|c|}
\hline & \multicolumn{4}{|c|}{$65-70^{\circ} \mathrm{N}$} & \multirow{2}{*}{$\begin{array}{c}63^{\circ} \mathrm{N} \\
\text { AK } \\
\text { L.Chk. }\end{array}$} & \multirow{2}{*}{$\begin{array}{c}75^{\circ} \mathrm{N} \\
\text { CAN } \\
\text { B. Brk. }\end{array}$} & \multicolumn{3}{|c|}{$78-83^{\circ} \mathrm{N}$} \\
\hline & $\begin{array}{l}\text { Russ } \\
\text { Kut. }\end{array}$ & $\begin{array}{l}\text { Russ } \\
\text { Oler. }\end{array}$ & $\begin{array}{c}\text { AK } \\
\text { Nig. }\end{array}$ & $\begin{array}{l}\text { CAN } \\
\text { Ch-2 }\end{array}$ & & & $\begin{array}{c}\text { CAN } \\
\text { Mgh. b }\end{array}$ & $\begin{array}{l}\text { CAN } \\
\text { Bv. Pt. }\end{array}$ & $\begin{array}{c}\text { GRN } \\
\text { K.Køb }\end{array}$ \\
\hline \multicolumn{10}{|l|}{ Juncaceae } \\
\hline Juncus/Luzula & & & & & & & + & + & + \\
\hline \multicolumn{10}{|l|}{ Zingiberaceae } \\
\hline $\begin{array}{l}\text { Spirematospermum wetzleri (Heer) M. } \\
\text { Chandler ex Kirchheim. }\end{array}$ & & & & & & + & & & \\
\hline \multicolumn{10}{|l|}{ Salicaceae } \\
\hline Populus & & & + & & & & + & & \\
\hline Salix & & & + & + & & + & + & + & + \\
\hline \multicolumn{10}{|l|}{ Myricaceae } \\
\hline Comptonia & & & & & & + & + & + & \\
\hline Myrica (Gale) arctogale Benn. & & & & $?$ & + & $?$ & + & + & + \\
\hline \multicolumn{10}{|l|}{ Betulaceae } \\
\hline $\begin{array}{l}\text { Alnus alnobetula subsp. crispa (Aiton) } \\
\text { Raus type }\end{array}$ & & & + & & & & + & + & + \\
\hline Alnus incana (L.) Moench type & & & & + & & + & + & & \\
\hline Betula dwarf shrub & & & + & & & + & + & + & + \\
\hline Betula & & & & & & & & & + \\
\hline Betula arboreal type & & & + & + & & + & + & & \\
\hline Betula apoda P.I. Dorof. in Takht. type & & & & & & + & & & \\
\hline Tubela & & & & & & & + & & \\
\hline \multicolumn{10}{|l|}{ Polygonaceae } \\
\hline Oxyria & & & & & & & + & + & + \\
\hline Polygonum & + & & & & & + & + & + & + \\
\hline Rumex & & & & & & + & + & & + \\
\hline \multicolumn{10}{|l|}{ Amaranthaceae } \\
\hline Chenopodium & & & & & & + & + & & \\
\hline Corispermum & & & & & & & $?$ & & \\
\hline \multicolumn{10}{|l|}{ Montiaceae } \\
\hline Claytonia & $?$ & & & & & + & & & \\
\hline \multicolumn{10}{|l|}{ Caryophyllaceae } \\
\hline Arenaria & & & & & & & & & + \\
\hline Melandrium & & & & & & & & & + \\
\hline Silene & & & & & & & + & & \\
\hline Stellaria & & & $?$ & & & & + & & + \\
\hline Genus? & & & & & & & + & + & + \\
\hline \multicolumn{10}{|l|}{ Ceratophyllaceae } \\
\hline Ceratophyllum demersum $\mathrm{L}$. & + & & & & & & & & \\
\hline Ceratophyllum submersum L. & + & + & & & & & & & \\
\hline \multicolumn{10}{|l|}{ Cabombaceae } \\
\hline Brasenia & & + & & & & & & & \\
\hline \multicolumn{10}{|l|}{ Nymphaeaceae } \\
\hline Nuphar & + & + & & & & + & + & + & + \\
\hline Nymphaea & + & & & & & + & & & \\
\hline
\end{tabular}


Table 2 (continued).

\begin{tabular}{|c|c|c|c|c|c|c|c|c|c|}
\hline & \multicolumn{4}{|c|}{$65-70^{\circ} \mathrm{N}$} & \multirow{2}{*}{$\begin{array}{c}63^{\circ} \mathrm{N} \\
\text { AK } \\
\text { L.Chk. }\end{array}$} & \multirow{2}{*}{$\begin{array}{c}75^{\circ} \mathrm{N} \\
\text { CAN } \\
\text { B. Brk. }\end{array}$} & \multicolumn{3}{|c|}{$78-83^{\circ} \mathrm{N}$} \\
\hline & $\begin{array}{l}\text { Russ } \\
\text { Kut. }\end{array}$ & $\begin{array}{l}\text { Russ } \\
\text { Oler. }\end{array}$ & $\begin{array}{l}\text { AK } \\
\text { Nig. }\end{array}$ & $\begin{array}{l}\text { CAN } \\
\text { Ch-2 }\end{array}$ & & & $\begin{array}{c}\text { CAN } \\
\text { Mgh. b }\end{array}$ & $\begin{array}{l}\text { CAN } \\
\text { Bv. Pt. }\end{array}$ & $\begin{array}{l}\text { GRN } \\
\text { K.Køb }\end{array}$ \\
\hline \multicolumn{10}{|l|}{ Ranunculaceae } \\
\hline Anemone & & & & & & & & & + \\
\hline Caltha & & & + & & & + & $?$ & & \\
\hline Ranunculus & + & + & + & + & & + & & & + \\
\hline Ranunculus lapponicus L. type & & & + & & & + & + & + & \\
\hline \multicolumn{10}{|l|}{ Papaveraceae } \\
\hline Papaver & & & & & & & + & & + \\
\hline \multicolumn{10}{|l|}{ Cleomaceae } \\
\hline Cleome & & & & & & + & & & \\
\hline \multicolumn{10}{|l|}{ Brassicaceae } \\
\hline Arabis & & & & & & & & & + \\
\hline Rorippa & & & & + & & & + & & \\
\hline \multicolumn{10}{|l|}{ Crassulaceae } \\
\hline Sedum sp. & & & & & & & & & + \\
\hline \multicolumn{10}{|l|}{ Saxifragaceae } \\
\hline Chrysosplenium & & & + & & & & & & \\
\hline Mitella & & & & & & & + & & \\
\hline Saxifraga oppositifolia L. & & & & & & & + & + & \\
\hline \multicolumn{10}{|l|}{ Rosaceae } \\
\hline Comarum palustre L. type & & + & & + & + & + & + & + & + \\
\hline Crataegus & & & & & & & $\mathrm{cf}$ & & \\
\hline Dryas & & & + & + & & & + & + & + \\
\hline Physocarpus & & & & & & + & + & + & \\
\hline Potentilla & & & + & & + & + & + & + & + \\
\hline Potentilla norvegica L. type & & & + & & & + & & cf & \\
\hline Rosa & & & $?$ & & & & & & \\
\hline Rubus & & & & & & + & + & & + \\
\hline Rubus idaeus L. & & + & & & & + & + & + & \\
\hline Sorbus & & & & & & & $?$ & & \\
\hline \multicolumn{10}{|l|}{ Fabaceae } \\
\hline Hedysarum & & & & & & & + & & + \\
\hline \multicolumn{10}{|l|}{ Geraniaceae } \\
\hline Erodium & & & & & & & & & + \\
\hline \multicolumn{10}{|l|}{ Empetraceae } \\
\hline Empetrum nigrum $\mathrm{L}$. & & & + & + & & & + & + & + \\
\hline \multicolumn{10}{|l|}{ Rhamnaceae } \\
\hline Paliurus & & & & & & & & + & \\
\hline \multicolumn{10}{|l|}{ Hypericaceae } \\
\hline Hypericum & & & & & & + & & & \\
\hline
\end{tabular}


FLETCHER ET AL.: ARCTIC MACROFLORA

Table 2 (continued).

\begin{tabular}{|c|c|c|c|c|c|c|c|c|c|}
\hline & \multicolumn{4}{|c|}{$65-70^{\circ} \mathrm{N}$} & \multirow{2}{*}{$\begin{array}{c}63^{\circ} \mathrm{N} \\
\text { AK } \\
\text { L.Chk. }\end{array}$} & \multirow{2}{*}{$\begin{array}{c}7^{\circ} \mathrm{N} \\
\text { CAN } \\
\text { B. Brk. }\end{array}$} & \multicolumn{3}{|c|}{$78-83^{\circ} \mathrm{N}$} \\
\hline & $\begin{array}{l}\text { Russ } \\
\text { Kut. }\end{array}$ & $\begin{array}{l}\text { Russ } \\
\text { Oler. }\end{array}$ & $\begin{array}{l}\text { AK } \\
\text { Nig. }\end{array}$ & $\begin{array}{l}\text { CAN } \\
\text { Ch-2 }\end{array}$ & & & $\begin{array}{c}\text { CAN } \\
\text { Mgh. b }\end{array}$ & $\begin{array}{l}\text { CAN } \\
\text { Bv. Pt. }\end{array}$ & $\begin{array}{c}\text { GRN } \\
\text { K.Køb }\end{array}$ \\
\hline \multicolumn{10}{|l|}{ Lythraceae } \\
\hline $\begin{array}{l}\text { Decodon globosus (E.M. Reid) Nikitin } \\
\text { type }\end{array}$ & & & & & & + & & + & \\
\hline Mneme/Microdiptera type & & & & & & + & & & \\
\hline \multicolumn{10}{|l|}{ Plantaginaceae } \\
\hline Hippuris & + & + & + & + & & + & + & + & + \\
\hline \multicolumn{10}{|l|}{ Haloragaceae } \\
\hline Myriophyllum & + & & & & & + & & & \\
\hline \multicolumn{10}{|l|}{ Araliaceae } \\
\hline Aralia & & & & & & + & & & \\
\hline \multicolumn{10}{|l|}{ Apiaceae } \\
\hline Cicuta & & & & & + & & & & \\
\hline \multicolumn{10}{|l|}{ Cornaceae } \\
\hline Cornus sericea subsp. sericea L. type & & & & & & + & & & + \\
\hline Cornus & & & + & + & & + & + & + & + \\
\hline \multicolumn{10}{|l|}{ Ericaceae } \\
\hline Andromeda & & & + & + & + & + & + & & + \\
\hline Arctostaphylos & & & + & & & & & & + \\
\hline Cassiope & & & & & & & + & & + \\
\hline Chamaedaphne & & & + & + & + & + & + & + & \\
\hline Ledum & & & & & & & & $?$ & + \\
\hline Oxycoccus & & & & & & & + & + & + \\
\hline Vaccinium & & & $?$ & & & + & + & & + \\
\hline \multicolumn{10}{|l|}{ Gentianaceae } \\
\hline Menyanthes trifoliata L. & + & + & + & + & + & + & + & + & + \\
\hline Menyanthes small form & & & & + & & + & + & + & \\
\hline Nymphoides & & & & & & + & + & & \\
\hline \multicolumn{10}{|l|}{ Verbenaceae } \\
\hline Verbena & & & & & & + & & & \\
\hline \multicolumn{10}{|l|}{ Valerianaceae } \\
\hline Valeriana & & & & & & & cf. & & \\
\hline \multicolumn{10}{|l|}{ Lamiaceae } \\
\hline Lycopus & & & & & & + & & & \\
\hline \multicolumn{10}{|l|}{ Solanaceae } \\
\hline Solanum/Physalis type & & & & & & + & & & \\
\hline \multicolumn{10}{|l|}{ Scrophulariaceae } \\
\hline Linaria & & & & & & & & & + \\
\hline \multicolumn{10}{|l|}{ Adoxaceae } \\
\hline Sambucus & & & & + & + & + & & & \\
\hline Viburnum & & & & & & & $?$ & & + \\
\hline
\end{tabular}


Table 2 (continued).

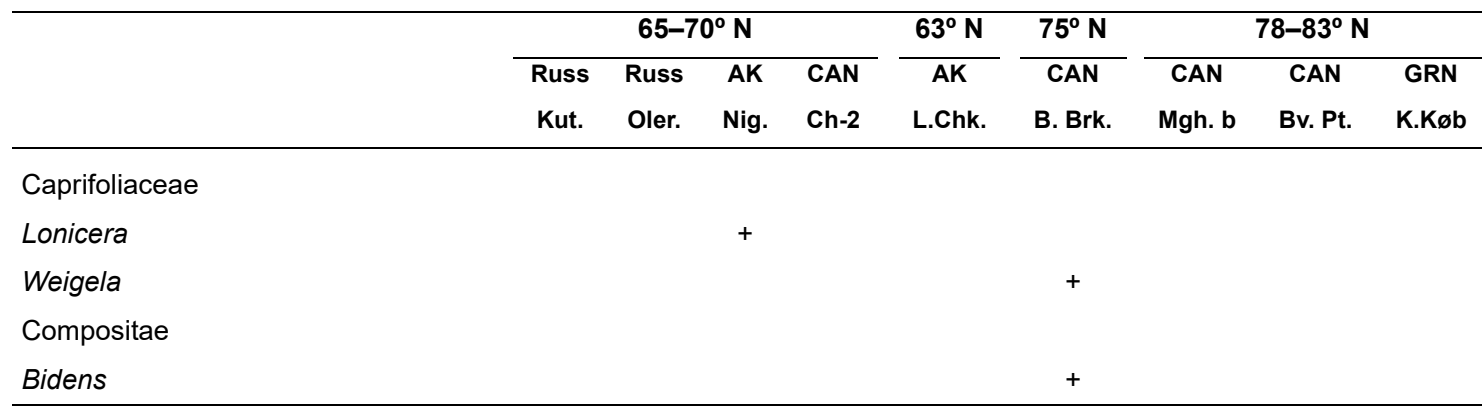

"Russ Kut."=Kutuyakh Suite, Krestovka Section, Kolyma Lowland; modified from Sher et al., 1979.

"Russ Oler."=Lower Olerian Suite Krestovka Section and others in Kolyma Lowland; modified from Sher et al., 1979.

"AK Nig."=Niguanak Section, Alaskan North slope (Flora 3).

"CAN Ch2"=Ch'ijee's Unit 2, northern Yukon, Canada (Flora 8b).

"AK L.Ch."=Lost Chicken site, Alaska (Flora 2); adapted from Matthews et al., 2003

"CAN BBrk"=Beaufort Fm. at Ballast Brook (Flora 11b), northern Banks Island, NWT.

"CAN Mgh b"=Meighen Island, NWT, Canada (Flora 15b); from unit above marine sediments.

"CAN Bv.Pt."=Beaver Peat, Strathcona Fiord, Ellesmere Island (Flora 16).

"GRN K.Køb"=Kap København Formation, northern Greenland (Bennike, 1990).

Decodon, another lythraceous genus, is often present in Neogene assemblages from northern North America. Though Decodon now grows in eastern North America, its last occurrence in Arctic regions was undoubtedly during the Pliocene. Wolfe and Tanai (1980) recorded foliar remains of Decodon from the Miocene Seldovia Point Formation of south-central Alaska, and we show here that it is present in mid-Miocene deposits in the Arctic.

Caprifoliaceae. Caprifoliaceae pollen, particularly Diervilla, is recorded in many Neogene pollen floras of North America and Eurasia. Macrofloral remains of both Diervilla and Weigela occur in Arctic Neogene assemblages, including those here, but to date Diervilla has only been found in presumed Miocene floras. On the other hand, Weigela macroremains occur in deposits ranging from midMiocene to Pliocene, and since its pollen cannot be distinguished from Diervilla, some of the Pliocene pollen reports of Diervilla may actually represent Weigela. This is further confused by phylogenetic studies that suggest Diervilla and Weigela diverged in the earliest Pliocene (Donoghue et al., 2001) and genetic studies (Kim and Kim, 1999) that suggest Weigela is not monophyletic, and should include Diervilla, despite morphological differences. Here, identification follows traditional morphological distinctions.

To date, Weigela has not been found in the Beaufort Formation on Meighen Island (15a,15b), but it does occur in the Beaufort Formation on northern Banks Island (11b) and in some of the Beaufort florules from Prince Patrick Island (12a; Matthews et al., 1990b; Fyles et al., 1994). A simi- lar pattern is exhibited by Sambucus. Unless the fossils are rebedded from older deposits, any find of Sambucus or Weigela from a Subarctic/Arctic site is evidence for a pre-Quaternary age.

\section{Taxa Cohorts}

All the above comments regarding biostratigraphic implications are based on single taxa or groups of closely related taxa. Clearly, the power of conclusions relating to age and correlation is higher when several different types of fossils are used. This is why taxa cohorts are important. Cohorts differ from assemblages of fossils in that they represent certain collections of taxa that may form only a part of an assemblage. Enough sites have now been studied to allow recognition of several such cohorts.

For example, Aracites, Pinus (Strobus), Myrica arctogale, Oxyria, and Dryas form a cohort. When it occurs in an assemblage it implies a Pliocene age. Insect fossils might well be considered as elements of such a cohort. Two forms that would be obvious constituents of the above-mentioned cohort are the extinct form Diacheila matthewsi Böcher, 1995 and Notiophilus cf. aeneus.

\section{CORRELATION AND DATING}

The basis for all conclusions bearing on Neogene vegetation and faunal change in the Arctic is a reasonable knowledge of the age of various key floras and faunas of the region or other areas within the same climate zone. When these floras and faunas are from sites that are independently dated, either by radiometric methods, geomagne- 


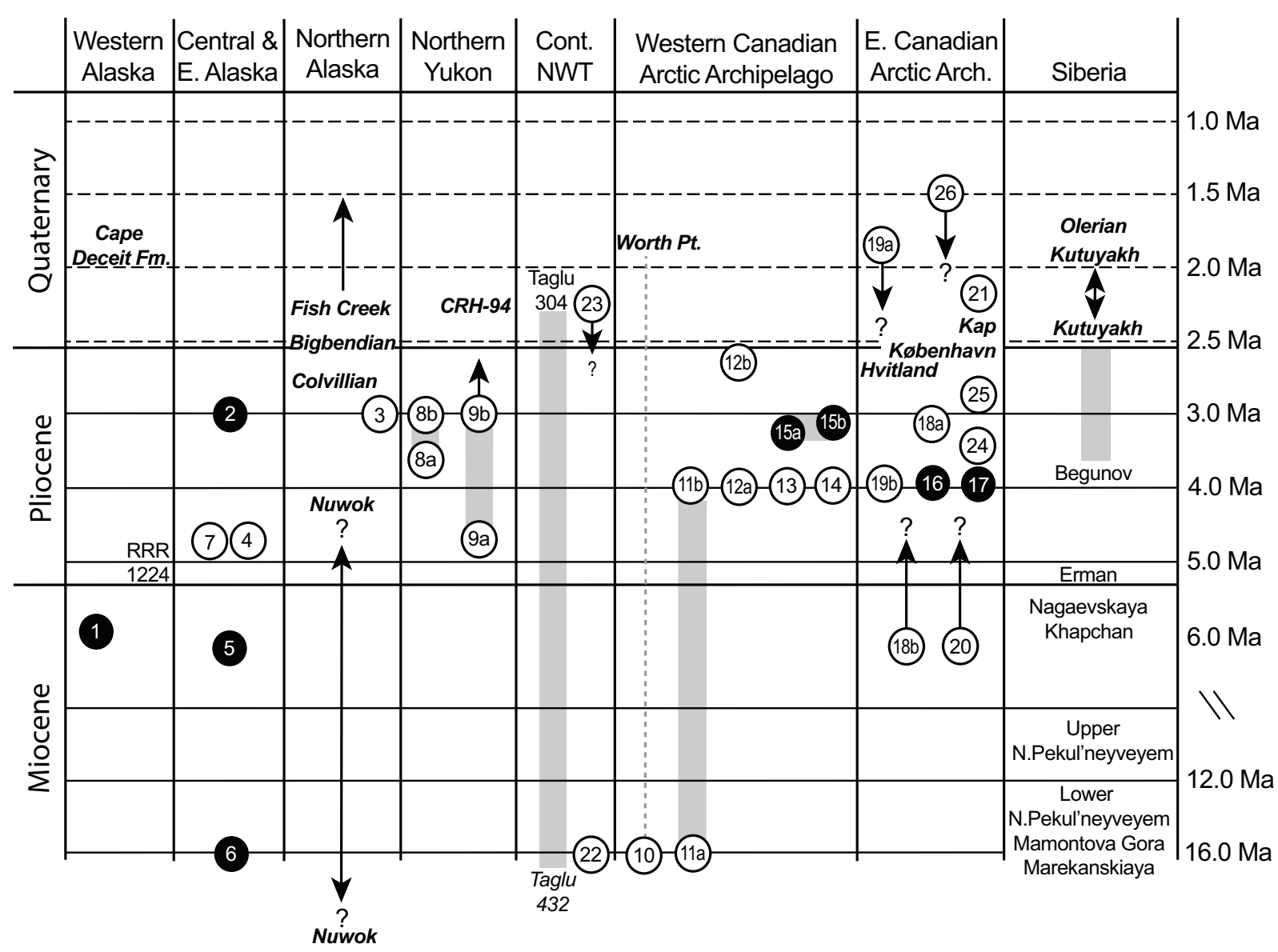

FIGURE 10. Correlation diagram. See text for details. Black circles and sites in bold face are independently dated. Note scale change in the Miocene part of the table. Double pointed arrows indicate possible age range of the site. Shaded column between certain sets indicates sites in stratigraphic superposition. Grey dotted line (10) indicates that although the flora appears mid-Miocene, the flora and surrounding sediment may have been redeposited much later. (1) Lava Camp mine, western Alaska (5.9 Ma); (2) Lost Chicken mine, east central Alaska (2.9 Ma); (3) Niguanak site, northern Alaska; (4) Cone Bluff, Porcupine River, east central Alaska; (5) Canyon Village section, Porcupine River, east central Alaska (6.4 Ma, late Miocene); (6) Upper Ramparts site, Porcupine River, east central Alaska (16 Ma); (7) Circle Gravels, east central Alaska (early Pliocene); (8a and 8b) Ch'ijee's Bluff, Unit 1 (8a) and Unit 2 (8b), northern Yukon; (9a and 9b) Bluefish Section, northern Yukon; (10) Mary Sachs gravel, southern Banks Island, NWT; (11a and 11b) Ballast Brook Formation (11a) and Beaufort Formation (11b) at Ballast Brook, northern Banks Island, NWT; (12a and 12b) Prince Patrick Island, NWT; typical Beaufort deposits from many sites on the island (12a) and Green Bay beds (12b); (13) Melville Island, NWT; Beaufort Formation; (14) Bathurst Island, Nunavut; Beaufort Formation; (15a and 15b) Meighen Island, Nunavut; deposits below (15a) and above (15b) the approximately $3 \mathrm{Ma}$ marine unit within the Beaufort Formation; (16) Beaver Pond locality, Strathcona Fiord, Ellesmere Island, Nunavut (3.9 Ma); (17) Fyles Leaf beds site near the Beaver Pond locality at Strathcona Fiord, Ellesmere Island, NWT (3.8 $\mathrm{Ma}$ ); (18a) Riediger Site, Ellesmere Island, NWT; (18b) Site within 2 km of Riediger Site, Ellesmere Island, Nunavut; (19a) Rochon Site, Vendom Fiord region, Ellesmere Island, Nunavut; (19b) Typical high terrace sediments near the Rochon site on Vendom Fiord, Ellesmere Island, Nunavut; (20) Isachsen Site near the head of Makinson Inlet, Ellesmere Island, Nunavut; (21) Capping gravels and sands at Geodetic Hills Eocene locality, Axel Heiberg Island, Nunavut; (22) West River site near Horton River upland, northern mainland, coast, NWT; (23) Plateau Cap gravels, Horton upland, northern mainland coast, NWT; (24) Remus Creek site, Fosheim Peninsula, Ellesmere Island, NWT; (25) South Bay site, Fosheim Peninsula, Ellesmere Island, Nunavut; (26) Fosheim Dome, Fosheim Peninsula, Ellesmere Island, Nunavut. 
tism, other types of fossils, or all three, we use the term 'keystone'. Figure 10 is the most recent attempt to correlate and date the sites discussed here, using keystone floras and faunas as well as the less direct inferences on relative age as detailed in the previous section. The numbered floras correspond to the numbers used throughout the text and in Appendix 1. Keystone floras and faunas are identified in the figure by solid black circles with white numerals.

In Figure 10, numbered floras shown with open circles are dated primarily by their fossil content. The figure also includes several named sites, which were included in a previous correlation diagram (Matthews and Ovenden, 1990) but are not included with the floras in Appendix 1. Of these, keystone sites are shown in bold oblique typeface. Grey areas separating some sites show that they are part of the same exposure or series of exposures in a region and are reliably known to be in correct relative position. The following comments provide justification for some of the assignments shown in Figure 10.

\section{Western Alaska}

Over the last 50 years there has been significant dispute over the age of the Cape Deceit Formation, much of which has been outlined by McDougall (1995). The formation is known to have normal palaeomagnetic polarity (Brigham-Grette and Hopkins, 1991), and this limits the possibilities. Repenning and Brouwers (1992) suggested the age of the Cape Deceit Formation as about 1.3 Ma and that it spans some $0.4 \mathrm{Ma}$. We question the latter statement because it is based on what may only be minor fluctuations of tree line during deposition of the unit rather than worldwide climatic fluctuations. Sher (1986) believed that the Cape Deceit Formation is as young as $1 \mathrm{Ma}$. In both these interpretations, the Cape Deceit Formation would have represented the Jaramillo subchron (Chron 1r.1n: 0.984-1.049 Ma, Cande and Kent, 1992). However, the formation has yielded extinct microtine rodent fossils (Guthrie and Matthews, 1971), which have been used for correlation and dating (Brigham-Grette and Hopkins, 1991; Repenning, 2003; Storer, 2003), the latter study suggesting the Cape Deceit Formation is as old as the Olduvai subchron $(\sim 1.8 \mathrm{Ma})$ due to the more primitive condition of the upper third molar in the Cape Deceit fossils compared to those of Fort Selkirk specimens, with fission-track and radiometric dates of 1.5 to $1.7 \mathrm{Ma}$ (Storer, 2003). This older age is the interpretation shown in Figure 10. For purposes of correlation with the flora, what is most important about the Cape Deceit Formation is that it has yielded a large assemblage of plants, none of them representing extinct species; even the Larix cones from one of the subsidiary units seem more closely allied to $L$. laricina than to the extinct long-bracted $L$. groenlandii type cones found in several of the floras discussed here. The temperature estimate from mutual climate range of beetles is Tmaxmean of $8.4^{\circ} \mathrm{C}$ or $3.1^{\circ} \mathrm{C}$ warmer than present, and Tmin-mean -24.8 or $4.5^{\circ} \mathrm{C}$ colder than present, (Elias and Matthews, 2002).

Sample RRR-1224 from near Cape Deceit is considered to be close to the age of Lava Camp, though slightly younger according to some of the fossils in the sparse insect fauna. Site RRR-1226, from the same area as RRR-1224, is not shown in Figure 10 because it seems now to be much younger even than the age of the Cape Deceit Formation.

The $\mathrm{K}-\mathrm{Ar}$ date on basalt at the Lava Camp mine (1 in Figure 10) shows that it is late Miocene (Hopkins et al., 1971). The age was recalibrated to $5.9 \pm 0.2 \mathrm{Ma}$ (Turner et al., 1980), making it very close to the age of the Canyon Village site in eastcentral Alaska.

\section{Central and Eastern Alaska}

The main difference in Figure 10 compared to previous diagrams (Matthews and Ovenden, 1990) is that Lost Chicken (2) is relocated to $3 \mathrm{Ma}$, Cone Bluff (4), and Circle Gravels (7) are shown in the early Pliocene and Canyon Village (5), dated by $\mathrm{Ar} /$ Ar on tephra, is placed in the late Miocene (6.4 Ma; Fouch et al., 1994; Kunk et al., 1994). The Upper Ramparts (6), though placed in the same position on the correlation chart of Matthews and Ovenden (1990), has since become a keystone site because it is radiometrically dated at about $16 \mathrm{Ma}$ and much more is now known about its flora (Fouch et al., 1994; White and Ager, 1994).

\section{Northern Alaska}

There remains considerable controversy about the age of the Carter Creek, Nuwok site. Pollen and ostracods call for an early Pliocene age (Ager, personal commun., 1990; Marincovich, personal commun., 1991; Marincovich et al., 1991; Brouwers, 1994), while a late Oligocene age is suggested by benthic foraminifera and $\mathrm{Sr}$ isotope ratios (McNeil and Miller, 1990). In Figure 10 we show the younger option, but with an arrow indicating the possibility that the site might be much older. 
Sediments representing three major transgressions have been recognized on the Alaskan north and west coasts (Kaufman, 1992; Kaufman and Brigham-Grette, 1993). Although in some cases the logic for dating these deposits is somewhat tortuous, they do represent keystone units for purposes of correlation. The position of the three transgressions as shown in Figure 10 follows Repenning and Brouwers (1992), who attempt to place the northern Alaskan transgressions in the context of world-wide events. The upward pointing arrow above the Fishcreekian reflects the opinion of McDougall (1995), who dated it to the 1.2-1.7 Ma based on the benthic foraminiferal assemblage.

Niguanak (3) has yet to be described and discussed in detail, especially the very informative pollen data (Nelson, personal commun., 1987). In Figure 10, Niguanak is shown older than previously (Matthews and Ovenden, 1990). This adjustment is made because the yet to be published pollen data strongly imply that the Niguanak is older than the Colvillian Transgression. The temperature estimate from mutual climate range of beetles is Tmaxmean of $10.6^{\circ} \mathrm{C}, 6.2^{\circ} \mathrm{C}$ warmer than present, and Tmin-mean $-25.5^{\circ} \mathrm{C}, 0.7^{\circ} \mathrm{C}$ warmer than present (Elias and Matthews, 2002).

\section{Northern Yukon}

The age of the two lower units at Ch'ijee's Bluff (Units 1,2) on the Porcupine River and two units at the Bluefish section (Units $A, B$ ) not far from Ch'ijee's bluff, remains uncertain. Bluefish Unit A (9a) is considered to be no younger than early Pliocene based on floral similarity with the biostratigraphically dated Circle Gravels (Flora 7; Ager et al., 1994). Bluefish Unit A and Circle Gravels, as well as Cone Bluff (4), have fossil macrofloras containing Aralia, Comptonia, Paliurus type, and distinctive endocarps of Prunus. None of these taxa occur in the $3 \mathrm{Ma}$ Lost Chicken flora (2), nor in the Bluefish Unit B flora (9b).

Bluefish Unit B (9b) flora is placed at an older age level than in Matthews and Ovenden (1990) chiefly because it contains well-preserved Epipremnum crassum. The LAD for E. crassum in east Central Alaska and northern Yukon is probably about $3 \mathrm{Ma}$. Epipremnum crassum has not been found at Ch'ijee's Bluff and this could have biostratigraphic implications; however, the sediments at Ch'ijee's Bluff comprise partly cemented sands (alluvium) and the authors noted that Epipremnum fossils seem usually, if not always, associated with very peaty and mostly autochthonous contexts. As a result, the lack of Epipremnum at Ch'ijee's Bluff maybe related to the depositional environment, rather than the deposit being of younger age.

A second important biostratigraphic taxon that differs between these floras is Pinus. Bluefish Unit $B(9 b)$ contains no pine macrofossils, and yet they do occur in the lower Unit A flora (9a), and in both floras at Ch'ijee's Bluff $(8 a, b)$. This may mean that the Bluefish Unit B flora (9b) is slightly younger than both Ch'ijee's Unit 1 and $2(8 a, b)$, although such negative evidence is no more or less powerful than the apparent absence of Epipremnum at Ch'ijee's Bluff.

At Lost Chicken (2), Pinus (Strobus) was found in association with Epipremnum in the section containing the Fortymile tephra (Station 91-3 in Matthews et al., 2003), but not in the adjacent section (Station 91-2) containing the Lost Chicken tephra. If the two tephra are of the same age, then this is evidence of Pinus (Strobus) in east-central Alaska as late as $3 \mathrm{Ma}$. It would then follow that Ch'ijee's Bluff Unit 1 (Flora 8a) might also be as young as $3 \mathrm{Ma}$ because it also contains needles and cones of one or more Pinus (Strobus). However, the age of the Fortymile tephra and its relationship to the Lost Chicken tephra cannot be resolved. In this case, the negative evidence is also relatively weak and will remain so until large samples have been studied or other means of dating and correlation are applied.

Although the $\mathrm{CRH}-94$ site (Figure 10) has yielded very few macrofossils, pollen analyses associated with the Little Timber tephra, found in the lower part of the exposure, imply an open coniferous forest, possibly including Abies (fir), which today is only rarely found in the forests of the northern Yukon. Recent dating of the tephra shows it to be $2.29 \pm 0.25 \mathrm{Ma}$ in age (Westgate et al., 1995) rather than 1.2 Ma shown in Matthews and Ovenden (1990).

\section{Mainland NWT}

The placement of floras in this column of Figure 10 reflects new knowledge obtained since publication of the previous diagram (Matthews and Ovenden, 1990). The arguments relating to the age of the West River flora near Horton River (Flora 22) and Plateau Cap gravels from the Horton upland (23) are discussed above. Briefly, the flora from West River has many of the taxa seen at mid-Miocene sites, whereas the flora of Plateau Cap gravels is fully modern except for the presence of an extinct larch, similar to the one first 
found in the Kap København Formation of northern Greenland, Larix groenlandii (Bennike, 1990).

\section{Western Canadian Arctic Archipelago}

The western Canadian Arctic Archipelago refers here to all of those islands within the archipelago west of Axel Heiberg Island including Banks, Prince Patrick, Melville, Bathurst, and Meighen Islands. Most well-studied of these islands is Banks Island, which includes deposits of Pleistocene, Pliocene, and Miocene age. Age estimation for Banks Island deposits shown in Figure 10 for Mary Sachs gravel (Flora 10), Ballast Brook Formation (11a), and Beaufort Formation (11b) are given elsewhere (Fyles et al., 1994) and above. A slight change from Matthews and Ovenden (1990) is the placement of the Pleistocene Worth Point deposits, because recent geomagnetic results suggest that the organic deposits at the type locality fall within the Olduvai subchron (Vincent, personal commun., 1993; Duk-Rodkin et al., 2004). The age of the Worth Point Formation is an extremely important datum because its flora, unlike most of those discussed here, is entirely modern.

In Figure 10, the placement of the three Beaufort Formation floras, Prince Patrick Island (12a), Melville Island (13), and Bathurst Island (14) at 4.0 $\mathrm{Ma}$ (the same age as the Beaufort Formation at Ballast Brook; Flora 11b), is somewhat arbitrary and potentially misleading. The most that can be said is that the four floras and faunas are no younger than the upper Meighen Island flora/fauna and are probably no older than the base of the Pliocene. The two Meighen Island floras (15a and $15 \mathrm{~b})$ are in stratigraphic superposition. The age of these floras was argued based on multiple lines of evidence from within the marine incursion layer that separates them, with no evidence for an extended hiatus in deposition, as argued in Fyles et al. (1991). A re-evaluation of this age is currently in review (Barendregt, personal commun. 2020).

The position of the Green Bay beds of Prince Patrick Island (12b) in Figure 10 is based on the stratigraphy at the site and the occurrence of several extinct species. The former evidence suggests that it is younger than typical Beaufort Formation deposits and the fossils suggest that it is no younger than latest Pliocene. Clearly this very rich deposit, with its excellently preserved fossils, requires further detailed study.

\section{Eastern Canadian Arctic Archipelago and Greenland}

In spite of the burgeoning number of sites with macrofossils from Ellesmere Island, only three are independently dated (i.e., using radiometric geochronology, rather than only biostratigraphy). The first, the Hvitland site (Fyles et al., 1998) does not constitute a keystone site for correlation of terrestrial sites, because the sediments at Hvitland are marine and contain very few plant or insect fossils. It may be significant, though, that one of the dominant plant macrofossils from Hvitland is the type of Dryas seen at the Kap København site of only slightly younger age.

The Beaver Pond flora (16) as dated from the main site (3.9+1.5/ $-0.5 \mathrm{Ma}$; Fletcher et al., 2019b), is a keystone site of great diversity and helps link the Ellesmere Island sites to others around the Arctic. It is one of the few that has yielded biostratigraphically significant mammalian fossils, with closest affinity to members of early Pliocene midcontinent local faunas in Eurasia and to a lesser extent in North America (Tedford and Harington, 2003; Wang et al., 2017). An early Pliocene age is also supported by the plant macrofossil record, specifically the presence of Paliurus-type fruits. This taxon, whatever its true identity, is missing from all of the Meighen Island Beaufort Formation samples, supporting the evidence that the Beaver Pond locality deposits and associated sections are older than 3.2 Ma.

Sediments from the Fyles Leaf Beds section (Flora 17; 3.8+1.0/ -0.7 Ma; Rybczynski et al., 2013), about $10 \mathrm{~km}$ from the Beaver Pond locality, also contain Paliurus and have been dated to approximately the same age as Beaver Pond. The combination of the fossils preserved in these two very different depositional environments, but approximately coevally, may prove valuable to our palaeoenvironmental understanding of this region in particular. This site is now recognised as a keystone site given the increased information now available at this site and its absolute dating.

The Rochon flora (19a) is almost certainly younger than most of the others from Ellesmere Island; however, its insect fauna shows that it could be as old as the Kap København Formation. The fact that spruce was growing on southern Ellesmere Island during deposition of the Rochon sediments also suggests it is as old or older than early Pleistocene.

Of the several high terrace sites on the Fosheim Peninsula that are discussed in Matthews and Fyles (2000) only three: Remus Creek (24), 
South Bay (25), and a collection of sites from Fosheim Dome (26), are shown in Figure 10. Presence of fossils of a distinctive extinct beetle shows that the South Bay site is Pliocene in age. The diverse assemblage of plant macrofossils suggests a similar age for the Remus Creek site; however, it may not be as old as the Beaver Pond flora because its rich flora does not contain Paliurus. The Fosheim Dome assemblages clearly indicate that the deposits are younger, but by how much is unknown. They may even represent a Quaternary interglacial.

Two of the Ellesmere Island floras, Isachsen (20) and unnamed site (18b) paired here with the main Riediger site (18a), are tentatively referred to late Miocene. This is because they contain plant taxa that have been found in Alaska dated to late Miocene (e.g., 'Cyperaceae type A', see Appendix 1). As indicated earlier there are other reasons why assemblages from these two sites (18b and 20) appear different from the rest. The most likely explanation for such differences is that the sites are older than the others, but we cannot rule out the possibility that they differ because they represent a significantly warmer climate as a result of being younger than the other sites. For example, an alternative hypothesis to their being of Miocene age would be that the two sites could be as young as the latter part of the early Pliocene.

Only a single flora from Axel Heiberg Island is included in this report (21). The site is located in the gravels and sands capping the Eocene-aged deposits of the Geodetic Hills. Based on the vascular plant and bryophyte fossils from the autochthonous peat, especially the presence of the extinct Aracites globosus, it is concluded that the deposits are similar in age to those of Kap København of northern Greenland.

\section{Siberia}

East Siberia and northwestern North America were united by a land bridge through most of the Cenozoic, up to the late Miocene (Marincovich and Gladenkov, 2001; Gladenkov et al., 2002). This means that Neogene floras on either side of Bering Strait should be somewhat similar in taxonomic content. One of the best studied areas for the latest Neogene in Siberia is the Kolyma Lowland.

According to Sher et al. (1979) and Sher (personal commun., 1992) the Begunov Suite (Figure 1) at the Krestovka section is more likely to be early Pliocene than mid-Pliocene (late Pliocene in current usage) in age; a position accepted by Nikitin (2007). Its flora is thought to represent an impoverished version of the late Miocene Khap- chan flora from farther west. One of us (JVM) has examined samples thought to come from the upper part of the Begunov Suite at Krestovka, and even though they contain a few taxa not previously reported (e.g., Aracites globosa, a small form of Epipremnum crassum and a peculiar Sparganium similar to one found in Unit 2 at Ch'ijee's Bluff), the Begunov assemblages are remarkably impoverished compared to the Khapchan flora (Table 3). Taphonomic factors may be responsible, but the Begunov flora is also much less diverse than the late Miocene Canyon Village flora. Even the $3 \mathrm{Ma}$ Meighen Island flora is much richer. If floral diversity is an indication of age in the Arctic Neogene, it could only be concluded that Begunov Suite is younger than early Pliocene.

The Kutuyakh beds in the Kolyma lowland straddle the Gauss/Matuyama boundary (Sher et al., 1979; Repenning and Brouwers, 1992). They mark an important environmental threshold, the first appearance of permafrost in northeastern Siberia.

Placement of the other key Russian floras in Figure 10 is based on diagrams in Baranova and Biske (1979); Biske (1979); Gladenkov (1979); Biske (1975); Biske et al. (1972), Nikitin (2006), and Nikitin (2007). Because of its content of numerous seeds and fruits, foliar remains and associated pollen evidence, the Mamontova Gora (or Mammoth Mountain) flora (Dorofeev, 1969; Baranova et al., 1976), on the Aldan River (Figure 1 ), is one of the most valuable sites for comparison with other eastern Siberian and Arctic North American Neogene floras. However, the Mamontova Gora flora apparently is no more reliably dated than some of the North American floras discussed here, i.e., it is not a keystone site. It is placed in either the mid-Miocene (18 Ma; Baranova et al., 1976) or the second warm interval of the Miocene (13 Ma; Zubakov and Borzenkova, 1990), while Nikitin (2007) places it in the Langhian ( 14-16 Ma).

It would be remiss to write a comparison of Arctic and Subarctic floras from the Neogene and early Pleistocene without mentioning Lake El'gygytgyn (Melles et al., 2012; Brigham-Grette et al., 2013; Andreev et al., 2014; Andreev et al., 2016, 2020). Although the Lake El'gygytgyn palynofloral record is unparalleled, it is difficult to compare these records to taxa lists defined by macrofloral deposits, and doubly so given the disjunct between the palynoflora and macrofloras, discussed further below. Thus, comparison should 
TABLE 3. Comparison of late Miocene and early Pliocene Florules from Eastern Siberia, Alaska and northern Canada.

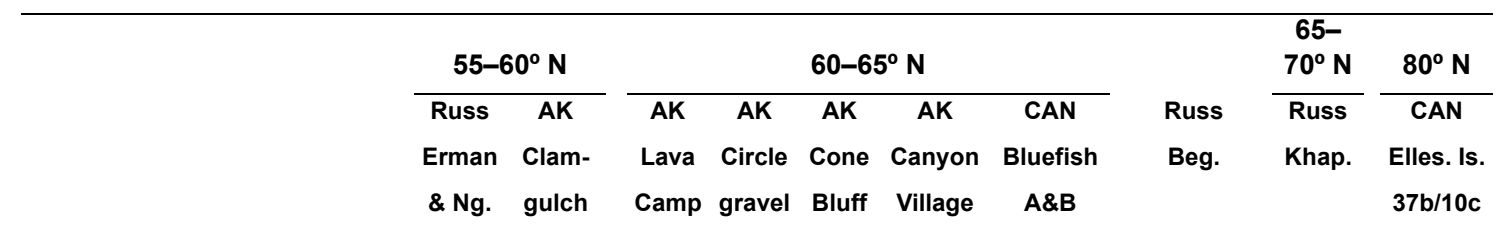

\section{Tracheophyta}

Lycopodiophytina

Selaginellaceae

Selaginella

Polypodiophytina

Equisetaceae

Equisetum

Osmundaceae

Osmunda

Salviniaceae

Azolla

Salvina

Spermatophytina

Pinopsida

Pinaceae

Abies

Larix

Picea

Pinus

Pinus (Pinus) '2-needle undiff.' +

Pinus (Pinus) '3-needle undiff.'

Pinus (Strobus) sect.

Quinquefoliae '5-needle undiff.'

Pseudotsuga sp.

Tsuga

Cupressaceae

Glyptostrobus

Juniperus

Thuja

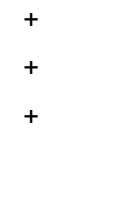

$\begin{array}{llll} & & + \\ & + & + & + \\ p & + & + & + \\ & & & \end{array}$

Magnoliopsida

Typhaceae

Sparganium

Typha

Potamogetonaceae

Potamogeton

Hydrocharitaceae

Najas

Alismataceae

Caldesia

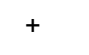

Damasonium

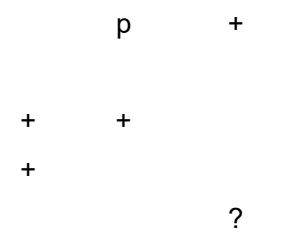


FLETCHER ET AL.: ARCTIC MACROFLORA

TABLE 3 (continued).

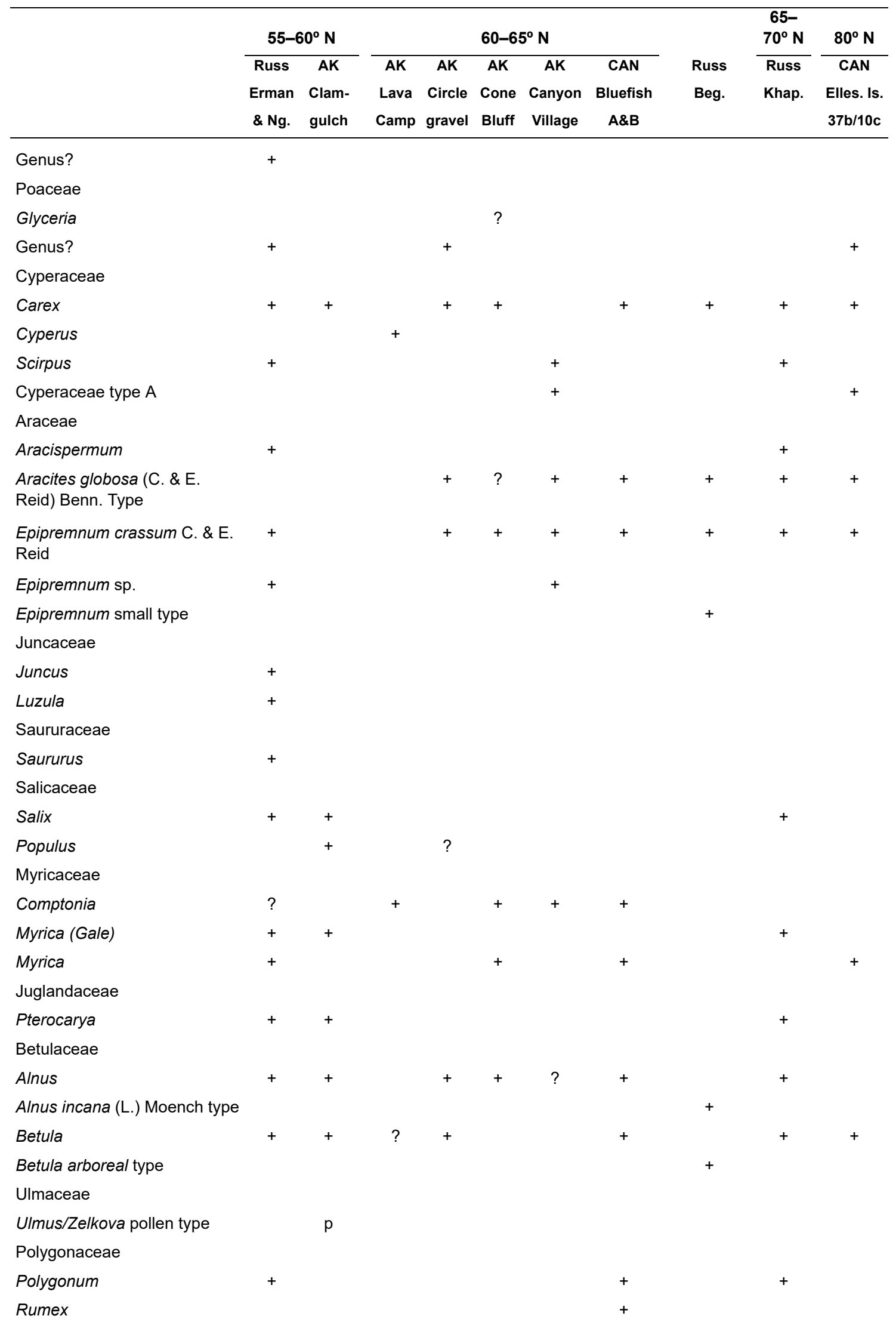


TABLE 3 (continued).

\begin{tabular}{|c|c|c|c|c|c|c|c|c|c|c|}
\hline & \multirow{2}{*}{\multicolumn{2}{|c|}{$55-60^{\circ} \mathrm{N}$}} & \multirow{2}{*}{\multicolumn{5}{|c|}{$60-65^{\circ} \mathrm{N}$}} & \multicolumn{3}{|c|}{$65-$} \\
\hline & & & & & & & & \multirow[b]{2}{*}{$\begin{array}{l}\text { Russ } \\
\text { Beg. }\end{array}$} & \multirow{2}{*}{$\begin{array}{l}70^{\circ} \mathrm{N} \\
\text { Russ } \\
\text { Khap. }\end{array}$} & \multirow{2}{*}{$\begin{array}{c}80^{\circ} \mathrm{N} \\
\text { CAN } \\
\text { Elles. Is. } \\
37 \mathrm{~b} / 10 \mathrm{c}\end{array}$} \\
\hline & $\begin{array}{l}\text { Russ } \\
\text { Erman } \\
\& \mathrm{Ng} .\end{array}$ & $\begin{array}{c}\text { AK } \\
\text { Clam- } \\
\text { gulch }\end{array}$ & $\begin{array}{c}\text { AK } \\
\text { Lava } \\
\text { Camp }\end{array}$ & $\begin{array}{c}\text { AK } \\
\text { Circle } \\
\text { gravel }\end{array}$ & $\begin{array}{c}\text { AK } \\
\text { Cone } \\
\text { Bluff }\end{array}$ & $\begin{array}{c}\text { AK } \\
\text { Canyon } \\
\text { Village }\end{array}$ & $\begin{array}{c}\text { CAN } \\
\text { Bluefish } \\
\text { A\&B }\end{array}$ & & & \\
\hline \multicolumn{11}{|l|}{ Amaranthaceae } \\
\hline Amaranthus & + & & & & & & & & & \\
\hline \multicolumn{11}{|l|}{ Caryophyllaceae } \\
\hline Genus? & & & & + & & & & & & \\
\hline \multicolumn{11}{|l|}{ Cabombaceae } \\
\hline Brasenia & & & & & & + & + & & + & \\
\hline \multicolumn{11}{|l|}{ Nymphaeaceae } \\
\hline Nuphar & + & & & & & + & + & & + & \\
\hline Nymphaea & & & & & & + & & & & + \\
\hline \multicolumn{11}{|l|}{ Ceratophyllaceae } \\
\hline Ceratophyllum & & & & & & & + & & & \\
\hline Ceratophyllum submersum L. & & & & & & & & + & & \\
\hline \multicolumn{11}{|l|}{ Ranunculaceae } \\
\hline Ranunculus (Halerpestes) & + & & & & & & & & & \\
\hline Ranunculus & + & & & + & & & + & + & + & \\
\hline \multicolumn{11}{|l|}{ Saxifragaceae } \\
\hline Chrysoplenum & & & & & & & + & & & \\
\hline \multicolumn{11}{|l|}{ Rosaceae } \\
\hline Comarum palustre L. type & + & & & + & & & + & & + & + \\
\hline Dryas & & & & + & & & + & + & & \\
\hline Malus & & + & & & & & & & & \\
\hline Potentilla & + & & & + & + & & & & + & \\
\hline Prunus padus L. type & + & & & + & & & + & & & \\
\hline Prunus & & + & & + & & + & + & & + & \\
\hline Rosa & & & & & & & & & & + \\
\hline Rubus & + & + & & + & & & & + & + & + \\
\hline Sorbus & & + & & & & & & & & + \\
\hline Spiraea & & + & & & & & & & & \\
\hline \multicolumn{11}{|l|}{ Rhamnaceae } \\
\hline Paliurus cf. & & & + & + & + & & + & & + & + \\
\hline \multicolumn{11}{|l|}{ Hypericaceae } \\
\hline Hypericum & & & & + & & + & & & & \\
\hline \multicolumn{11}{|l|}{ Elatinaceae } \\
\hline Elatine & + & & & & & & & & & \\
\hline \multicolumn{11}{|l|}{ Violaceae } \\
\hline Viola & + & & & + & & & & & + & \\
\hline
\end{tabular}


TABLE 3 (continued).

\begin{tabular}{|c|c|c|c|c|c|c|c|c|c|c|}
\hline & \multirow{2}{*}{\multicolumn{2}{|c|}{$55-60^{\circ} \mathrm{N}$}} & \multirow{2}{*}{\multicolumn{5}{|c|}{$60-65^{\circ} \mathrm{N}$}} & \multirow[b]{3}{*}{$\begin{array}{l}\text { Russ } \\
\text { Beg. }\end{array}$} & \multirow{3}{*}{$\begin{array}{c}\begin{array}{c}65- \\
70^{\circ} \mathrm{N}\end{array} \\
\text { Russ } \\
\text { Khap. }\end{array}$} & \multirow{3}{*}{$\begin{array}{c}80^{\circ} \mathrm{N} \\
\text { CAN } \\
\text { Elles. Is. } \\
37 \mathrm{~b} / 10 \mathrm{c}\end{array}$} \\
\hline & & & & & & & & & & \\
\hline & $\begin{array}{l}\text { Russ } \\
\text { Erman } \\
\& \mathrm{Ng} .\end{array}$ & $\begin{array}{c}\text { AK } \\
\text { Clam- } \\
\text { gulch }\end{array}$ & $\begin{array}{c}\text { AK } \\
\text { Lava } \\
\text { Camp }\end{array}$ & $\begin{array}{c}\text { AK } \\
\text { Circle } \\
\text { gravel }\end{array}$ & $\begin{array}{c}\text { AK } \\
\text { Cone } \\
\text { Bluff }\end{array}$ & $\begin{array}{c}\text { AK } \\
\text { Canyon } \\
\text { Village }\end{array}$ & $\begin{array}{c}\text { CAN } \\
\text { Bluefish } \\
\text { A\&B }\end{array}$ & & & \\
\hline \multicolumn{11}{|l|}{ Lythraceae } \\
\hline $\begin{array}{l}\text { Decodon globosus (E.M. Reid) } \\
\text { Nikitin type }\end{array}$ & + & & & + & + & + & & & + & + \\
\hline $\begin{array}{l}\text { Decodon gibbosus (E.M. Reid) } \\
\text { E.M. Reid in Nikitin type }\end{array}$ & + & & & & & & & & & \\
\hline Microdiptera/Mneme type & & & & & & + & & & + & \\
\hline \multicolumn{11}{|l|}{ Lythraceae } \\
\hline Trapa & & + & & & & + & & & & \\
\hline \multicolumn{11}{|l|}{ Plantaginaceae } \\
\hline Hippuris & + & & + & + & & + & + & + & + & \\
\hline \multicolumn{11}{|l|}{ Haloragaceae } \\
\hline Myriophyllum & & & & & & & + & & + & \\
\hline \multicolumn{11}{|l|}{ Araliaceae } \\
\hline Aralia & + & & & + & + & & + & & & \\
\hline \multicolumn{11}{|l|}{ Eleutherococcus } \\
\hline \multicolumn{11}{|l|}{ Cornaceae } \\
\hline Cornus & + & & + & & + & & & + & + & \\
\hline \multicolumn{11}{|l|}{ Ericaceae } \\
\hline Andromeda & + & & & & + & + & & & + & + \\
\hline Chamaedaphne & + & & & + & & & + & & & + \\
\hline Oxycoccus & & & & + & & & & & & \\
\hline Vaccinium & & + & + & & + & + & & & & \\
\hline Genus? & + & & & + & + & & & & & \\
\hline \multicolumn{11}{|l|}{ Aquifoliaceae } \\
\hline Ilex & & & & & & $?$ & & & & \\
\hline \multicolumn{11}{|l|}{ Primulaceae } \\
\hline Lysimachia & + & & & & & & & & & \\
\hline \multicolumn{11}{|l|}{ Gentianaceae } \\
\hline Menyanthes & + & & + & & + & + & + & & + & + \\
\hline Menyanthes trifoliata L. & & & & & & & & + & & \\
\hline Menyanthes small form & & & & & & & & + & & \\
\hline Nymphoides & & & & & & & & & & + \\
\hline \multicolumn{11}{|l|}{ Lamiaceae } \\
\hline Lycopus & + & & & & & & & & & \\
\hline \multicolumn{11}{|l|}{ Solanaceae } \\
\hline Solanum/Physalis type & + & & & & & & & & & \\
\hline \multicolumn{11}{|l|}{ Orobanchaceae } \\
\hline Boschniakia & & & & & & & & & & + \\
\hline Pedicularis & + & & & & & & & & & \\
\hline
\end{tabular}


TABLE 3 (continued).

\begin{tabular}{|c|c|c|c|c|c|c|c|c|c|c|}
\hline & \multirow{2}{*}{\multicolumn{2}{|c|}{$55-60^{\circ} \mathrm{N}$}} & \multirow{2}{*}{\multicolumn{5}{|c|}{$60-65^{\circ} \mathrm{N}$}} & \multicolumn{3}{|c|}{$65-$} \\
\hline & & & & & & & & & $70^{\circ} \mathrm{N}$ & $80^{\circ} \mathrm{N}$ \\
\hline & $\begin{array}{c}\text { Russ } \\
\text { Erman } \\
\& \mathrm{Ng} .\end{array}$ & $\begin{array}{c}\text { AK } \\
\text { Clam- } \\
\text { gulch }\end{array}$ & $\begin{array}{c}\text { AK } \\
\text { Lava } \\
\text { Camp }\end{array}$ & $\begin{array}{c}\text { AK } \\
\text { Circle } \\
\text { gravel }\end{array}$ & $\begin{array}{c}\text { AK } \\
\text { Cone } \\
\text { Bluff }\end{array}$ & $\begin{array}{c}\text { AK } \\
\text { Canyon } \\
\text { Village }\end{array}$ & $\begin{array}{c}\text { CAN } \\
\text { Bluefish } \\
\text { A\&B }\end{array}$ & $\begin{array}{l}\text { Russ } \\
\text { Beg. }\end{array}$ & $\begin{array}{l}\text { Russ } \\
\text { Khap. }\end{array}$ & $\begin{array}{c}\text { CAN } \\
\text { Elles. Is. } \\
37 b / 10 c\end{array}$ \\
\hline Adoxaceae & & & & & & & & & & \\
\hline Sambucus & + & & & + & + & & + & + & + & \\
\hline Caprifoliaceae & & & & & & & & & & \\
\hline Diervilla & & $\mathrm{p}$ & & & & & & & & \\
\hline Symphoricarpos & & & + & & & & & & & \\
\hline Valeriana cf. & & & & + & & & & & & \\
\hline Weigela & & & & + & & & & & & \\
\hline
\end{tabular}

"Russ Erman \& Ng,": Combined floras from the Erman Suite, Mio-Pliocene of Kamchatka and the Nagaevskaya beds of the Magadan region (Biske et al., 1972).

"AK Clamgulchian": Various Clamgulchian age floras; Cook Inlet region of Alaska (Wolfe et al., 1966).

"AK Lava Camp": Lava Camp site (Flora 1); Seward Peninsula, Alaska (Hopkins et al., 1971; Matthews and Ovenden, 1990).

"AK Circle gravel": high level gravels of the Yukon near Circle, Alaska (Flora 7); see Ager et al., 1994.

"AK Cone Bluff": Porcupine R., Alaska (Flora 4) (Matthews and Ovenden, 1990).

"AK Canyon Village": Localities 90-7 and 90-8 near Canyon Village on the Porcupine River, Alaska (Flora 5).

"CAN Bluefish A\&B": Bluefish section, units A and B (Matthews and Ovenden, 1990), combined flora, northern Yukon (Flora 9a and 9b).

"Russ Beg." Begunov Suite, Krestovka Section, Kolyma Lowland; modified from Sher et al., 1979 and unpublished information held by the author.

"Russ Khap": Combination from several florules at the Khapchan-Yana section illustrated in (Dorofeev, 1972).

"CAN Elles. Is. 37b/10c": Isachsen (Flora 20), Ellesmere Island, Canadian Northwest Territories.

await a palynologically focused treatment of the floras of the Neogene and early-Pleistocene Arctic.

\section{INTERREGIONAL FLORAL COMPARISONS}

One of the objectives of this paper is to place on record the composition of North American Arctic macrofloras so they can be used for interregional comparisons. Tables 2, 3, and 4 represent the first attempt to compare New and Old World Neogene macrofloras. Admittedly, they are incomplete and fraught with problems. First the reader must realize that the authors have not examined fossils from any of the Old World floras listed in the tables. For this reason, we limit comparisons to the generic level. Second, for some of the taxa in Old World floras we use North American synonyms to facilitate comparisons, causing the lists to appear slightly different from their form in the primary references. Third, the floras are grouped according to their present latitude in order that latitudinal differences can be recognized and accounted for.

\section{Late Pliocene Floras}

Table 2 compares vascular floras from several late Pliocene sites in the Arctic. The comparison is limited because the florules are not all of the same age. Furthermore, because the Pliocene was a time when major climatic oscillations occurred, floras of approximately the same age may contain markedly different suites of fossils due to different climatic constraints. In other words, for the Pliocene one should be wary of dating floras strictly on the basis of their floral diversity and content. In particular, the assumption that younger flora will always be less diverse than older ones may be incorrect. For example, at times diversity may simply reflect the volume of material collected for the original analyses, a quirk of the taphonomy of the site, or the shallow amplitude cycles of climate that, while not as dramatic as the glacial/interglacial cycles of the Pleistocene, likely had strong impacts at these northern limits of many flora.

\section{Late Miocene - Early Pliocene Floras}

Table 3 compares Mio/Pliocene floras from several sites in Siberia with some of those discussed here.

The Nagaevskaya beds of the Magadan region and the Erman Suite on the western side of the Kamchatka Peninsula are at approximately the same latitude as the Cook Inlet Clamgulchian localities. Similarly, Lava Camp in western Alaska 
TABLE 4. Comparison of mid-Miocene and early late Miocene Florules from Eastern Siberia, Alaska and northern Canada.

\begin{tabular}{|c|c|c|c|c|c|c|c|c|c|}
\hline \multirow{2}{*}{ Taxa* } & \multicolumn{3}{|c|}{$55-60^{\circ} \mathrm{N}$} & \multicolumn{4}{|c|}{$60-65^{\circ} \mathrm{N}$} & \multicolumn{2}{|c|}{$65-70^{\circ} \mathrm{N}$} \\
\hline & $\begin{array}{l}\text { Russia } \\
\text { Mag. }\end{array}$ & $\begin{array}{c}\text { AK } \\
\text { Homerian }\end{array}$ & $\begin{array}{c}\text { AK } \\
\text { Seldovian }\end{array}$ & $\begin{array}{c}\text { Russia } \\
\text { Anadry } \\
\text { River }\end{array}$ & $\begin{array}{l}\text { Russia } \\
\text { Mam. } \\
\text { Gora }\end{array}$ & $\begin{array}{c}\text { AK } \\
\text { Porc. R. } \\
90-1\end{array}$ & $\begin{array}{l}\text { Can. } \\
\text { West R. } \\
\text { NWT }\end{array}$ & $\begin{array}{l}\text { Can. } \\
\text { Mary } \\
\text { Sachs }\end{array}$ & $\begin{array}{c}\text { Can } \\
\text { Ballast } \\
\text { Brk. Fm. }\end{array}$ \\
\hline \multicolumn{10}{|l|}{ Tracheophyta } \\
\hline \multicolumn{10}{|l|}{ Lycopodiophytina } \\
\hline \multicolumn{10}{|l|}{ Selaginellaceae } \\
\hline Selaginella & & $p$ & $p$ & + & + & & + & & \\
\hline \multicolumn{10}{|l|}{ Polypodiophytina } \\
\hline \multicolumn{10}{|l|}{ Osmundaceae } \\
\hline Osmunda & & + & $p$ & & & & & & \\
\hline \multicolumn{10}{|l|}{ Aspidiaceae } \\
\hline Dryopteris & & & + & & & & & & \\
\hline Onoclea & & + & + & & & & & & \\
\hline \multicolumn{10}{|l|}{ Salviniaceae } \\
\hline Azolla & & & & & + & & & & + \\
\hline Salvina & & & & & + & & & & $?$ \\
\hline \multicolumn{10}{|l|}{ Spermatophytina } \\
\hline \multicolumn{10}{|l|}{ Ginkgoopsida } \\
\hline \multicolumn{10}{|l|}{ Ginkoaceae } \\
\hline Ginkgo & & & + & & & & & & \\
\hline \multicolumn{10}{|l|}{ Pinopsida } \\
\hline \multicolumn{10}{|l|}{ Pinaceae } \\
\hline Abies & & + & & + & + & + & + & + & + \\
\hline Cedrus & & & $\mathrm{p}$ & & & & & & \\
\hline Larix & + & + & & + & + & & + & + & + \\
\hline Larix/Pseudotsuga pollen & & & $p$ & & & & & & \\
\hline Picea & + & + & $p$ & + & + & & + & + & + \\
\hline Pinus & + & + & $p$ & + & & & & & \\
\hline $\begin{array}{l}\text { Pinus (Pinus) '2-needle } \\
\text { undiff.' }\end{array}$ & & & & + & + & & & + & + \\
\hline $\begin{array}{l}\text { Pinus (Pinus) '3-needle } \\
\text { undiff.' }\end{array}$ & & & & + & + & & & & + \\
\hline $\begin{array}{l}\text { Pinus (Strobus) sect. } \\
\text { Quinquefoliae '5-needle } \\
\text { undiff.' }\end{array}$ & & + & & + & + & & + & + & + \\
\hline Pseudolarix & & & + & & & & & & \\
\hline Pseudotsuga & & & & + & & & & & + \\
\hline Tsuga & & $p$ & $p$ & + & & & + & + & + \\
\hline \multicolumn{10}{|l|}{ Cupressaceae } \\
\hline Glyptostrobus & + & + & + & + & & + & + & + & + \\
\hline Juniperus & & & & & & & & & $?$ \\
\hline Metasequoia & + & + & + & + & & + & + & + & + \\
\hline Sequoia & $?$ & & + & & & & & & \\
\hline Taxodium & & & & & & & & + & + \\
\hline Thuja & & & & & & & & + & + \\
\hline
\end{tabular}


TABLE 4 (continued).

\begin{tabular}{|c|c|c|c|c|c|c|c|c|c|}
\hline \multirow[b]{2}{*}{ Taxa* $^{*}$} & \multicolumn{3}{|c|}{$55-60^{\circ} \mathrm{N}$} & \multicolumn{4}{|c|}{$60-65^{\circ} \mathrm{N}$} & \multicolumn{2}{|c|}{$65-70^{\circ} \mathrm{N}$} \\
\hline & $\begin{array}{l}\text { Russia } \\
\text { Mag. }\end{array}$ & $\begin{array}{c}\text { AK } \\
\text { Homerian }\end{array}$ & $\begin{array}{c}\text { AK } \\
\text { Seldovian }\end{array}$ & $\begin{array}{l}\text { Russia } \\
\text { Anadry } \\
\text { River }\end{array}$ & $\begin{array}{c}\text { Russia } \\
\text { Mam. } \\
\text { Gora }\end{array}$ & $\begin{array}{c}\text { AK } \\
\text { Porc. R. } \\
90-1\end{array}$ & $\begin{array}{c}\text { Can. } \\
\text { West R. } \\
\text { NWT }\end{array}$ & $\begin{array}{l}\text { Can. } \\
\text { Mary } \\
\text { Sachs }\end{array}$ & $\begin{array}{c}\text { Can } \\
\text { Ballast } \\
\text { Brk. Fm. }\end{array}$ \\
\hline Genus? & + & $\mathrm{p}$ & & + & & & & & \\
\hline \multicolumn{10}{|l|}{ Magnoliopsida } \\
\hline \multicolumn{10}{|l|}{ Typhaceae } \\
\hline Sparganium & & & & + & + & & + & + & + \\
\hline Typha & + & + & $p$ & + & + & & & & \\
\hline \multicolumn{10}{|l|}{ Potamogetonaceae } \\
\hline Potamogeton & + & & + & + & + & & + & + & + \\
\hline \multicolumn{10}{|l|}{ Hydrocharitaceae } \\
\hline Najas & & & & & & & & & $?$ \\
\hline \multicolumn{10}{|l|}{ Alismataceae } \\
\hline Alisma & + & & + & & & & & & \\
\hline Caldesia & & & & & + & & & & \\
\hline Damasonium & & & & + & + & & cf. & & cf. \\
\hline Sagisma & & & & & & & & + & \\
\hline Genus? & & & & + & + & & & & \\
\hline \multicolumn{10}{|l|}{ Poaceae } \\
\hline Genus? & & & & + & + & & + & & + \\
\hline \multicolumn{10}{|l|}{ Cyperaceae } \\
\hline Carex & + & & & + & + & + & + & + & + \\
\hline Cladium & & & & & & & & & + \\
\hline Fimbristylis & & & & + & & & & & \\
\hline Dulichium & & & & + & + & & $?$ & + & $?$ \\
\hline Eriophorum & & & & + & & & & & \\
\hline Rhynchospora & & & & & & & & & + \\
\hline Scirpus & + & & & + & + & & & & $?$ \\
\hline \multicolumn{10}{|l|}{ Araceae } \\
\hline Aracispermum & + & & & + & & & & & $?$ \\
\hline $\begin{array}{l}\text { Aracites globosa (C. \& E. } \\
\text { Reid) Benn. type }\end{array}$ & + & & & + & + & + & + & & + \\
\hline $\begin{array}{l}\text { Epipremnum crassum C. } \\
\text { \& E. Reid }\end{array}$ & + & & & + & + & + & & + & + \\
\hline $\begin{array}{l}\text { Epipremnum crassum } \\
\text { small }\end{array}$ & & & & & & & & & + \\
\hline $\begin{array}{l}\text { Epipremnum cristatum } \\
\text { P.A. Nikitin in P.I. Dorof. } \\
\text { type }\end{array}$ & & & & cf. & & & & & \\
\hline \multicolumn{10}{|l|}{ Zingiberaceae } \\
\hline $\begin{array}{l}\text { Spirematospermum } \\
\text { wetzleri (Heer) M. } \\
\text { Chandler ex Kirchheim. }\end{array}$ & & & & & + & & & & \\
\hline
\end{tabular}


FLETCHER ET AL.: ARCTIC MACROFLORA

TABLE 4 (continued).

\begin{tabular}{|c|c|c|c|c|c|c|c|c|c|}
\hline \multirow[b]{2}{*}{ Taxa* $^{*}$} & \multicolumn{3}{|c|}{$55-60^{\circ} \mathrm{N}$} & \multicolumn{4}{|c|}{$60-65^{\circ} \mathrm{N}$} & \multicolumn{2}{|c|}{$65-70^{\circ} \mathrm{N}$} \\
\hline & $\begin{array}{c}\text { Russia } \\
\text { Mag. }\end{array}$ & $\begin{array}{c}\text { AK } \\
\text { Homerian }\end{array}$ & $\begin{array}{c}\text { AK } \\
\text { Seldovian }\end{array}$ & $\begin{array}{c}\text { Russia } \\
\text { Anadry } \\
\text { River }\end{array}$ & $\begin{array}{c}\text { Russia } \\
\text { Mam. } \\
\text { Gora }\end{array}$ & $\begin{array}{c}\text { AK } \\
\text { Porc. R. } \\
90-1\end{array}$ & $\begin{array}{c}\text { Can. } \\
\text { West R. } \\
\text { NWT }\end{array}$ & $\begin{array}{c}\text { Can. } \\
\text { Mary } \\
\text { Sachs }\end{array}$ & $\begin{array}{c}\text { Can } \\
\text { Ballast } \\
\text { Brk. Fm. }\end{array}$ \\
\hline \multicolumn{10}{|l|}{ Saururaceae } \\
\hline Saururus & & & & + & + & & & & + \\
\hline \multicolumn{10}{|l|}{ Salicaceae } \\
\hline Salix & & + & + & + & & & & & + \\
\hline Populus & + & + & + & & & & & & \\
\hline \multicolumn{10}{|l|}{ Myricaceae } \\
\hline Comptonia & & & + & + & + & + & + & + & + \\
\hline Myrica (Gale) type & & + & & & + & & & & \\
\hline Myrica & & + & & & & & + & + & + \\
\hline \multicolumn{10}{|l|}{ Juglandaceae } \\
\hline Carya & & $?$ & + & & & & & & \\
\hline Cyclocarya & & & + & & & & & & \\
\hline Juglans & & & + & + & + & & & + & \\
\hline Pterocarya & + & + & + & + & & & & & \\
\hline Pterocarya/Cyclocarya & & & + & & & & & & \\
\hline \multicolumn{10}{|l|}{ Betulaceae } \\
\hline Alnus & + & + & + & + & + & & + & + & + \\
\hline Betula & + & + & + & + & + & + & + & + & + \\
\hline Carpinus & & + & + & & + & & & & \\
\hline Corylus & & + & + & + & & & & & \\
\hline Ostrya & & & + & & & & & & \\
\hline $\begin{array}{l}\text { Ostrya/Carpinus pollen } \\
\text { type }\end{array}$ & & & + & & & & & & \\
\hline Tubela type & & & & & & & & & + \\
\hline \multicolumn{10}{|l|}{ Fagaceae } \\
\hline Fagus & & & + & & & & & & \\
\hline Quercus & & & + & & & & & & \\
\hline \multicolumn{10}{|l|}{ Cannabaceae } \\
\hline Celtis & & & + & & & & & & \\
\hline Humulus & & & & & + & & & & \\
\hline \multicolumn{10}{|l|}{ Ulmaceae } \\
\hline Ulmus & & $p$ & + & & & & & & \\
\hline Zelkova & & & + & & & & & & \\
\hline $\begin{array}{l}\text { Ulmus/Zelkova pollen } \\
\text { type }\end{array}$ & & & $\mathrm{p}$ & & & & & & \\
\hline \multicolumn{10}{|l|}{ Moraceae } \\
\hline Broussonetia & & & & & + & & & & \\
\hline Morus & & & & + & + & & & + & + \\
\hline
\end{tabular}


TABLE 4 (continued).

\begin{tabular}{|c|c|c|c|c|c|c|c|c|c|}
\hline \multirow[b]{2}{*}{ Taxa* $^{*}$} & \multicolumn{3}{|c|}{$55-60^{\circ} \mathrm{N}$} & \multicolumn{4}{|c|}{$60-65^{\circ} \mathrm{N}$} & \multicolumn{2}{|c|}{$65-70^{\circ} \mathrm{N}$} \\
\hline & $\begin{array}{c}\text { Russia } \\
\text { Mag. }\end{array}$ & $\begin{array}{c}\text { AK } \\
\text { Homerian }\end{array}$ & $\begin{array}{c}\text { AK } \\
\text { Seldovian }\end{array}$ & $\begin{array}{c}\text { Russia } \\
\text { Anadry } \\
\text { River }\end{array}$ & $\begin{array}{c}\text { Russia } \\
\text { Mam. } \\
\text { Gora }\end{array}$ & $\begin{array}{c}\text { AK } \\
\text { Porc. R. } \\
90-1\end{array}$ & $\begin{array}{c}\text { Can. } \\
\text { West R. } \\
\text { NWT }\end{array}$ & $\begin{array}{l}\text { Can. } \\
\text { Mary } \\
\text { Sachs }\end{array}$ & $\begin{array}{c}\text { Can } \\
\text { Ballast } \\
\text { Brk. Fm. }\end{array}$ \\
\hline \multicolumn{10}{|l|}{ Urticaceae } \\
\hline Urtica & & & & & + & & & & \\
\hline \multicolumn{10}{|l|}{ Polygonaceae } \\
\hline Polygonum & + & & & + & + & & & & \\
\hline Rumex & & & & & + & & & + & \\
\hline \multicolumn{10}{|l|}{ Amaranthaceae } \\
\hline Chenopodium & & & & & + & & & + & \\
\hline \multicolumn{10}{|l|}{ Cabombaceae } \\
\hline Brasenia & & & & + & + & & & & \\
\hline \multicolumn{10}{|l|}{ Nymphaeaceae } \\
\hline Euryale & & & & & + & & & & \\
\hline Nuphar & & & cf. & & + & & + & & \\
\hline Nymphaea & & & & & + & & & & + \\
\hline \multicolumn{10}{|l|}{ Ceratophyllaceae } \\
\hline Ceratophyllum & & & & & + & & & & \\
\hline \multicolumn{10}{|l|}{ Cercidiphyllaceae } \\
\hline Cercidiphyllum & & + & + & & & & & & \\
\hline \multicolumn{10}{|c|}{ Trochodendraceae } \\
\hline Nordenskioldia & & & + & & & & & & \\
\hline \multicolumn{10}{|l|}{ Aizoaceae } \\
\hline Genus & & & & & & & + & & $?$ \\
\hline \multicolumn{10}{|l|}{ Sesuvium } \\
\hline \multicolumn{10}{|l|}{ Ranunculaceae } \\
\hline Ranunculus & + & & & + & + & & & + & \\
\hline \multicolumn{10}{|l|}{ Magnoliaceae } \\
\hline Liriodendron & & & & & + & & & + & + \\
\hline Magnolia & & & & & + & & & & \\
\hline \multicolumn{10}{|l|}{ Papaveraceae } \\
\hline Corydalis & & & & & + & & & & \\
\hline \multicolumn{10}{|l|}{ Cleomaceae } \\
\hline Cleome & & & & & + & & & + & \\
\hline Polanisia & & & & + & + & & & + & + \\
\hline \multicolumn{10}{|l|}{ Paliurus cf. } \\
\hline Sedum & & & & & & & & + & \\
\hline \multicolumn{10}{|l|}{ Droseraceae } \\
\hline Aldrovanda & & & & + & + & + & & & + \\
\hline \multicolumn{10}{|l|}{ Saxifragaceae } \\
\hline Mitella & & & & & & & & & + \\
\hline Genus undet. & & & & & & & & + & \\
\hline
\end{tabular}


FLETCHER ET AL.: ARCTIC MACROFLORA

TABLE 4 (continued).

\begin{tabular}{|c|c|c|c|c|c|c|c|c|c|}
\hline \multirow[b]{2}{*}{ Taxa* } & \multicolumn{3}{|c|}{$55-60^{\circ} \mathrm{N}$} & \multicolumn{4}{|c|}{$60-65^{\circ} \mathrm{N}$} & \multicolumn{2}{|c|}{$65-70^{\circ} \mathrm{N}$} \\
\hline & $\begin{array}{c}\text { Russia } \\
\text { Mag. }\end{array}$ & $\begin{array}{c}\text { AK } \\
\text { Homerian }\end{array}$ & $\begin{array}{c}\text { AK } \\
\text { Seldovian }\end{array}$ & $\begin{array}{c}\text { Russia } \\
\text { Anadry } \\
\text { River }\end{array}$ & $\begin{array}{l}\text { Russia } \\
\text { Mam. } \\
\text { Gora }\end{array}$ & $\begin{array}{c}\text { AK } \\
\text { Porc. R. } \\
90-1\end{array}$ & $\begin{array}{c}\text { Can. } \\
\text { West R. } \\
\text { NWT }\end{array}$ & $\begin{array}{l}\text { Can. } \\
\text { Mary } \\
\text { Sachs }\end{array}$ & $\begin{array}{c}\text { Can } \\
\text { Ballast } \\
\text { Brk. Fm. }\end{array}$ \\
\hline \multicolumn{10}{|l|}{ Celastraceae } \\
\hline Parnassia & & & & + & & & & & \\
\hline \multicolumn{10}{|l|}{ Hydrangeaceae } \\
\hline Hydrangea & & + & + & & & & & & \\
\hline \multicolumn{10}{|l|}{ Altingiaceae } \\
\hline Liquidambar & & & + & & & & & & \\
\hline \multicolumn{10}{|l|}{ Eucommiaceae } \\
\hline Eucommia & & & + & & & & & & \\
\hline \multicolumn{10}{|l|}{ Platanaceae } \\
\hline Platanus & & & + & & & & & & \\
\hline \multicolumn{10}{|l|}{ Rosaceae } \\
\hline Amelanchier & & + & & + & & & & & \\
\hline Comarum palustre L. type & & & & $?$ & & & & & \\
\hline Crataegus & & + & + & + & & & & & \\
\hline Potentilla & & & & + & + & & + & + & + \\
\hline Prunus padus L. type & $?$ & + & + & + & + & & & & \\
\hline Prunus & & + & + & + & + & & $?$ & & \\
\hline Rubus & + & + & & + & + & & + & + & + \\
\hline Sorbaria & & + & + & & & & & & \\
\hline Spiraea & & + & + & + & & & & & \\
\hline Stephanandra & & & & & + & & & & \\
\hline Genus? & & & & & + & & & & \\
\hline \multicolumn{10}{|l|}{ Fabaceae } \\
\hline Cladrastis & & + & + & & & & & & \\
\hline Pueraria & & & + & & & & & & \\
\hline Genus? & & & & & + & & & & \\
\hline \multicolumn{10}{|l|}{ Euphorbiaceae } \\
\hline Euphorbia & & & & & + & & & & \\
\hline Phyllanthus & & & & & & & & + & + \\
\hline \multicolumn{10}{|l|}{ Empetraceae } \\
\hline Empetrum & & & & $?$ & & & & & \\
\hline \multicolumn{10}{|l|}{ Sapindaceae } \\
\hline Acer & + & + & + & & & & & & \\
\hline \multicolumn{10}{|l|}{ Sabiaceae } \\
\hline Meliosma & & & & + & & & & & \\
\hline \multicolumn{10}{|l|}{ Rhamnaceae } \\
\hline Paliurus cf. & & & & & & & + & + & + \\
\hline Paliurus & & & & & + & & & & \\
\hline \multicolumn{10}{|l|}{ Vitaceae } \\
\hline Ampelopsis & & & & + & & & & & \\
\hline Parthenocissus & & & & & + & & & & \\
\hline Vitis & & & + & + & + & & & & \\
\hline
\end{tabular}


TABLE 4 (continued).

\begin{tabular}{|c|c|c|c|c|c|c|c|c|c|}
\hline \multirow[b]{2}{*}{ Taxa* $^{*}$} & \multicolumn{3}{|c|}{$55-60^{\circ} \mathrm{N}$} & \multicolumn{4}{|c|}{$60-65^{\circ} \mathrm{N}$} & \multicolumn{2}{|c|}{$65-70^{\circ} \mathrm{N}$} \\
\hline & $\begin{array}{c}\text { Russia } \\
\text { Mag. }\end{array}$ & $\begin{array}{c}\text { AK } \\
\text { Homerian }\end{array}$ & $\begin{array}{c}\text { AK } \\
\text { Seldovian }\end{array}$ & $\begin{array}{c}\text { Russia } \\
\text { Anadry } \\
\text { River }\end{array}$ & $\begin{array}{l}\text { Russia } \\
\text { Mam. } \\
\text { Gora }\end{array}$ & $\begin{array}{c}\text { AK } \\
\text { Porc. R. } \\
90-1\end{array}$ & $\begin{array}{c}\text { Can. } \\
\text { West R. } \\
\text { NWT }\end{array}$ & $\begin{array}{l}\text { Can. } \\
\text { Mary } \\
\text { Sachs }\end{array}$ & $\begin{array}{c}\text { Can } \\
\text { Ballast } \\
\text { Brk. Fm. }\end{array}$ \\
\hline Genus? & & & & & & & & + & \\
\hline \multicolumn{10}{|l|}{ Actinidiaceae } \\
\hline Actinidia & & & & & & & + & + & \\
\hline \multicolumn{10}{|l|}{ Malvaceae } \\
\hline Tilia & & & + & & & & & & \\
\hline \multicolumn{10}{|l|}{ Hypericaceae } \\
\hline Hypericum & & & & + & + & + & + & + & + \\
\hline \multicolumn{10}{|l|}{ Violaceae } \\
\hline Viola & & & & + & + & & + & & \\
\hline \multicolumn{10}{|l|}{ Elaeagnaceae } \\
\hline Shepherdia & & + & & & & & & & \\
\hline \multicolumn{10}{|l|}{ Nyssaceae } \\
\hline Nyssa & & & + & & & & & & \\
\hline \multicolumn{10}{|l|}{ Melastomaceae } \\
\hline Nigrella & & & & & + & & & & \\
\hline \multicolumn{10}{|l|}{ Lythraceae } \\
\hline $\begin{array}{l}\text { Decodon globosa (E.M. } \\
\text { Reid) Nikitin type }\end{array}$ & + & & + & + & + & & + & & + \\
\hline $\begin{array}{l}\text { Decodon gibbosus (E.M. } \\
\text { Reid) E.M. Reid in Nikitin } \\
\text { type }\end{array}$ & & & & + & + & + & & & + \\
\hline Hemitrapa & & & + & & & & & & \\
\hline Microdiptera/Mneme type & & & & + & + & & + & + & + \\
\hline Trapa & & & & & + & & & & \\
\hline \multicolumn{10}{|l|}{ Onagraceae } \\
\hline Ludwigia & & & & & & & & + & \\
\hline \multicolumn{10}{|l|}{ Plantaginaceae } \\
\hline Hippuris & + & & & & + & & + & & + \\
\hline \multicolumn{10}{|l|}{ Haloragaceae } \\
\hline Proserpinaca & & & & & + & & & & \\
\hline \multicolumn{10}{|l|}{ Araliaceae } \\
\hline Aralia & + & + & & + & + & & + & + & + \\
\hline Eleutherococcus & + & & & & & & & & \\
\hline Kalopanax & & & + & & & & & & \\
\hline \multicolumn{10}{|l|}{ Cornaceae } \\
\hline Alangium & & & + & & & & & & \\
\hline Cornus & $?$ & + & & + & + & + & & & + \\
\hline \multicolumn{10}{|l|}{ Ericaceae } \\
\hline Ericales indet. & & $\mathrm{p}$ & $\mathrm{p}$ & & & & & & + \\
\hline Andromeda & + & & & + & + & & & + & + \\
\hline Arctostaphylos & & + & & & & & & + & \\
\hline
\end{tabular}


TABLE 4 (continued).

\begin{tabular}{|c|c|c|c|c|c|c|c|c|c|}
\hline \multirow[b]{2}{*}{ Taxa* $^{*}$} & \multicolumn{3}{|c|}{$55-60^{\circ} \mathrm{N}$} & \multicolumn{4}{|c|}{$60-65^{\circ} \mathrm{N}$} & \multicolumn{2}{|c|}{$65-70^{\circ} \mathrm{N}$} \\
\hline & $\begin{array}{c}\text { Russia } \\
\text { Mag. }\end{array}$ & $\begin{array}{c}\text { AK } \\
\text { Homerian }\end{array}$ & $\begin{array}{c}\text { AK } \\
\text { Seldovian }\end{array}$ & $\begin{array}{c}\text { Russia } \\
\text { Anadry } \\
\text { River }\end{array}$ & $\begin{array}{c}\text { Russia } \\
\text { Mam. } \\
\text { Gora }\end{array}$ & $\begin{array}{c}\text { AK } \\
\text { Porc. R. } \\
90-1\end{array}$ & $\begin{array}{c}\text { Can. } \\
\text { West R. } \\
\text { NWT }\end{array}$ & $\begin{array}{c}\text { Can. } \\
\text { Mary } \\
\text { Sachs }\end{array}$ & $\begin{array}{c}\text { Can } \\
\text { Ballast } \\
\text { Brk. Fm. }\end{array}$ \\
\hline Chamaedaphne & & & & + & + & & & + & \\
\hline Kalmia & & & & + & & & & & \\
\hline Rhododendron & & + & & & & & & & \\
\hline Vaccinium & + & + & & + & & & & & \\
\hline Genus? & & & & + & & & & & \\
\hline \multicolumn{10}{|l|}{ Aquifoliaceae } \\
\hline Ilex & & & $\mathrm{p}$ & & & & & & \\
\hline \multicolumn{10}{|l|}{ Primulaceae } \\
\hline Primula (Naumburgia) & & & & $?$ & + & & & & + \\
\hline \multicolumn{10}{|l|}{ Oleaceae } \\
\hline Fraxinus & & & + & & & & & & \\
\hline \multicolumn{10}{|l|}{ Gentianaceae } \\
\hline Menyanthes & + & & & + & + & + & + & & + \\
\hline Nymphoides & & & & & & & & & + \\
\hline \multicolumn{10}{|l|}{ Verbenaceae } \\
\hline Verbena & & & & & & & & + & \\
\hline \multicolumn{10}{|l|}{ Lamiaceae } \\
\hline Ajuga & & & & + & + & & & & \\
\hline Lycopus & & & & & + & & + & & \\
\hline Teucrium & & & & + & + & & & + & + \\
\hline Genus? & & & & & + & & & & \\
\hline \multicolumn{10}{|l|}{ Solanaceae } \\
\hline Solanum/Physalis type & & & & & & & + & + & + \\
\hline \multicolumn{10}{|l|}{ Adoxaceae } \\
\hline Sambucus & & + & & + & + & & + & + & + \\
\hline \multicolumn{10}{|l|}{ Caprifoliaceae } \\
\hline Diervilla & & + & & + & + & & & + & + \\
\hline Lonicera & & + & + & + & & & & & \\
\hline Symphoricarpos & & + & & & & & & & \\
\hline Weigela & & & & + & + & & $?$ & + & + \\
\hline
\end{tabular}

$+=$ macrofossil present.

Seeds, fruits and cones except in Homerian and Seldovian floras, most of which represent foliar remains $p=$ pollen record; in some cases as low as $2 \%$ and trace amounts

"Russ Mag.": Flora (at generic level) from the Marekanskiaya Suite in the Magadan region of east Siberia, Russia (Nikitin, 1979).

"AK Homerian": Plant macrofossils (leaves) and pollen ( $p$ ) from various Homerian age sites in Cook Inlet region of Alaska (Wolfe et al., 1966)

"AK Seldovian": Plant macrofossils (leaves) and pollen ( $p$ ) from various Seldovian age sites in Cook Inlet region

of Alaska (Wolfe et al., 1966; Wolfe and Tanai, 1980).

"Russ Anadyr River": Combination of the fossils listed from the upper and lower N. Pekul'neyveyem suite in the region of the Anadyr

River, East Siberia, Russia (Nikitin, 1979; Baranova and Biske, 1979; Biskeet al.,1972)

"Russ Mam. Gora": Mid-Miocene Mamontova Gora suite, Angara R., east Siberia, Russia (Baranova et al.,1976; Dorofeev, 1969;

Biske, 1975)

"AK Porc. R. 90-1": 16 Ma plant bearing beds beneath basalt in Upper Ramparts of the Porcupine R. in Alaska

"CAN West R. NWT": Mid-Miocene (?) deposits near the West River on northern Canadian mainland (Flora 22)

"CAN Mary Sachs": Mid-Miocene (?) Mary Sachs beds, souther Banks Island, NWT (Flora 10)

"CAN Ballast Brk Fm.": Mid-Miocene (?) Ballast Brook Formation, northern Banks Island (Flora 11a, Fyles et al., 1994) 
is at about the same latitude as the Circle Gravels, Cone Bluff on the Porcupine River, Canyon Village in Alaska, and the Bluefish section in the northern Yukon. The two different floras from Bluefish (Unit $A$ and $B, 9 a$ and $9 b$, respectively) are combined for purposes of the list in Table 3.

The Russian Khapchan floras listed in Table 3 are from the Omoly lowland on the north coast of Siberia. The fossils represent a combination of florules from one section plus those from one other section in the area (Biske, 1975). Farther north on the New Siberian Islands the Nerpichy Sequence is at approximately the same latitude as the Beaufort Formation flora (12a) from Prince Patrick Island. However, the Nerpichy macroflora is very small and not diagnostic, except that it does contain Epipremnum crassum, which Trufanov et al. (1979) believed shows that the deposits could not have formed at a time when permafrost existed in the region. They posit an age of late Oligocene to early Miocene, i.e., older than the Beaufort Formation or any of the other flora discussed here. We include Nerpichy in Table 2 because we believe it may be much younger.

Of all the floras listed in Table 3 only two are radiometrically dated (Lava Camp and Canyon Village). Both are of Clamgulchian age: Lava Camp (Flora 1) at about 5.9 Ma (Turner et al., 1980) and Canyon Village (5) at 6.4 Ma (Fouch et al., 1994; Kunk et al., 1994). The Erman terrestrial sequence from Siberia is interbedded with marine deposits providing independent evidence of its age (Gladenkov, 1979). All of the other floras in the table are apparently dated only by their content of plant fossils.

Several features of Table 3 need mention. First, even though the exact identity of the specimens identified as Paliurus in Appendix 1 and Table 3 is not yet known, it is clear from Dorofeev's (1972) description and illustrations of the Khapchan fossils that what he called Paliurus is the same taxon identified here as Paliurus. Because this taxon occurs in so many of the North American assemblages, we expect it will eventually be discovered in other Mio-Pliocene floras from Russia. The taxon identified as Myrica (Gale) in the table is the same one (with long lateral lobes) seen at a number of North American florules and variously referred to as Myrica eogale or Myrica arctogale (herein).

\section{Mid-Miocene Floras}

Table 4 compares several Russian mid-Miocene floras, with the Homerian and Seldovian of the Cook Inlet Region (leaf floras; Wolfe et al., 1966) and the 'seed' floras from several of the Arctic North American sites discussed here and in Fyles et al. (1994). The Marenkanskiaya Suite (Figure 1) is from the Magadan region. The Anadyr River flora represents the combined floras from the N. Pekul'neyveyem Suite. The Mamontova Gora flora is taken from the list of the middle beds at the classic locality on the Angara River (Figure 1).

As stated above, the list in Table 4 deviates from the primary reference. For example, Aracites globosa is not found in any Russian list. It is a new combination proposed by Bennike (1990), and we believe likely applies to all of the fossils identified as Aracispermum or Aracites johnstruppi (e.g., Bůžek et al., 1985) in the Russian literature. Similarly, we consider Diclidocarya of Russian floras to be synonymous with Microdiptera/Mneme as used here. Pines identified as Pinus montezumae Lamb. are grouped with the Pinus (Pinus) 'three-needle undiff.' in the table. The Prunus padus L. type used in this and following tables refers to small, sculptured stones similar to those of the European bird cherry and includes the small sculptured Prunus stones that Matthews and Ovenden (1990) previously referred to $P$. maximowiczii Rupr.

Azolla occurs in only two of the floras, the Ballast Brook Formation and Mamantova Gora. Pseudotsuga also occurs in only two assemblages. The record from the Ballast Brook Formation is based on a few poorly preserved needles, but there is other evidence that Pseudotsuga grew in the High Arctic in the Paleogene (Obst et al., 1991) and that it survived until the Neogene (see Melville Island, above). Metasequoia occurs at almost all of the sites in the table; Picea does as well.

\section{DISCUSSION}

\section{Powers of Resolution and Different Types of Fossils}

This report concerns primarily plant macrosubfossils such as seeds, fruits, and mosses. Some pollen data are mentioned for several of the sites. What is immediately obvious when one examines each of these lines of evidence is the different power that each has for representing past environmental conditions.

Typically moss floras (Bryophytes) represent local environments to a greater degree than regional environments (Ovenden, 1993). This is why moss floras considered by themselves are at best blunt instruments for reconstructing past regional environments. This also means that when 
TABLE 5. Composition of Native, non-native and extinct genera of plants from selected sites in Siberia and North America.

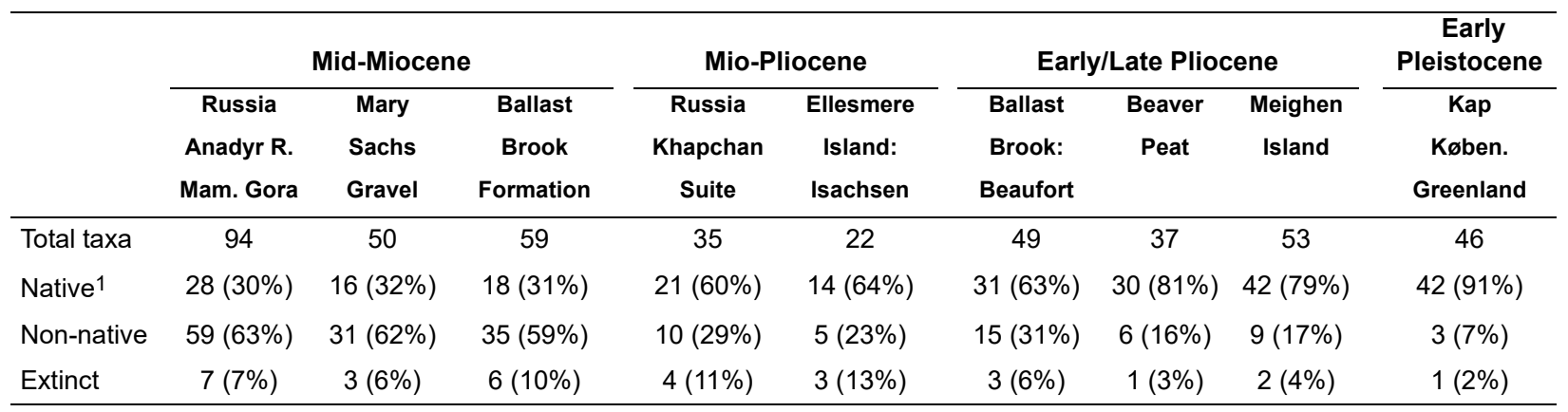

Native $^{1}=$ taxa found in the northern taiga of North America and Russia.

a fossil moss flora is clearly distinct from others in a region or section, the local palaeoenvironmental implications are likely to be more certain than those based on vascular plant assemblages. Based on the modern conditions under which the bryophyte taxa identified from the Isachsen samples (Flora 20) grow, this moss flora represents an in situ forest floor growing within tree limit. Such a definite conclusion with implications for regional conditions is not evident from many of the other moss floras shown in Appendix 1 or in the list in Matthews and Ovenden (1990).

Macrofossils of seeds and fruits of vascular plants provide a different perspective than bryophyte fossils. The richest assemblages come from alluvium. As such they potentially represent a number of different biotopes and more accurately portray regional vegetation and climate than bryophyte fossils. What we have attempted to show here is that even though many of the vascular plant macrofossils are not identified to species they nevertheless provide important information on past climates and environments. Furthermore, unlike most of the bryophyte fossils, some of the vascular fossils are of value for dating and correlation.

One of the most important types of fossils, found in the majority of sites discussed here, is conifer needles. These needles are oftentimes well enough preserved to be sectioned and identified to the species group or subsection level, allowing us to show that some current Asian conifer taxa once were members of the North American Arctic Neogene flora. Because almost every field sample studied to date contains some conifer needles, every one of those samples is a leaf flora, in the strictest sense. Leaf floras comprising angiosperm or non-conifer leaves as we generally think of them, however, are generally rare in the Neogene and Pleistocene Arctic. An extraordinary exception to this is the palaeoflora of Fyles Leaf Beds (17; see Figure 8). Here, leaves are so well-preserved that when we collected them we stored them in a plant press just like collections of modern plants. These leaves provide a unique opportunity to extract late Neogene climatic information from the content of the assemblage, which in the case of Fyles Leaf Beds appear to represent a tundra-like palaeoenvironment. The leaves also provide opportunity to investigate intraspecific variation, stomatal size/density and evidence of insect damage.

In this paper we also attempt preliminary comparison of pollen spectra and plant macrofossil assemblages. Normally pollen provides the most reliable index of regional floras and palaeoenvironmental conditions. In the Arctic some pollen samples portray strikingly different environments from those suggested by the associated macrofossils. The discrepancy is caused partly by under-representation of pine pollen. In Quaternary pollen spectra pine is usually over-represented, and sites on the tundra can yield up to $30 \%$ modern pine pollen. However, in Neogene samples we find sites with a high-representation of pine in the macrofossil record do not have a correspondingly high percentage of pine pollen. We have no explanation for why the situation is different for some of the Neogene samples discussed here. But it must be noted that both the fossil needles and the pollen probably represent extinct species, or at least species with a long-standing adaptation to High Arctic light regimes, and therefore, may have had different reproductive strategies than extant pines.

\section{Phytogeographic Contrasts}

Table 5 compares the taxa listed in Appendix 1 and Table 1 according to whether they are native to the present-day flora, non-native (exotic), or 
extinct and/or of uncertain geographical distribution. It is similar to comparisons attempted by other authors (e.g., Friis, 1975), except in this case the 'native' component is normalized by comparing the list of palaeoflora with the present flora of the North American and Russian northern taiga and tundra zone rather than only the present-day Arctic tundra flora. This makes a substantial difference. For example, the Meighen Island palaeoflora, which would be nearly $90 \%$ 'non-native' or exotic if compared to the current flora at $80^{\circ} \mathrm{N}$, is only $17 \%$ exotic when compared with the flora of a zone extending south to tree line.

The 'extinct' category in the table includes only extinct genera even though it is quite probable that many of the species represented by subfossils of extant genera are also extinct. Therefore, it is expected that the percentages in the extinct category will be much higher when species-level comparisons become possible. Moreover, the number of taxa used for computation of the values shown in Table 5 is low compared with numbers used in comparisons made by Friis (1975) of the north European and western Siberian floras. For example, the most diverse flora in Table 5 has 94 taxa; the most impoverished only 22 . In comparison the Fasterholt flora analysed by Friis (1975) lists 125 taxa. Because of the small sample size available for this study, percentage differences are not likely to be meaningful unless they are large. The following discussion focuses only the most pronounced interregional deviations.

Mid-Miocene floras tend to have almost $60 \%$ or more non-native taxa, compared to $<30 \%$ for Mio-Pliocene floras, and, except for the $30 \%$ exotics in the Beaufort Formation at Ballast Brook (see below), most late Pliocene floras have $20 \%$ or fewer non-natives. Even though the Beaver Pond flora from Ellesmere Island contains a few taxa not seen from Meighen Island, its content of exotic plants is about the same as Meighen Island. Kap København, the youngest of the floras in the table, has a very low count of exotic plants.

Friis (1975) showed a similar trend in European and west Siberian floras. For example, in western Siberia the exotic element in Miocene floras is between $20 \%$ and $50 \%$; for Poland and Germany it's between $40 \%$ and $60 \%$. For the mid- and late Pliocene, the percentage of exotics is $25 \%$ or less.

If the trend to reduction of exotics is a true indication of relative age, then the flora from the Beaufort Formation at Ballast Brook (11b) appears decidedly older than the other Pliocene floras. But it must be remembered that this Banks Island Beaufort Formation flora represents a combination of several florules, the lowest of which are liable to contain rebedded fossils from the mid-Miocene Ballast Brook Formation. Even if only a few Miocene fossils were rebedded into the Pliocene deposit they would significantly inflate the exotic class. Additionally, climatic fluctuations, such as cooling events, during the Pliocene might cause some floras to appear younger than they actually are on the basis of their content of non-natives.

\section{Trees in the High Arctic}

The climate of the Neogene High Arctic was cold enough in winter that trees may not have faced the same problem of 'dark respiration' that appears to have caused deciduous conifers to dominate the Arctic in the Eocene (Basinger, 1991). In spite of this, the deciduous conifer Larix was still more prevalent in the Neogene forests of Arctic North America than it is today - perhaps indicative of the changing trade-offs associated with changing climate.

Further warning of the potential non-analogous environment of the Pliocene High Arctic when compared to modern boreal regions also comes from the Beaufort Formation on Meighen Island. Here, Davies et al. (2014) described a sedimentary feature that is otherwise undocumented within the known Phanerozoic record - extensive cross-bedded woody debris. They propose that the very specific conditions of the Canadian Pliocene High Arctic forested rivers at the time of deposition - the combination of an abundance of woody debris with climatic conditions that reduced decomposition resulted in this curious feature.

The remains of trees in the Arctic have also allowed for analysis of palaeoclimate using qualitative assessments based on ring widths and geochemical methods. For example, Csank et al. (2011a) conducted a detailed analysis of Larix wood from the Beaver Pond locality. They studied both ring widths and stable isotopes in the wood and conclude that during the 250-year life of one tree, the June-July growing season temperatures were $15.8 \pm 5.0^{\circ} \mathrm{C}$ or $11.8 \pm 5.1^{\circ} \mathrm{C}$ warmer than at present and mean annual temperatures $\left(-1.4 \pm 4.0^{\circ} \mathrm{C}\right)$ were $18.3 \pm 4.1^{\circ} \mathrm{C}$ warmer than present. Isotopic analyses allowed them to estimate a relative humidity of between $60 \%$ and $80 \%$ during the growing season. They concluded that their estimates of temperature and relative humidity are typical of modern boreal forest $15-20^{\circ}$ south of the Beaver Pond locality. 


\section{Climate in the Arctic}

The current global picture of the evolution of climate through the Neogene and into the Pleistocene is of cooling (Zachos et al., 2001). This trend was punctuated by short-lived peaks in temperature during 41 ka cycles of low amplitude (Lourens et al., 2010) followed by the Pleistocene state change to $100 \mathrm{ka}$ cycles of high amplitude (Lisiecki, 2010). This general pattern of decreasing temperature punctuated by warmer periods was observed by White et al. (1997a) in the pollen record of Alaska and the Yukon. The sites described here facilitate a comparison of these general trends to what was occurring in the terrestrial North American High Arctic.

Quantitative assessments of High Arctic deposits have primarily focused on Pliocene sites due to the Pliocene's use as an analogue for our near-future climate. In particular, the keystone site, Beaver Pond, has been the subject of considerable, multi-proxy palaeoclimate reconstruction. The methods employed at Beaver Pond include dendroclimatology and isotopic analysis of tree rings, isotopic analysis of molluscs, mutual climate range methods based on arthropods and vascular plants, and specific bacterial membrane lipids. The general agreement of these reconstructions lends support to using these methods in the pre-Quaternary with one exception - beetle-derived winter temperatures (see Fletcher et al., 2019a).

However, the use of many different proxies at sites across the Arctic brings its own complications. It is difficult to ascertain trends or how the estimates herein track changing global averages because many of the proxy schemes reconstruct slightly or entirely different variables. For example, the methods used to reconstruct warm season temperatures include growth season temperature the definition of which varies depending on the organism. In addition, the Arctic sites with climate reconstructions span a wide latitudinal range, so although the latitudinal temperature gradient was shallower during past warm periods, the effect cannot be ignored.

At the broadest level, the current data show a peak in warmth around $15 \mathrm{Ma}$, likely the mid-Miocene Climate Optimum. Temperatures before and after this peak, through to the late Pliocene, remain significantly higher than today. If winter temperatures derived from beetles are discounted due to their probable bias to cold estimates, the higher Neogene warmth is most pronounced during winter. This difference in seasonal distribution of warmth (i.e., much warmer winters compared to present and only moderately warmer summers) may be critical in terms of climate feedbacks due to the important effects of higher winter temperatures on sea ice formation and cloud interactions. Accounting for differences in latitude, the MAT of the Meighen Island sites may reflect the peak warmth of the mid-Piacenzian Warm Period. Fosheim Dome (26) was similarly around $10^{\circ} \mathrm{C}$ warmer than present, but its age is poorly constrained to the late Pliocene or younger. Other late Pliocene or Pleistocene sites are from more southerly locations, i.e., Lost Chicken (2), Ch'ijee's Bluff (8), the Bluefish Exposure (9), and the Cape Deceit Formation, in Alaska and the Yukon; these sites have close to or indistinguishable temperatures compared to modern. The contribution of landscape changes, such as regional uplift seen in Alaska and the Yukon, which could lead to increased continentality at these sites (White et al., 1997a), are also important considerations in disentangling the sometimes intertwined relationship between local and global environmental change. A more detailed comparison of the coupling between Arctic and global climates during the Neogene and into the Pleistocene would be facilitated by the broad-scale application of a single climate reconstruction method where possible, the use of methods that reconstruct identical climate variables, and also the further refinement of site dates by applying absolute dating methods such as terrestrial cosmogenic nuclide dating.

\section{FUTURE RESEARCH}

Despite a long history of research in the North American Arctic, a number of outstanding issues persist. Particularly notable is that comparison of the North American fossil flora and fauna with the Russian fossil materials has been limited. Future studies that allow such comparison may better allow the attribution of some fossils to a species level, where they are currently only identified to genera in this paper, and may result in combinations of species. More importantly, we should at that time be in a better position to test the hypothesized intercontinental commonalties of floras shown in Tables 2, 3, and 4 of this report.

Also key to the synthesis of Eurasian and Arctic North American Neogene palaeontology is new joint field studies at key sites. At this time there are two working groups (known to the authors) working in the Neogene Arctic, PoLAR-FIT (Gosse et al., 2017) focused on the western Arctic, and the Lake El'gygytgyn Drilling Project (Melles et al., 2012; Brigham-Grette et al., 2013) working at Lake 
El'gygytgyn in the east. The addition of Siberian specialists and sites to the PoLAR-FIT group, or the formation of a new research coordination network, would help address this gap.

Only through these kinds of comprehensive investigations will we begin to truly understand the nature of Neogene and late Pleistocene environments in the North American Arctic, when it is possible to compare the same type of fossils from one site to another over the entire region. Strong taxonomic studies form the foundation of more derived studies. For example, a more complete picture of the climate and ecology of the North American High Arctic during the Neogene would lend important data to efforts to understand polar amplification of temperature during our nearest analogue to future climate change, and is key to understanding the evolutionary links between Asian and North American faunas.

\section{ACKNOWLEDGEMENTS}

The authors would like to thank our reviewers, G. Mustoe and an anonymous reviewer, and our editors, M. Pole and A. Bush, for taking the time with this long article in what has been a difficult year for so many. J. Van der Burgh (University of Utrecht), O. Bennike (Geological Survey of Denmark and Greenland), and B. Tiffney (University of California at Santa Barbara) were of help for the identification of fossils. D. and B. Murray (Museum of the North) helped with taxonomic updates. S. Byrne (Paleotec) assisted with management of documentation and photographs. S. Kuzmina (Borissiak Paleontological Institute) helped access and interpret articles in Russian. JVM is also indebted to his colleagues from the USGS/GSC 'team' for their help and support in the field and the office. Funding to complete this work was provided by N.R. through the Canadian Museum of Nature to A.T.; also an Endeavour Research Fellowship (5928-2017), and CAS President's International Fellowship (2019PC0035) to TF. J. Wolfe kindly provided unpublished information on the composition of Neogene floras from the Cook Inlet region. None of the work described here would have been possible without the stimulus, knowledge, and samples contributed by J. Fyles - a friend, a colleague and a man with unending curiosity who was known by many of his Geologic Survey of Canada colleagues as "the last gentleman of the GSC."

\section{DEDICATION}

This work is dedicated to the memory of our two colleagues who passed away during the final stages of preparing this manuscript: Alice Telka, a wonderful friend, mentor, and valuable research partner, and John Matthews Jr., our dear friend and mentor, whose knowledge of the Neogene and Pleistocene Arctic was central to this research.

\section{REFERENCES}

Aalto, M. and Hirvas, H. 1987. Aracites interglacialis, a peat forming extinct plant found from Finnish Lapland. International Union for Quaternary Research XII International Congress Programme with Abstracts, Ottawa, Canada, p. 116.

Ager, T.A., Matthews, J.V., Jr., and Yeend, W. 1994. Pliocene terrace gravels of the ancestral Yukon River near Circle, Alaska: palynology, paleobotany, paleoenvironmental reconstruction and regional correlation. Quaternary International, 22-23:185-206. https://doi.org/10.1016/1040-6182(94)90012-4

Andreev, A., Tarasov, P., Wennrich, V., Raschke, E., Herzschuh, U., Nowaczyk, N.R., BrighamGrette, J., and Melles, M. 2014. Late Pliocene and early Pleistocene vegetation history of northeastern Russian Arctic inferred from the Lake El'gygytgyn pollen record. Climate of the Past, 10(3). https://doi.org/10.5194/cp-10-1017-2014

Andreev, A.A., Tarasov, P.E., Wennrich, V., and Melles, M. 2016. Millennial-scale vegetation changes in the north-eastern Russian Arctic during the Pliocene/Pleistocene transition (2.7$2.5 \mathrm{Ma}$ ) inferred from the pollen record of Lake El'gygytgyn. Quaternary Science Reviews, 147:245-258. https://doi.org/10.1016/j.quascirev.2016.03.030

Andreev, A.A., Tarasov, P.E., Wennrich, V., and Melles, M. 2020. Millennial-scale vegetation history of the north-eastern Russian Arctic during the mid-Pliocene inferred from the Lake El'gygytgyn pollen record. Global and Planetary Change, 186:103111.

https://doi.org/10.1016/j.gloplacha.2019.103111 
Ballantyne, A.P., Rybczynski, N., Baker, P.A., Harington, C.R., and White, D. 2006. Pliocene Arctic temperature constraints from the growth rings and isotopic composition of fossil larch. Palaeogeography, Palaeoclimatology, Palaeoecology, 242(3-4):188-200. https://doi.org/10.1016/j.palaeo.2006.05.016

Ballantyne, A.P., Greenwood, D.R., Sinninghe Damsté, J.S., Csank, A.Z., Eberle, J.J., and Rybczynski, N. 2010. Significantly warmer Arctic surface temperatures during the Pliocene indicated by multiple independent proxies. Geology, 38(7):603-606. https://doi.org/10.1130/g30815.1

Baranova, J.P., Il'jinskaja, I.A., Nikitin, V.P., Pneva, G.P., Fradkina, A.F., and Schvareva, N.Y. 1976. The Miocene of the Mamontova Gora (Stratigraphy and Paleoflora). NAUKA, Moscow. (In Russian)

Baranova, J.P. and Biske, S.F. 1979. Paleogene and Neogene paleoclimates of North-East Asia.186-204. In Shilo, N.A. and Baranova, J.A. (eds.), Continental Tertiary deposits of North-East Asia. NAUKA, Siberian Branch, Novosibirsk. (In Russian)

Bekryaev, R.V., Polyakov, I.V., and Alexeev, V.A. 2010. Role of polar amplification in long-term surface air temperature variations and modern arctic warming. Journal of Climate, 23(14):3888-3906. https://doi.org/10.1175/2010jcli3297.1

Bennike, O. 1990. The Kap København Formation: stratigraphy and palaeobotany of a PlioPleistocene sequence in Peary Land, North Greenland. Greenland Geoscience, 23. Nyt nordisk forlag, København, Denmark.

Biske, S.F. 1975. Paleogene and Neogene in the Far North-East of USSR [Paleogen i neogen krajnego Severo-Vostoka SSSR]. Trudy Instituta geologii i geofizik, 241. Nauka, Novosibirsk, Russia. (In Russian)

Biske, S.F. 1979. Stratigraphy of Quaternary deposits in the extreme Northeast of the USSR. XIV Pacific Science Congress, Committee B, Moscow, USSR, p. 36-37.

Biske, S.F., Baranova, Y.P., and Dort-Gol'ts, Y.E. 1972. New data on the Miocene phytostratigraphy of the northern part of the Anadyr drainage basin and their paleogeographic interpretation. Geographical Problems in Siberia; Scientific reports in the program of the 22nd International Geographical Congress, Novosibirsk, USSR, p. 153-177. (In Russian)

Blake, W., Jr. and Matthews, J.V., Jr. 1979. New data on an interglacial peat deposit near Makinson Inlet, Ellesmere Island, District of Franklin. Geological Survey of Canada, Paper, 79-1A:157-164. https://doi.org/10.4095/104842

Brigham-Grette, J. and Hopkins, D. 1991. The first paleomagnetic evidence from Cape Deceit: a critical late Pliocene-early Pleistocene mammal, plant macrofossil, and beetle locality in central Beringia. Geological Society of America Abstracts with Programs, San Diego, USA, 23, p. A99.

Brigham-Grette, J., Melles, M., Minyuk, P., Andreev, A., Tarasov, P., DeConto, R., Koenig, S., Nowaczyk, N., Wennrich, V., Rosén, P., Haltia, E., Cook, T., Gebhardt, C., Meyer-Jacob, C., Snyder, J., and Herzschuh, U. 2013. Pliocene warmth, polar amplification, and stepped Pleistocene cooling recorded in NE Arctic Russia. Science, 340(6139):1421-1427. https://doi.org/10.1126/science.1233137

Brosgé, W.P. and Reiser, H.N. 1969. Preliminary geologic map of the Coleen Quadrangle, Alaska. Open-File Report 69-25, United States Geologic Survey. https://doi.org/10.3133/ofr6925

Brosgé, W.P., Reiser, H.N., Dutro Jr, J.T., and Churkin Jr, M. 1966. Geologic map and stratigraphic sections, Porcupine River Canyon, Alaska. Open-File Report 66-10, US Geological Survey. https://doi.org/10.3133/ofr6610

Brouwers, E.M. 1994. Late Pliocene paleoecologic reconstructions based on ostracode assemblages from the Sagavanirktok and Gubik Formations, Alaskan North Slope. Arctic, 47:16-33. https://doi.org/10.14430/arctic1268

Bůžek, Č., Kvaček, Z., and Holý, F. 1985. Late Pliocene palaeoenvironment and correlation of the Vildstejn floristic complex within Central Europe. Rozpravy Československé Akademie Věd, Řada Matematických a Prírodních Věd, 95(7):72.

Cande, S.C. and Kent, D.V. 1992. A new geomagnetic polarity time scale for the Late Cretaceous and Cenozoic. Journal of Geophysical Research: Solid Earth, 97(B10):1391713951. https://doi.org/10.1029/92jb01202

Critchfield, W.B. 1986. Hybridization and classification of the white pines (Pinus section Strobus). Taxon, 35(4):647-656. https://doi.org/10.2307/1221606 
Csank, A.Z., Patterson, W.P., Eglington, B.M., Rybczynski, N., and Basinger, J.F. 2011a. Climate variability in the early Pliocene Arctic: Annually resolved evidence from stable isotope values of sub-fossil wood, Ellesmere Island, Canada. Palaeogeography, Palaeoclimatology, Palaeoecology, 308(3-4):339-349. https://doi.org/10.1016/j.palaeo.2011.05.038

Csank, A.Z., Tripati, A.K., Patterson, W.P., Eagle, R.A., Rybczynski, N., Ballantyne, A.P., and Eiler, J.M. 2011b. Estimates of Arctic land surface temperatures during the early Pliocene from two novel proxies. Earth and Planetary Science Letters, 304(3-4):291-299. https://doi.org/10.1016/j.epsl.2011.02.030

Dallimore, S.R. and Matthews, J.V., Jr. 1997. The Mackenzie Delta borehole project. Environmental Studies Research Funds Report, 135, 1 CD ROM, Geological Survey of Canada, Ottawa, Canada.

Davies, N.S., Gosse, J.C., and Rybczynski, N. 2014. Cross-bedded woody debris from a Pliocene forested river system in the High Arctic: Beaufort Formation, Meighen Island, Canada. Journal of Sedimentary Research, 84(1):19-25. https://doi.org/10.2110/jsr.2014.5

Dawson, M.R. and Harington, C. 2007. Boreameryx, an unusual new artiodactyl (Mammalia) from the Pliocene of Arctic Canada and endemism in Arctic fossil mammals. Canadian Journal of Earth Sciences, 44(5):585-592. https://doi.org/10.1139/e06-111

Desmet, P. and Brouillet, L. 2013. Database of Vascular Plants of Canada (VASCAN): a community contributed taxonomic checklist of all vascular plants of Canada, Saint Pierre and Miquelon, and Greenland. PhytoKeys, 25:55-67. https://doi.org/10.3897/phytokeys.25.3100

Dixon, J., Dietrich, J., and McNeil, D.H. 1992. Upper Cretaceous to Pleistocene sequence stratigraphy of the Beaufort-Mackenzie and Banks Island areas, northwest Canada. Geological Survey of Canada Bulletin, 407:1-90. https://doi.org/10.4095/133237

Donoghue, M.J., Bell, C.D., and Li, J. 2001. Phylogenetic patterns in northern hemisphere plant geography. International Journal of Plant Sciences, 162(S6):S41-S52. https://doi.org/10.1086/323278

Dorofeev, P. 1969. The Miocene flora of the Mammoth Mountain on the Aldan River [Miocenovaja flora Mamontovoj Gory na Aldane]. Akademia Nauk CCCP. Botanicheskii Institut VL Komarov, Izdatel'stvo Nauk, Leningrad. (In Russian)

Dorofeev, P. 1972. Tertiary flora of the Omoloi Basin [Istorija flory i rastitel-nosti Evrazii], p. 41112. In Vasil'cenko, I.T. (ed.), The History of the Flora and Vegetation of Eurasia. The Academy of Sciences of the USSR: All Union Botanical Society, USSR. (In Russian)

Dowsett, H.J., Robinson, M.M., Haywood, A.M., Hill, D.J., Dolan, A.M., Stoll, D.K., Chan, W.-L., Abe-Ouchi, A., Chandler, M.A., and Rosenbloom, N.A. 2012. Assessing confidence in Pliocene sea surface temperatures to evaluate predictive models. Nature Climate Change, 2(5):365-371. https://doi.org/10.1038/nclimate1455

Duk-Rodkin, A., Barendregt, R.W., Froese, D.G., Weber, F., Enkin, R., Smith, I.R., Zazula, G.D., Waters, P., and Klassen, R. 2004. Timing and extent of Plio-Pleistocene glaciations in northwestern Canada and east-central Alaska, p. 313-345. In Ehlers, J. and Gibbard, P.L. (eds.), Quaternary Glaciations-Extent and Chronology: Part II: North America. Developments in Quaternary Sciences, 2 Part B, Elsevier. https://doi.org/10.1016/s1571-0866(04)80206-9

Elias, S.A. and Matthews, J.V. 2002. Arctic North American seasonal temperatures from the latest Miocene to the early Pleistocene, based on mutual climatic range analysis of fossil beetle assemblages. Canadian Journal of Earth Sciences, 39(6):911-920. https://doi.org/10.1139/e01-096

Engelmann, G. 1880. Revision of the genus Pinus and description of $P$. elliottii. Proceedings of the Academy of Science of St. Louis, 4:161-193.

Evans, D.J.A., England, J.H., La Farge, C., Coulthard, R.D., Lakeman, T.R., and Vaughan, J.M. 2014. Quaternary geology of the Duck Hawk Bluffs, southwest Banks Island, Arctic Canada: a re-investigation of a critical terrestrial type locality for glacial and interglacial events bordering the Arctic Ocean. Quaternary Science Reviews, 91:82-123. https://doi.org/10.1016/j.quascirev.2014.03.011

Fletcher, T.L., Feng, R., Telka, A.M., Matthews, J.V., and Ballantyne, A. 2017. Floral dissimilarity and the influence of climate in the Pliocene High Arctic: Biotic and abiotic influences on five sites on the Canadian Arctic Archipelago. Frontiers in Ecology and Evolution, 5:19. https://doi.org/10.3389/fevo.2017.00019 
Fletcher, T.L., Csank, A.Z., and Ballantyne, A.P. 2019a. Identifying bias in cold season temperature reconstructions by beetle mutual climatic range methods in the Pliocene Canadian High Arctic. Palaeogeography, Palaeoclimatology, Palaeoecology, 514:672-676. https://doi.org/10.1016/j.palaeo.2018.11.025

Fletcher, T.L., Warden, L., Sinninghe Damsté, J.S., Brown, K.J., Rybczynski, N., Gosse, J.C., and Ballantyne, A.P. 2019b. Evidence for fire in the Pliocene Arctic in response to amplified temperature. Climate of the Past, 15(3):1063-1081. https://doi.org/10.5194/cp-15-1063-2019

Fouch, T.D., Carter, L.D., Kunk, M.J., Smith, C.A.S., and White, J.M. 1994. Miocene and Pliocene lacustrine and fluvial sequences, Upper Ramparts and Canyon village, Porcupine river, east-central Alaska. Quaternary International, 22-23:11-29. https://doi.org/10.1016/1040-6182(94)90004-3

Friis, E.M. 1975. Climatic implications of microcarpological analyses of the Miocene Fasterholt flora, Denmark. Bulletin of the Geological Society of Denmark, 24:179-191.

Friis, E.M. 1985. Angiosperm fruits and seeds from the middle Miocene of Jutland (Denmark). Videnskaberne Selskab Biologiske Skrifter, 24(3):1-165.

Fyles, J.G. 1989. High terrace sediments, probably of Neogene age, west-central Ellesmere Island, Northwest Territories. Geological Survey of Canada, Paper 89-1D:101-104. https://doi.org/10.4095/126702

Fyles, J.G. 1990. Beaufort Formation (late Tertiary) as seen from Prince Patrick Island, Arctic Canada. Arctic, 43(4):393-403.

Fyles, J.G., Marincovich, L., Jr., Matthews, J.V., Jr., and Barendregt, R. 1991. Unique mollusc find in the Beaufort Formation (Pliocene) on Meighen Island, Arctic Canada. Geologic Survey of Canada Current Research B, 91:105-112.

Fyles, J.G., Hills, L.V., Matthews, J.V., Jr., Barendregt, R., Baker, J., Irving, E., and Jetté, H. 1994. Ballast Brook and Beaufort Formations (late Tertiary) on Northern Banks Island, Arctic Canada. Quaternary International, 22:141-171. https://doi.org/10.1016/1040-6182(94)90010-8

Fyles, J.G., McNeil, D.H., Barendregt, J.V., Marincovich, L.J., Brouwers, E.M., Bednarski, J., Brigham-Grette, J., Ovenden, L.E., Miller, K.G., Baker, J., and Irving, E. 1998. Geology of Hvitland Beds (late Pliocene), White Point Lowland, Ellesmere Island, Northwest Territories. Bulletin of the Geological Survey of Canada, 512:i-35. https://doi.org/10.4095/209577

Gladenkov, A.Y., Oleinik, A.E., Marincovich Jr., L., and Barinov, K.B. 2002. A refined age for the earliest opening of Bering Strait. Palaeogeography, Palaeoclimatology, Palaeoecology, 183(3-4):321-328. https://doi.org/10.1016/S0031-0182(02)00249-3

Gladenkov, Y.B. 1979. Comparison of late Cenozoic molluscan assemblages in northern regions of the Atlantic and Pacific Oceans. International Geology Review, 21(8):880-890. https://doi.org/10.1080/00206818209467134

Gosse, J.C., Ballantyne, A.P., Barker, J.D., Csank, A.Z., Fletcher, T.L., Grant, G.W., Greenwood, D.R., MacPhee, R.D., and Rybczynski, N. 2017. PoLAR-FIT: Pliocene Landscapes and Arctic Remains-Frozen in Time. Geoscience Canada, 44(1):47-54. https://doi.org/10.12789/geocanj.2017.44.116

Graebner, P. 1907. Revision der Voss schen Coniferen-Nomenklatur. Mitteilungen der Deutschen Dendrologischen Gesellschaft, 93:66-69. (In German)

Gregor, H.J. and Bogner, J. 1984. Fossile Araceen Mitteleuropas und ihre rezenten Vergleichsformen. Documenta naturae, 19:1-12. (In German)

Guthrie, R.D. and Matthews, J.V. 1971. The Cape Deceit fauna-early Pleistocene mammalian assemblage from the Alaskan Arctic. Quaternary Research, 1(4):474-510. https://doi.org/10.1016/0033-5894(71)90060-3

Haywood, A.M., Dowsett, H.J., and Dolan, A.M. 2016. Integrating geological archives and climate models for the mid-Pliocene warm period. Nature Communications, 7(10646):1-14. https://doi.org/10.1038/ncomms 10646

Hills, L. 1969. Beaufort Formation, northwestern Banks Island, District of Franklin. Geological Survey of Canada, Paper, 69(1):204-207. https://doi.org/10.4095/106000

Hills, L. 1975. Late Tertiary floras Arctic Canada: an interpretation. Proceedings of Circumpolar Conference on Northern Ecology, Ottawa, Canada, 1, p. 2.

Hills, L., Klovan, J., and Sweet, A. 1974. Juglans eocinerea n. sp., Beaufort Formation (Tertiary), southwestern Banks Island, Arctic Canada. Canadian Journal of Botany, 52(1):65-90. https://doi.org/10.1139/b74-011 
Hodgson, D.A., Vincent, J.-S., and Fyles, J.G. 1984. Quaternary geology of central Melville Island, Northwest Territories. Geological Survey of Canada Paper, 83-16:1-25. https://doi.org/10.4095/119784

Hopkins, D., Matthews, J., Wolfe, J., and Silberman, M. 1971. A Pliocene flora and insect fauna from the Bering Strait region. Palaeogeography, Palaeoclimatology, Palaeoecology, 9(3):211231. https://doi.org/10.1016/0031-0182(71)90032-0

Kaufman, D.S. 1992. Aminostratigraphy of Pliocene-Pleistocene high-sea-level deposits, Nome coastal plain and adjacent nearshore area, Alaska. Geological Society of America Bulletin, 104(1):40-52. https://doi.org/10.1130/0016-7606(1992)104<0040:aopphs>2.3.co;2

Kaufman, D.S. and Brigham-Grette, J. 1993. Aminostratigraphic correlations and paleotemperature implications, Pliocene-Pleistocene high-sea-level deposits, northwestern Alaska. Quaternary Science Reviews, 12(1):21-33. https://doi.org/10.1016/0277-3791(93)90046-o

Kay, P.A. 1978. Dendroecology in Canada's forest-tundra transition zone. Arctic and Alpine Research, 10(1):133-138. https://doi.org/10.2307/1550662

Kim, Y.-D. and Kim, S.-H. 1999. Phylogeny of Weigela and Diervilla (Caprifoliaceae) based on nuclear rDNA ITS sequences: biogeographic and taxonomic implications. Journal of Plant Research, 112(3):331-341. https://doi.org/10.1007/PL00013887

Klassen, R.A., Matthews, J.V., Jr., Mott, R.J., and Thompson, F.J. 1988. The stratigraphic and paleobotanical record of Interglaciation in the Wabush region of western Labrador. Climatic Fluctuations and Man 3, Annual Meeting of the Canadian Committee on Climatic Fluctuations, Ottawa, Canada, p. 24-26.

Kuc, M. and Hills, L.V. 1971. Fossil mosses, Beaufort Formation (Tertiary), Northwestern Banks Island, Western Canada Arctic. Canadian Journal of Botany, 49(7):1089-1094. https://doi.org/10.1139/b71-156

Kunk, M.J., Rieck, H., Fouch, T.D., and Carter, L.D. 1994. ${ }^{40} \mathrm{Ar} /{ }^{39} \mathrm{Ar}$ age constraints on Neogene sedimentary beds, Upper Ramparts, half-way Pillar and Canyon village sites, Porcupine river, east-central Alaska. Quaternary International, 22-23:31-42. https://doi.org/10.1016/1040-6182(94)90005-1

Lambert, A.B. 1832. Description of the genus Pinus, with directions relative to the cultivation, and remarks on the uses of the several species: also, descriptions of many other new species of the family of Coniferae, Volume 1 of 3 . Weddell, London.

Lisiecki, L.E. 2010. Links between eccentricity forcing and the 100,000-year glacial cycle. Nature Geoscience, 3(5):349-352. https://doi.org/10.1038/ngeo828

Little, E.L. and Critchfield, W.B. 1969. Subdivisions of the Genus Pinus (pines). Miscellaneous Publication, 1144:1-51, US Forest Service, Washington DC.

Lourens, L.J., Becker, J., Bintanja, R., Hilgen, F.J., Tuenter, E., van de Wal, R.S.W., and Ziegler, M. 2010. Linear and non-linear response of late Neogene glacial cycles to obliquity forcing and implications for the Milankovitch theory. Quaternary Science Reviews, 29(1):352-365. https://doi.org/10.1016/j.quascirev.2009.10.018

Manchester, S.R. 1987. The fossil history of the Juglandaceae. Monographs in Systematic Botany from the Missouri Botanical Garden, 21:1-137. https://doi.org/10.5962/bhl.title.154222

Marincovich, L., Jr. and Gladenkov, A.Y. 2001. New evidence for the age of Bering Strait. Quaternary Science Reviews, 20(1-3):329-335. https://doi.org/10.1016/S0277-3791(00)00113-X

Marincovich, L., Jr., Powell, C.L., McNeil, D.H., and Miller, K.G. 1991. Comment and Reply on "High-latitude application of 87Sr/86Sr: Correlation of Nuwok beds on North Slope, Alaska, to standard Oligocene chronostratigraphy." Geology, 19(5):537-539. https://doi.org/10.1130/0091-7613(1991)019<0537:carohl>2.3.co;2

Matthews, J.V., Jr. 1987. Plant macrofossils from the Neogene Beaufort Formation on Banks and Meighen islands, District of Franklin. Current Research Part A. Geological Survey of Canada 87-1A:73-87. https://doi.org/10.4095/122513

Matthews, J.V., Jr. 1989. New information on the flora and age of the Beaufort Formation, Arctic Archipelago, and related Tertiary deposits in Alaska. Geological Survey of Canada, Current Research, 89-1D:105-111. https://doi.org/10.4095/126704 
Matthews, J.V., Jr. and Fyles, J.G. 2000. Late Tertiary plant and arthropod fossils from the highterrace sediments on Fosheim Peninsula, Ellesmere Island, Nunavut, p. 295-317. In Garneau, M., and Alt, B.T. (eds.), Environmental response to climate change in the Canadian High Arctic, 529, Geological Survey of Canada, Bulletin. https://doi.org/10.4095/211969

Matthews, J.V., Jr. and Ovenden, L.E. 1990. Late Tertiary plant macrofossils from localities in Arctic/Subarctic North America: a review of the data. Arctic, 43(4):364-392. https://doi.org/10.14430/arctic1631

Matthews, J.V., Jr. and Telka, A. 1997. Insect fossils from the Yukon, p. 911-962, Insects of the Yukon, Biological Survey of Canada (Terrestrial Arthropods), Ottawa, Ontario.

Matthews, J.V., Jr., Hughes, O.L., and Schweger, C.E. 1987. Stop 30: Twelvemile Bluff exposure, p. 95-98. In Smith, C.A.S. and Morrison, S.R. (eds.), Guide Book A-20 (a) and (b), Quaternary research in Yukon. INQUA IIX Congress, National Research Council of Canada, Ottawa, Canada.

Matthews, J., Jr., Schweger, C., and Janssens, J. 1990a. The last (Koy-Yukon) interglaciation in the northern Yukon: evidence from Unit 4 at Ch'ijee's Bluff, Bluefish Basin. Géographie physique et Quaternaire, 44(3):341-362. https://doi.org/10.1016/1040-6182(91)90042-m

Matthews, J.V., Jr., Ovenden, L.E., and Fyles, J.G. 1990b. Plant and insect fossils from the late Tertiary Beaufort Formation on Prince Patrick Island, NWT, p. 105-139. In Harington, C.R. (ed.), Canada's missing dimension: science and history in the Canadian Arctic Islands, 1, Canadian Museum of Nature, Ottawa, Canada. https://doi.org/10.5962/bhl.title.52115

Matthews, J.V., Jr., Westgate, J.A., Ovenden, L., Carter, L.D., and Fouch, T. 2003. Stratigraphy, fossils, and age of sediments at the upper pit of the Lost Chicken gold mine: new information on the late Pliocene environment of east central Alaska. Quaternary Research, 60(1):9-18. https://doi.org/10.1016/s0033-5894(03)00087-5

Matthews, J.V., Jr., Telka, A.M., and Kuzmina, S.A. 2019. Late Neogene insect and other invertebrate fossils from Alaska and Arctic/Subarctic Canada. Invertebrate Zoology, 16(2):126-153. https://doi.org/10.15298/invertzool.16.2.03

McCourt, G.H. 1982. Quaternary palynology of the Bluefish Basin, northern Yukon Territory. Unpublished MSc Thesis, University of Alberta, Edmonton, USA.

McDougall, K. 1995. Age of the Fishcreekian Transgression. PALAIOS, 10(3):199-220. https://doi.org/10.2307/3515253

McKown, A.D., Stockey, R.A., and Schweger, C.E. 2002. A new species of Pinus subgenus Pinus subsection Contortae from Pliocene sediments of Ch'ijee's Bluff, Yukon Territory, Canada. International Journal of Plant Sciences, 163(4):687-697. https://doi.org/10.1086/340425

McNeil, D.H. and Miller, K.G. 1990. High-latitude application of $87 \mathrm{Sr} / 86 \mathrm{Sr}$ : correlation of Nuwok beds on North Slope, Alaska, to standard Oligocene chronostratigraphy. Geology, 18(5):415418. https://doi.org/10.1130/0091-7613(1990)018<0415:hlaoss>2.3.co;2

Meades, S., Hay, S.G., and Brouillet, L. 2000. Annotated Checklist of the Vascular Plants of Newfoundland and Labrador, 2009. Published in association with A Digital Flora of Newfoundland and Labrador Vascular Plants, Sault Ste. Marie, Ontario.

Melles, M., Brigham-Grette, J., Minyuk, P.S., Nowaczyk, N.R., Wennrich, V., DeConto, R.M., Anderson, P.M., Andreev, A.A., Coletti, A., and Cook, T.L. 2012. 2.8 million years of Arctic climate change from Lake El'gygytgyn, NE Russia. Science, 337(6092):315-320. https://doi.org/10.1126/science.1222135

Mendell, E. 2006. Using fossil trees to estimate paleoclimate of Banks Island, Arctic Canada and the effects of modern climate change on the Arctic. Proceedings of the 19th Annual Keck Symposium in Geology, Amherst, USA, p. 20-23. https://doi.org/10.18277/akrsg.2006.19

Miller, C.N. and Ping, L. 1994. Structurally preserved larch and spruce cones from the Pliocene of Alaska. Quaternary International, 22-23:207-214. https://doi.org/10.1016/1040-6182(94)90013-2

Mitchell, W.T., Rybczynski, N., Schröder-Adams, C., Hamilton, P.B., Smith, R., and Douglas, M. 2016. Stratigraphic and paleoenvironmental reconstruction of a mid-Pliocene fossil site in the High Arctic (Ellesmere Island, Nunavut): evidence of an ancient peatland with beaver activity. Arctic, 69(2):185-204. https://doi.org/10.14430/arctic4567

Murray, A.M., Cumbaa, S.L., Harington, C.R., Smith, G.R., and Rybczynski, N. 2009. Early Pliocene fish remains from Arctic Canada support a pre-Pleistocene dispersal of percids (Teleostei: Perciformes). Canadian Journal of Earth Sciences, 46(7):557-570. https://doi.org/10.1139/e09-037 
Newmaster, S.G., Lehela, A., Oldham, M.J., Uhlig, P.W.C., and McMurray, S. 1998. Ontario Plant List Forest Information Paper No. 123, 1-550, Ontario Forest Research Institute, Sault Ste. Marie, Ontario.

Nikitin, V. 2007. Paleogene and Neogene strata in Northeastern Asia: paleocarpological background. Russian Geology and Geophysics, 48(8):675-682. (In Russian)

Nikitin, V.P. [Никитин, Вадим Петрович] 2006. Палеокарпология и стратиграфия палеогена и неогена Азиатской России (Palaeocarpology and Stratigraphy of the Palaeogene and the Neogene Strata in Asian Russia - In Russian.) Издательство Академии “Гео” (Academy Publishing House "Geо”), новосибирск (Novosibirsk).

Obst, J.R., McMillan, N.J., Blanchette, R.A., Christensen, D.J., Faix, O., Han, J., Kuster, T., Landucci, L., Newman, R., and Pettersen, R. 1991. Characterization of Canadian Arctic fossil woods, p. 123-146. In Christie, R.L. and McMillan, N.J. (eds.), Tertiary Fossil Forests of the Geodetic Hills Axel Heiberg Island, Arctic Archipelago. Geological Survey of Canada Bulletin, 403, Canadian Government Publishing Centre, Ottawa, Ontario. https://doi.org/10.4095/131951

Ovenden, L. 1993. Late Tertiary mosses of Ellesmere Island. Review of Palaeobotany and Palynology, 79(1-2):121-31. https://doi.org/10.1016/0034-6667(93)90042-s

Pedersen, V.K., Larsen, N.K., and Egholm, D.L. 2019. The timing of fjord formation and early glaciations in North and Northeast Greenland. Geology, 47(7):682-686. https://doi.org/10.1130/g46064.1

Plint, T., Longstaffe, F.J., Ballantyne, A., Telka, A., and Rybczynski, N. 2020. Evolution of woodcutting behaviour in early Pliocene beaver driven by consumption of woody plants. Scientific Reports, 10(1):13111. https://doi.org/10.1038/s41598-020-70164-1

Plumley, P. and Vance, M. 1988. Porcupine River basalt field, northeast Alaska: age, paleomagnetism and tectonic significance. EOS Abstracts, Transactions of the American Geophysical Union, Baltimore, USA, 69, p. 1458.

Porter, L. 1988. Late Pleistocene fauna of Lost Chicken Creek, Alaska. Arctic, 41(4):303-313. https://doi.org/10.14430/arctic1737

Porter, T.J. 2014. A similar-to-modern Pliocene climate in continental Alaska and Yukon recorded by multiple water isotope proxies: plant lipids, wood cellulose and hydrated glass shards. Geological Society of America Annual Meeting Vancouver, Canada, Abstracts with Programs, 46, p. 807.

Reid, C. and Reid, E.M. 1915. The Pliocene floras of the Dutch-Prussian border. Mededeelingen van de Rijksopsporing van Delfstoffen, 6(6):178.

Repenning, C.A. 2003. Mimomys in North America, Chapter 17, p. 469-512, Bulletin of the American Museum of Natural History, 279. https://doi.org/10.1206/0003-0090(2003)279<0469:C>2.0.CO;2

Repenning, C.A. and Brouwers, E.M. 1992. Late Pliocene-early Pleistocene ecologic changes in the Arctic Ocean borderland. U. S. Geological Survey Bulletin, 2036:1-37. https://doi.org/10.3133/b2036

Riediger, C.L., Bustin, R., and Rouse, G. 1984. New evidence for the chronology of the Eurekan Orogeny from south-central Ellesmere Island. Canadian Journal of Earth Sciences, 21(11):1286-1295. https://doi.org/10.1139/e84-133

Rybczynski, N. 2008. Woodcutting behavior in beavers (Castoridae, Rodentia): estimating ecological performance in a modern and a fossil taxon. Paleobiology, 34(3):389-402. https://doi.org/10.1666/06085.1

Rybczynski, N., Gosse, J.C., Richard Harington, C., Wogelius, R.A., Hidy, A.J., and Buckley, M. 2013. Mid-Pliocene warm-period deposits in the High Arctic yield insight into camel evolution. Nature Communications, 4(1550):1-9. https://doi.org/10.1038/ncomms2516

Schorn, H.E. 1994. A preliminary discussion of fossil larches (Larix, Pinaceae) from the Arctic. Quaternary International, 22-23:173-183. https://doi.org/10.1016/1040-6182(94)90011-6

Scoggan, H.J. 1978-1979. The Flora of Canada. National Museum of Natural Sciences Publications in Botany, 1-4. National Museums of Canada, Ottawa. https://doi.org/10.5962/bhl.title.122890

Sher, A. 1986. Olyorian land mammal age of northeastern Siberia. Palaeontographica Italica, 74:97-112.

Sher, A., Kaplina, T., Giterman, R., Lozhkin, A., Arkhangelov, A., Kiselyov, S., Kouznetsov, Y.V., Virina, E., and Zazhigin, V. 1979. Late Cenozoic of the Kolyma lowland. XIV Pacific Science Congress, Tour Guide XI, Khabarovsk, USSR, p. 1-116. 
Storer, J.E. 2003. The Eastern Beringian vole Microtus deceitensis (Rodentia, Muridae, Arvicolinae) in late Pliocene and early Pleistocene faunas of Alaska and Yukon. Quaternary Research, 60(1):84-93. https://doi.org/10.1016/S0033-5894(03)00067-X

Takhtajan, A.L. (ed.) 1982. Magnoliophyta Fossilia U.R.S.S. Volume 2, Ulmaceae-Betulaceae. Izdat. Nauka, Leningrad. (In Russian)

Tedford, R.H. and Harington, C.R. 2003. An Arctic mammal fauna from the early Pliocene of North America. Nature, 425(6956):388-390. https://doi.org/10.1038/nature01892

Thorson, R.M. and Dixon, E.J. 1983. Alluvial history of the Porcupine River, Alaska: role of glacial-lake overflow from northwest Canada. Geological Society of America Bulletin, 94(5):576-589. https://doi.org/10.1130/0016-7606(1983)94<576:ahotpr>2.0.co;2

Tiffney, B.H. 1981. Fruits and seeds of the Brandon lignite, VI. Microdiptera (Lythraceae). Journal of the Arnold Arboretum, 62(4):487-516. https://www.jstor.org/stable/43782097

Tiffney, B.H. and Barghoorn, E.S. 1976. Fruits and seeds of the Brandon lignite. I. Vitaceae. Review of Palaeobotany and Palynology, 22(3):169-191. https://doi.org/10.1016/0034-6667(76)90001-4

Tozer, E. 1956. Geological reconnaissance, Prince Patrick, Eglinton and western Melville Islands, Arctic Archipelago, Northwest Territories. Geological Survey of Canada Paper, 555:1-32. https://doi.org/10.4095/101290

Tralau, H. 1959. Extinct aquatic plants of Europe. Botaniska Notiser, 112(4):385-406.

Trufanov, G.V., Belousov, K.N., and Vakulenko, A.S. 1979. Some data about stratigraphy of Cenozoic deposits of New Siberian Islands, p. 30-39. In Shilo, N.A. and Baranova, J.P. (eds.), Continental Tertiary deposits of North-East Asia, NAUKA, Siberian Branch, Novosibirsk.

Turner, D.L., Triplehorn, D.M., Naeser, C.W., and Wolfe, J.A. 1980. Radiometric dating of ash partings in Alaskan coal beds and upper Tertiary paleobotanical stages. Geology, 8:92-96. https://doi.org/10.1130/0091-7613(1980)8<92:rdoapi>2.0.co;2

Vincent, J.-S. 1990. Late Tertiary and early Pleistocene deposits and history of Banks Island, southwestern Canadian Arctic Archipelago. Arctic, 43:339-363. https://doi.org/10.14430/arctic1630

Wang, X., Rybczynski, N., Harington, C.R., White, S.C., and Tedford, R.H. 2017. A basal ursine bear (Protarctos abstrusus) from the Pliocene High Arctic reveals Eurasian affinities and a diet rich in fermentable sugars. Scientific Reports, 7(1):17722. https://doi.org/10.1038/s41598-017-17657-8

Westgate, J., Schweger, C., Sandhu, A., Morlan, R., and Matthews, J., Jr. 1995. Tephrochronological, palaeomagnetic and palaeoenvironmental studies of late Cenozoic deposits in the northern Yukon, Canada. XIV International Union for Quaternary Research (INQUA) Congress, Abstracts, Berlin, Germany, p. 296.

Wheeler, E.A. and Arnette, C.G. 1994. Identification of Neogene woods from Alaska-Yukon. Quaternary International, 22-23:91-102. https://doi.org/10.1016/1040-6182(94)90008-6

White, J.M. and Ager, T.A. 1994. Palynology, paleoclimatology and correlation of middle Miocene beds from Porcupine River (locality 90-1), Alaska. Quaternary International, 22-23:43-77. https://doi.org/10.1016/1040-6182(94)90006-X

White, J.M., Ager, T.A., Adam, D.P., Leopold, E.B., Liu, G., Jetté, H., and Schweger, C.E. 1997a. An 18 million year record of vegetation and climate change in northwestern Canada and Alaska: tectonic and global climatic correlates. Palaeogeography, Palaeoclimatology, Palaeoecology, 130(1):293-306. https://doi.org/10.1016/S0031-0182(96)00146-0

White, J.M., Ager, T.A., Adam, D.P., Leopold, E.B., Liu, G., Jettè, H., and Schweger, C.E. 1997b. Neogene and Quaternary selected palynological data from Yukon and adjacent Northwest Territories and Alaska. Geological Survey of Canada, Open File 3557, 1-43. https://doi.org/10.4095/209379

White, J.M., Ager, T.A., Adam, D.P., Leopold, E.B., Liu, G., Jetté, H., and Schweger, C.E. 1999. Neogene and Quaternary quantitative palynostratigraphy and paleoclimatology from sections in Yukon and adjacent Northwest Territories and Alaska. Geological Survey of Canada, Bulletin, 543:30. https://doi.org/10.4095/210923

Williams, C.J., Mendell, E.K., Murphy, J., Court, W.M., Johnson, A.H., and Richter, S.L. 2008. Paleoenvironmental reconstruction of a middle Miocene forest from the western Canadian Arctic. Palaeogeography, Palaeoclimatology, Palaeoecology, 261:160-176.

https://doi.org/10.1016/j.palaeo.2008.01.014 
Williams, J.R. 1962. Geologic reconnaissance of the Yukon Flats district, Alaska. United States Geological Survey Bulletin, 1111-H:289-330. https://doi.org/10.3133/b1111h

Wilson, R., Greenwood, D., and Basinger, J. 2006. Fossil remains of the walnut family (Juglandaceae) from the Eocene fossil forests of Axel Heiberg Island, Canadian High Arctic (poster). Canadian Botanical Association meeting, Concordia University, Montreal.

Witkowski, C., Gupta, N.S., Yang, H., Leng, Q.I.N., Williams, C.J., Briggs, D.E.G., and Summons, R.E. 2012. Molecular preservation of Cenozoic conifer fossil Largerstätten from Banks Island, The Canadian Arctic. PALAIOS, 27(5/6):279-287. https://doi.org/10.2110/palo.2011.p11-031r

Wolfe, J.A. 1994. An analysis of Neogene climates in Beringia. Palaeogeography, Palaeoclimatology, Palaeoecology, 108(3-4):207-216. https://doi.org/10.1016/0031-0182(94)90234-8

Wolfe, J.A., Hopkins, D., and Leopold, E.B. 1966. Tertiary stratigraphy and paleobotany of the Cook Inlet region, Alaska. U. S. Geological Survey Professional Paper, 398-A:1-29.

Wolfe, J.A. and Tanai, T. 1980. The Miocene Seldovia point flora from the Kenai group, Alaska. U.S. Geological Survey Professional Paper, 1105:1-52. https://doi.org/10.3133/pp1105

Zachos, J., Pagani, M., Sloan, L., Thomas, E., and Billups, K. 2001. Trends, rhythms, and aberrations in global climate $65 \mathrm{Ma}$ to present. Science, 292(5517):686. https://doi.org/10.1126/science.1059412

Zachos, J.C., Dickens, G.R., and Zeebe, R.E. 2008. An early Cenozoic perspective on greenhouse warming and carbon-cycle dynamics. Nature, 451(7176):279-283. https://doi.org/10.1038/nature06588

Zagwijn, W. 1990. Subtropical relicts in the Pliocene flora of Brunssum (The Netherlands). Geologie en Mijnbouw, 69(3):219-225.

Zazula, G.D., Duk-Rodkin, A., Schweger, C.E., and Morlan, R.E. 2004. Late Pleistocene chronology of glacial Lake Old Crow and the north-west margin of the Laurentide Ice Sheet, p. 347-362. In Ehlers, J. and Gibbard, P.L. (eds.), Developments in Quaternary Sciences, 2, Elsevier, The Netherlands. https://doi.org/10.1016/s1571-0866(04)80207-0

Zubakov, V.A. and Borzenkova, I.I. 1990. Global Palaeoclimate of the late Cenozoic, 12. Elsevier, Amsterdam. 


\section{APPENDIX 1.}

Plant macrofossils from various Alaskan and northern Canadian sites. Appendix 1 and 2 are included in a zipped file for download at https://palaeo-electronica.org/content/2021/3274-arcticmacroflora.

\section{APPENDIX 2.}

Includes all tables in spreadsheet format. Appendix 1 and 2 are included in a zipped file for download at https://palaeo-electronica.org/content/2021/3274-arctic-macroflora.

TABLE 1. Comparison of selected pollen spectra from Canadian Neogene Arctic.

TABLE 2. Comparison of late Pliocene and early Pleistocene Florules from Eastern Siberia, Alaska and northern Canada.

TABLE 3. Comparison of late Miocene and early Pliocene Florules from Eastern Siberia, Alaska, and northern Canada.

TABLE 4. Comparison of mid-Miocene and early late Miocene Florules from Eastern Siberia, Alaska, and northern Canada.

TABLE 5. Composition of Native, non-native and extinct genera of plants from selected sites in Siberia and North America. 